\title{
Studies in Macrolide Antibiotic Synthesis: The Role of Tethered Alkoxides in Titanium Alkoxide-mediated Regioselective Reductive Coupling Reactions
}

Adilah B. Bahadoor and Glenn C. Micalizio*

Department of Chemistry, Yale University, New Haven, CT 06520

E-mail: glenn.micalizio@yale.edu

SUPPORTING INFORMATION-1: 
General. All reactions were conducted in flame dried glassware under nitrogen using anhydrous solvents. Toluene was dried by distillation over sodium benzophenone ketyl. Dichloromethane, tetrahydrofuran and diethylether were used after passing through activated alumina columns. Methyl sulfoxide was purchased from Aldrich Chemical Company in Sure/Seal ${ }^{\mathrm{TM}}$ containers and used as received. Triethylamine was dried by distillation over $\mathrm{CaH}_{2}$. All chiral aldehydes were obtained from a Swern or Dess-Matin oxidation of the corresponding primary alcohol and used without purification. All other commercially available reagents were used as received.

${ }^{1} \mathrm{H}$ NMR data were recorded at $500 \mathrm{MHz}$ or $400 \mathrm{MHz}$ using a Bruker AM-500, a Bruker Avance DPX-500 or a Bruker AM-400 instrument. ${ }^{1} \mathrm{H}$ NMR chemical shifts are reported relative to residual $\mathrm{CHCl}_{3}(7.27 \mathrm{ppm})$ or $\mathrm{C}_{6} \mathrm{H}_{6}(7.16 \mathrm{ppm}) .{ }^{13} \mathrm{C}$ NMR data were recorded at $126 \mathrm{MHz}$ using a Bruker AM-500 or a Bruker Avance DPX-500 instrument. ${ }^{13} \mathrm{C}$ chemical shifts are reported relative to the central line of $\mathrm{CDCl}_{3}(77.23 \mathrm{ppm})$ or $\mathrm{C}_{6} \mathrm{D}_{6}$ (128.00 ppm). Infrared spectra were recorded using a Midac Spectrometer M-series. Low resolution mass spectrometry was performed on a Waters Micromass ${ }^{\circledR} \mathrm{ZQ}^{\mathrm{TM}}$ instrument using electrospray ionization (EI). Optical rotations were measured on Perkin Elmer Model 341 polarimeter using a $1 \mathrm{~mL}$ capacity micro cell with a $10 \mathrm{~cm}$ path length.

Chromatographic purifications were performed using $60 \AA, 35-75 \mu \mathrm{m}$ particle size silica gel from Silicycle. All compounds purified by chromatography were sufficiently pure for use in further experiments, unless indicated otherwise.

For all reductive coupling reactions, the major diastereomer was tentatively assigned as the product derived from net Felkin-selective addition in accord with our previous observations. ${ }^{2}$ (Compounds 7a', 7a”, 43-50, 54-69) 


\section{General procedure for the Swern oxidation:}

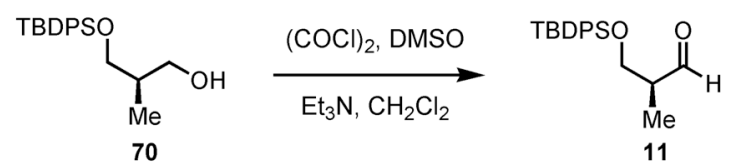

Methyl sulfoxide $(177 \mu \mathrm{L}, 2.47 \mathrm{mmol})$ in $\mathrm{CH}_{2} \mathrm{Cl}_{2}(1.6 \mathrm{~mL})$ was added via cannula to a cooled solution of $(\mathrm{COCl})_{2}(106 \mu \mathrm{L}, 1.23 \mathrm{mmol})$ in $\mathrm{CH}_{2} \mathrm{Cl}_{2}(2.6 \mathrm{~mL})$ at $-78{ }^{\circ} \mathrm{C}$. After stirring for $15 \mathrm{~min}$, alcohol $70(270 \mathrm{mg}, 0.82 \mathrm{mmol})$ in $\mathrm{CH}_{2} \mathrm{Cl}_{2}(1.6 \mathrm{~mL})$ was added slowly via cannula. The resulting cloudy solution was stirred for $1 \mathrm{~h}$ before adding $\mathrm{Et}_{3} \mathrm{~N}$ $(0.52 \mathrm{~mL}, 3.70 \mathrm{mmol})$ neat. The reaction was then warmed to $0{ }^{\circ} \mathrm{C}$ and stirred for $15 \mathrm{~min}$ after which $1.5 \mathrm{~mL}$ of water was added. The reaction mixture was then poured into a separatory funnel containing $15 \mathrm{ml}$ of EtOAc and the organic layer was washed with water $(2 \times 10 \mathrm{~mL})$, sat. $\mathrm{NH}_{4} \mathrm{Cl}(3 \times 10 \mathrm{~mL})$, sat. $\mathrm{NaHCO}_{3}(1 \times 10 \mathrm{~mL})$ and brine successively. Crude aldehyde 11 was obtained after drying over anhydrous $\mathrm{MgSO}_{4}$ followed by solvent removal. The aldehyde was further dried by azeotropic removal of water (concentration $3 \times$ from anhydrous benzene).

\section{Assembly of the seco-acid precursor of $(9 S)$-dihydroerythronolide A $\left(1^{\text {st }}\right.$ generation approach).}

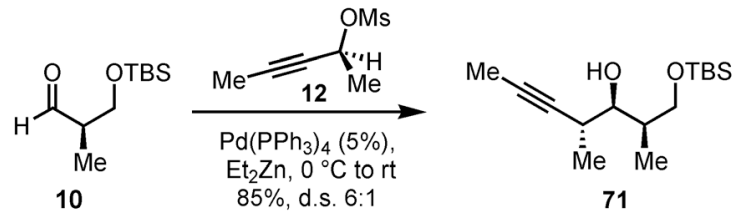

$(2 R, 3 R, 4 R)-1-(t e r t-b u t y l d i m e t h y l s i l a n y l o x y)-2,4-d i m e t h y l-5-h e p t y n-3-o l, ~ 15:^{1}$ A solution of mesylate $12(7.15 \mathrm{~g}, 44.1 \mathrm{mmol})$ in THF $(10 \mathrm{~mL})$ and a solution of aldehyde 10 (5.00 g, $24.5 \mathrm{mmol})$ in THF (10 mL) were added successively via cannula to 
a stirring solution of $\mathrm{Pd}\left(\mathrm{PPh}_{3}\right)_{4}(1.41 \mathrm{~g}, 1.22 \mathrm{mmol})$ in $\mathrm{THF}(117 \mathrm{~mL})$ at room temperature. The flask was cooled to $0{ }^{\circ} \mathrm{C}$ before adding a freshly prepared solution of $\mathrm{Et}_{2} \mathrm{Zn}(58.3 \mathrm{mmol}, 58.3 \mathrm{~mL}, 1.0 \mathrm{M}$ in hexanes) dropwise over $1 \mathrm{~h}$ via cannula. The reaction was slowly warmed to room temperature and stirred for $8 \mathrm{~h}$. The flask was then cooled to $0{ }^{\circ} \mathrm{C}$ and $50 \mathrm{~mL}$ of a saturated solution of $\mathrm{NH}_{4} \mathrm{Cl}$ was added. The aqueous layer was extracted with EtOAc $(3 \times 70 \mathrm{~mL})$ and the combined organic layer was washed with sat $\mathrm{NaHCO}_{3}$, brine and dried over anhydrous $\mathrm{MgSO}_{4}$. The crude material was purified by flash column chromatography on silica gel eluting successively with $2 \%, 4 \%$ and $6 \%$ EtOAc/ hexanes to provide $5.63 \mathrm{~g}(85 \%)$ of 71 as $6: 1$ mixture of diastereomers as determined after analysis of the crude. Alcohol 71 was immediately used in the next step.

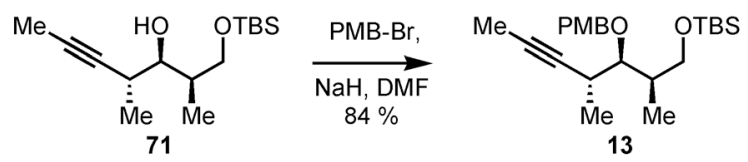

\section{(2R,3R,4R)-1-(tert-butyldimethylsilanyloxy)-3-( $p$-methoxybenzyloxy)-2,4-}

dimethyl-5-heptyn, 13. Sodium hydride $(310 \mathrm{mg}, 7.75 \mathrm{mmol})$ was added at once to a stirring solution of homopropargyl alcohol 71 (d.r. $=6: 1 ; 1.91 \mathrm{~g}, 7.05 \mathrm{mmol})$ and PMB$\mathrm{Br}(1.84$ g. $9.16 \mathrm{mmol})$ in $\mathrm{DMF}(47 \mathrm{~mL})$ at $-20{ }^{\circ} \mathrm{C}$. The reaction was allowed to reach room temperature and stirred for $48 \mathrm{~h}$ before pouring into a separatory funnel containing EtOAc $(100 \mathrm{~mL})$ and water $(80 \mathrm{~mL})$. The phases were separated and the organic layer further washed with water $(3 \times 80 \mathrm{~mL})$, sat. $\mathrm{NaHCO}_{3}$, brine and dried over anhydrous $\mathrm{Na}_{2} \mathrm{SO}_{4}$. The residue obtained after solvent removal was purified by flash column chromatography on silica gel eluting successively with $1 \%, 2 \%$ and $3 \%$ EtOAc/ hexanes to afford $1.89 \mathrm{~g}(84 \%)$ of pure 13. $[\alpha]_{589}{ }^{20}-16.3^{\circ}\left(c 0.93, \mathrm{CHCl}_{3}\right) ;{ }^{1} \mathrm{H} \mathrm{NMR}$ $\left(400 \mathrm{MHz}, \mathrm{CDCl}_{3}\right) \delta$ 7.32-7.30 (m, 2H), 6.89-6.86 (m, 2H), $4.74(\mathrm{~A}$ of $\mathrm{AB}, J=13.5 \mathrm{~Hz}$, 
1H), $4.53(\mathrm{~B}$ of AB, $J=13.5 \mathrm{~Hz}, 1 \mathrm{H}), 3.81(\mathrm{~s}, 3 \mathrm{H}), 3.57(\mathrm{dd}, J=12.3,6.1 \mathrm{~Hz}, 1 \mathrm{H}), 3.48$ (dd, $J=12.3,7.6 \mathrm{~Hz}, 1 \mathrm{H}), 3.44(\mathrm{dd}, J=8.8,5.1 \mathrm{~Hz}, 1 \mathrm{H}), 2.75-2.69(\mathrm{~m}, 1 \mathrm{H}), 1.98-1.89$ (m, 1H), $1.81(\mathrm{~d}, J=3.0 \mathrm{~Hz}, 3 \mathrm{H}), 1.14(\mathrm{~d}, J=8.8 \mathrm{~Hz}, 3 \mathrm{H}), 0.91(\mathrm{~s}, 9 \mathrm{H}), 0.89$ (d, $J=8.7$ $\mathrm{Hz}, 1 \mathrm{H}), 0.05$ (s, 6H); ${ }^{13} \mathrm{C}$ NMR $\left(100 \mathrm{MHz}, \mathrm{CDCl}_{3}\right) \delta$ 159.2, 131.6, 129.9, 129.7, 113.8, $82.4,82.2,74.4,65.8,55.5,38.4,29.7,26.1,18.4,11.4,3.9,-5.1,-5.2$; IR (thin film, $\mathrm{NaCl}) 2955,2929,2858,1514,1249,1093,1039,836,775 \mathrm{~cm}^{-1}$; LRMS (EI, Na) calcd for $\mathrm{C}_{23} \mathrm{H}_{38} \mathrm{O}_{3} \mathrm{Si}, 413.63 \mathrm{~m} / \mathrm{z}(\mathrm{M}+\mathrm{Na})$; observed, $413.42(\mathrm{M}+\mathrm{Na})^{+} \mathrm{m} / z$

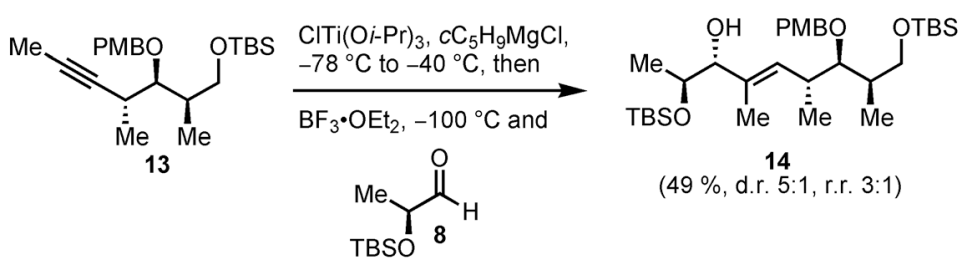

\section{$(E)-(2 R, 3 R, 4 R, 7 R, 8 S)-1,8-d i(t e r t-b u t y l d i m e t h y l s i l a n y l o x y)-3-(p-$}

methoxybenzyloxy)-2,4,6-trimethylnon-5-ene-7-ol, 14 . To a $-78{ }^{\circ} \mathrm{C}$ solution of alkyne $13(500 \mathrm{mg}, 1.29 \mathrm{mmol}$; d.r. $=6: 1)$ in $13 \mathrm{~mL}$ of toluene, was added sequentially ClTi(Oi$\operatorname{Pr}_{3}(1.0 \mathrm{M}$ in hexanes; $2.84 \mathrm{~mL}, 2.84 \mathrm{mmol})$ and $c-\mathrm{C}_{5} \mathrm{H}_{9} \mathrm{MgCl}(2.0 \mathrm{M}$ in diethyl ether; $2.84 \mathrm{~mL}, 5.68 \mathrm{mmol}$ ) in a dropwise manner via a dry gas-tight syringe. The resulting yellow solution was slowly warmed to $-40{ }^{\circ} \mathrm{C}$ and stirred for $1 \mathrm{~h}$ during which the reaction turned dark brown. The flask was then cooled to $-78{ }^{\circ} \mathrm{C}$ and $\mathrm{BF}_{3} \cdot \mathrm{OEt}_{2}(360 \mu \mathrm{L}$, $2.84 \mathrm{mmol}$ ) was added in a dropwise manner. Following a stirring period of $10 \mathrm{~min}$ at $-78{ }^{\circ} \mathrm{C}$, the flask was further cooled to $-100{ }^{\circ} \mathrm{C}$ by immersing into a liquid $\mathrm{N}_{2} /$ pentane bath. Aldehyde 8 ( $778 \mathrm{mg}, 4.13 \mathrm{mmol})$ was then added as a solution in toluene $(0.5 \mathrm{~mL})$ down the side of the flask via a gas tight syringe. The transfer was completed with additional toluene $(2 \times 0.5 \mathrm{~mL})$. Stirring was maintained for $1 \mathrm{~h}$ at $-100{ }^{\circ} \mathrm{C}$, before warming to $-78{ }^{\circ} \mathrm{C}$. Saturated $\mathrm{NH}_{4} \mathrm{Cl}$ solution $(10 \mathrm{~mL})$ was then added and the 
suspension was allowed to reach ambient temperature before partitioning between EtOAc $(20 \mathrm{~mL})$ and water $(10 \mathrm{~mL})$. The phases were separated and the aqueous layer was extracted with EtOAc $(3 \times 20 \mathrm{~mL})$. The combined organic layer was then washed with sat. $\mathrm{NaHCO}_{3}$ solution $(2 \times 40 \mathrm{~mL})$, brine $(1 \times 40 \mathrm{~mL})$ and dried over anhydrous $\mathrm{Na}_{2} \mathrm{SO}_{4}$. The crude material was purified by flash column chromatography on silica gel eluting successively with $2 \%, 4 \%, 6 \%, 10 \%$ and $15 \%$ EtOAc -hexanes to provide $370 \mathrm{mg}$ (49 $\%)$ of a diastereomeric mixture of $\mathbf{1 4}$ (d.r. $=5: 1$ at C7). $[\alpha]_{589}{ }^{20}-5.1^{\circ}\left(c 0.65, \mathrm{CHCl}_{3}\right) ;{ }^{1} \mathrm{H}$ NMR (500 MHz, $\left.\mathrm{CDCl}_{3}\right) \delta$ 7.26-7.24 (m, 2H), 6.87-6.85 (m, 2H), 5.57 (d, $J=9.6 \mathrm{~Hz}$, $1 \mathrm{H}), 4.55(\mathrm{~A}$ of AB, $J=10.8 \mathrm{~Hz}, 1 \mathrm{H}), 4.46(\mathrm{~B}$ of AB, $J=10.8 \mathrm{~Hz}, 1 \mathrm{H}), 3.96(\mathrm{~d}, J=3.5$ Hz, 1H), 3.96-3.93 (m, 1H), 3.80 (s, 3H), 3.52 (dd, $J=9.7,7.0 \mathrm{~Hz}, 1 \mathrm{H}), 3.44$ (dd, $J=9.7$, $6.1 \mathrm{~Hz}, 1 \mathrm{H}), 3.39$ (dd, $J=6.7,4.0 \mathrm{~Hz}, 1 \mathrm{H}), 2.80-2.68(\mathrm{~m}, 1 \mathrm{H}), 1.87-1.81(\mathrm{~m}, 1 \mathrm{H}), 1.61$ (s, 3H), $0.98(\mathrm{~d}, J=9.1 \mathrm{~Hz}, 3 \mathrm{H}), 0.96(\mathrm{~d}, J=6.9 \mathrm{~Hz}, 3 \mathrm{H}), 0.93-0.91(\mathrm{~m}, 21 \mathrm{H}), 0.097$ (s, 3H), 0.088 (s, 3H), 0.045 (s, 3H), 0.038 (s, 3H); ${ }^{13} \mathrm{C} \mathrm{NMR}\left(126 \mathrm{MHz}, \mathrm{CDCl}_{3}\right.$ ) $\delta$ 159.1, $132.6,132.1,130.0,129.3,113.8,83.4,79.2,74.5,70.8,66.0,55.5,38.8,35.6,26.2,26.0$, 18.5, 18.3, 18.1, 17.1, 14.1, 11.6, -4.3,-4.7, -5.13, -5.15; IR (thin film, $\mathrm{NaCl}$ ) 2955, 2929, 2856, 1514, 1471, 1463, 1249, 1087, 1039, 836, 775, $668 \mathrm{~cm}^{-1}$; LRMS (EI, Na) calcd for $\mathrm{C}_{32} \mathrm{H}_{60} \mathrm{O}_{5} \mathrm{Si}_{2}, 603.99 \mathrm{~m} / z(\mathrm{M}+\mathrm{Na})$; observed, $603.46(\mathrm{M}+\mathrm{Na})^{+} \mathrm{m} / z$.

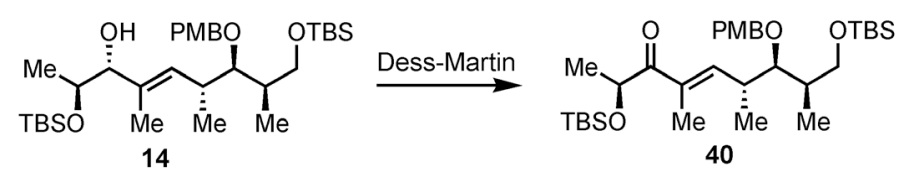

\section{(E)-(2R,3R,4R,8S)-1,8-di(tert-butyldimethylsilanyloxy)-3-(p-methoxybenzyloxy)-}

2,4,6-trimethylnon-5-ene-7-one, 40. To a stirring solution of 14 (370 $\mathrm{mg}, 0.637 \mathrm{mmol})$ in dichloromethane (12 mL, reagent grade from a bottle) was added 1,1,1-triacetoxy-1,1dihydro-1,2-benziodoxol-3-(1H)-one (540 mg, $1.28 \mathrm{mmol})$ at room temperature. After 1 
$\mathrm{h}$ of stirring, the reaction was diluted with a solution of $20 \%$ EtOAc/ hexanes $(10 \mathrm{~mL})$ and most of the solvent was removed. The residue was dissolved in $30 \mathrm{~mL}$ of EtOAc/ hexanes and washed with a $1: 1$ mixture of $10 \% \mathrm{Na}_{2} \mathrm{~S}_{2} \mathrm{O}_{3}$ and sat $\mathrm{NaHCO}_{3}$ until a clear organic layer was obtained. The organic layer was then washed with brine and dried over anhydrous $\mathrm{Na}_{2} \mathrm{SO}_{4}$. The solvent was concentrated and the residue was purified by flash column chromatography eluting with $10 \% \mathrm{EtOAc} /$ hexanes to afford $335 \mathrm{mg}$ of enone $\mathbf{4 0}$ (91\%). Enone 40 was immediately used in the following step.

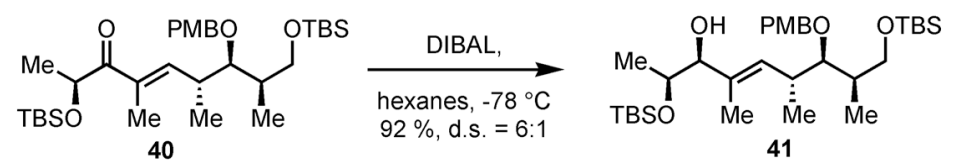

\section{(E)-(2R,3R,4R,7S,8S)-1,8-di(tert-butyldimethylsilanyloxy)-3-( $p$ -}

methoxybenzyloxy)-2,4,6-trimethylnon-5-ene-7-ol, 41. To a cooled solution of enone 40 (573 $\mathrm{mg}, 0.990 \mathrm{mmol})$ in hexanes at $-78{ }^{\circ} \mathrm{C}$ was added DIBAL (1.0 $\mathrm{M}$ in hexanes; $1.48 \mathrm{~mL}, 1.48 \mathrm{mmol}$ ) slowly via syringe down the side of the flask. After stirring for 10 min, $2.0 \mathrm{~mL}$ of $\mathrm{MeOH}$ was added followed by $5 \mathrm{~mL}$ of saturated Rochelle salt solution. The suspension was allowed to reach room temperature before diluting with EtOAc (10 $\mathrm{mL})$ and water $(10 \mathrm{~mL})$. The phases were separated and the aqueous layer was further extracted with EtOAc $(3 \times 10 \mathrm{~mL})$. The combined organic layer was then washed with $\mathrm{NaHCO}_{3}(2 \times 20 \mathrm{~mL})$ and brine. After drying over anhydrous $\mathrm{Na}_{2} \mathrm{SO}_{4}$, the solvent was removed and the residue was purified by flash column chromatography eluting with $8 \%$ EtOAc/ hexanes affording $528 \mathrm{mg}$ of unsaturated alcohol $41\left(92 \%\right.$, d.s. $=6: 1$ from ${ }^{1} \mathrm{H}$ NMR of crude product). $[\alpha]_{589}{ }^{20}+12.8^{\circ}\left(c 0.67, \mathrm{CHCl}_{3}\right) ;{ }^{1} \mathrm{H} \mathrm{NMR}\left(500 \mathrm{MHz}, \mathrm{CDCl}_{3}\right) \delta$ 7.29-7.27 (m, 2H), 6.87-6.86 (m, 2H), $5.48(\mathrm{~d}, J=9.8 \mathrm{~Hz}, 1 \mathrm{H}), 4.56(\mathrm{~A}$ of AB, $J=10.6$ $\mathrm{Hz}, 1 \mathrm{H}), 4.45(\mathrm{~B}$ of AB, $J=10.6 \mathrm{~Hz}, 1 \mathrm{H}), 3.80(\mathrm{~s}, 3 \mathrm{H}), 3.77-3.68(\mathrm{~m}, 2 \mathrm{H}), 3.53$ (dd, $J=$ 
9.8, $6.7 \mathrm{~Hz}, 1 \mathrm{H}), 3.46(\mathrm{dd}, J=9.8,6.0 \mathrm{~Hz}, 1 \mathrm{H}), 3.38(\mathrm{dd}, J=6.2,4.4 \mathrm{~Hz}, 1 \mathrm{H}), 2.76-2.69$ (m, 1H), 1.87-1.78 (m, 1H), $1.64(\mathrm{~d}, J=1.1 \mathrm{~Hz}, 3 \mathrm{H}), 1.05(\mathrm{~d}, J=5.9 \mathrm{~Hz}, 3 \mathrm{H}), 0.94-0.91$ (m, 24H), $0.12(\mathrm{~s}, 3 \mathrm{H}), 0.11(\mathrm{~s}, 3 \mathrm{H}), 0.051(\mathrm{~s}, 3 \mathrm{H}), 0.049$ (s, 3H); ${ }^{13} \mathrm{C}$ NMR (126 MHz, $\left.\mathrm{CDCl}_{3}\right) \delta 159.2,133.5,133.2,131.9,129.6,113.8,83.3,74.6,71.3,66.0,55.5,38.9,35.7$, $26.2,26.1,20.3,18.5,18.3,18.1,12.1,11.8,-3.8,-4.5,-5.13,-5.15$; IR (thin film, $\mathrm{NaCl}) 2956,2929,2856,1249,1132,1087,1040,1005,835,776,671 \mathrm{~cm}^{-1}$; LRMS (EI, Na) calcd for $\mathrm{C}_{32} \mathrm{H}_{60} \mathrm{O}_{5} \mathrm{Si}_{2}, 603.99 \mathrm{~m} / z(\mathrm{M}+\mathrm{Na})$; observed, $603.43(\mathrm{M}+\mathrm{Na})^{+} \mathrm{m} / z$.

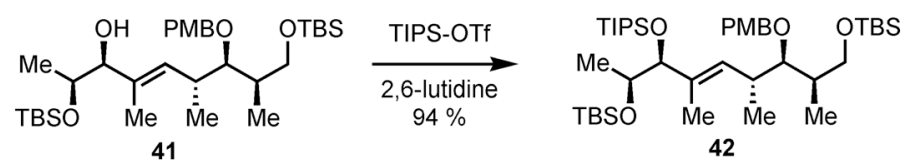

(E)-(2R,3R,4R,7S,8S)-1,8-di(tert-butyldimethylsilanyloxy)-3-( $p$ -

methoxybenzyloxy)-7-(tri-isopropylsilanyloxy)-2,4,6-trimethylnon-5-ene, 42. To a cooled solution of allylic alcohol $41(198 \mathrm{mg}, 0.339 \mathrm{mmol})$ and 2,6-lutidine $(0.12 \mathrm{~mL}, 1.0$ mmol) in dichloromethane $(3.4 \mathrm{~mL})$ at $0{ }^{\circ} \mathrm{C}$, was added TIPS-OTf $(0.14 \mathrm{~mL}, 0.51 \mathrm{mmol})$ dropwise. The reaction was held at $0{ }^{\circ} \mathrm{C}$ for $1 \mathrm{~h}$ before diluting with $20 \% \mathrm{EtOAc} /$ hexanes $(10 \mathrm{~mL})$. The organic layer was then washed with saturated $\mathrm{NaHCO}_{3}(2 \times 10$ $\mathrm{mL}$ ), brine and dried over anhydrous $\mathrm{Na}_{2} \mathrm{SO}_{4}$. The solvent was concentrated and the residue was purified by flash column chromatography eluting with $2 \%$ EtOAc/ hexanes affording $237 \mathrm{mg}$ of $\mathbf{4 2}(94 \%)$. $[\alpha]_{589}{ }^{20}-24.0^{\circ}\left(c 0.84, \mathrm{CHCl}_{3}\right) ;{ }^{1} \mathrm{H} \mathrm{NMR}(500 \mathrm{MHz}$, $\left.\mathrm{CDCl}_{3}\right) 7.27-7.26(\mathrm{~m}, 2 \mathrm{H}), 6.86-6.85(\mathrm{~m}, 2 \mathrm{H}), 5.62(\mathrm{~d}, J=9.6 \mathrm{~Hz}, 1 \mathrm{H}), 4.60(\mathrm{~A}$ of $\mathrm{AB}, J$ $=10.9 \mathrm{~Hz}, 1 \mathrm{H}), 4.48(\mathrm{~B}$ of AB, $J=10.9 \mathrm{~Hz}, 1 \mathrm{H}), 4.12(\mathrm{~d}, J=4.4 \mathrm{~Hz}, 1 \mathrm{H}), 3.91-3.86(\mathrm{~m}$, 1H), $3.81(\mathrm{~s}, 3 \mathrm{H}), 3.48(\mathrm{dd}, J=9.7,5.6 \mathrm{~Hz}, 1 \mathrm{H}), 3.44(\mathrm{dd}, J=9.7,5.9 \mathrm{~Hz}, 1 \mathrm{H}), 3.36(\mathrm{dd}$, $J=5.2,5.2 \mathrm{~Hz}, 1 \mathrm{H}), 2.80-2.71(\mathrm{~m}, 1 \mathrm{H}), 1.85-1.76(\mathrm{~m}, 1 \mathrm{H}), 1.68(\mathrm{~d}, J=0.8 \mathrm{~Hz}, 3 \mathrm{H})$, 1.052-1.046 (m, 21H), 0.99-.096 (m, 9H), $0.91(\mathrm{~s}, 9 \mathrm{H}), 0.88(\mathrm{~s}, 9 \mathrm{H}), 0.05(\mathrm{~s}, 3 \mathrm{H})$, 
0.039(s, 3H), $0.038(\mathrm{~s}, 3 \mathrm{H}), 0.031$ (s, 3H); ${ }^{13} \mathrm{C}$ NMR $\left(126 \mathrm{MHz}, \mathrm{CDCl}_{3}\right) \delta$ 159.0, 133.9, $132.1,129.6,129.0,113.7,84.1,79.7,74.3,72.9,66.0,55.5,18.5,18.37,18.36,18.3$, $18.2,18.1,15.4,12.9,1.7,-4.35,-4.40,-5.2$; IR (thin film, NaCl) 2956, 2929, 2856, $1513,1463,1249,1105,835,774,680 \mathrm{~cm}^{-1}$; LRMS (EI, Na) calcd for $\mathrm{C}_{41} \mathrm{H}_{80} \mathrm{O}_{5} \mathrm{Si}_{3}$, $760.33 \mathrm{~m} / z(\mathrm{M}+\mathrm{Na})$; observed, $760.77(\mathrm{M}+\mathrm{Na})^{+} \mathrm{m} / \mathrm{z}$.

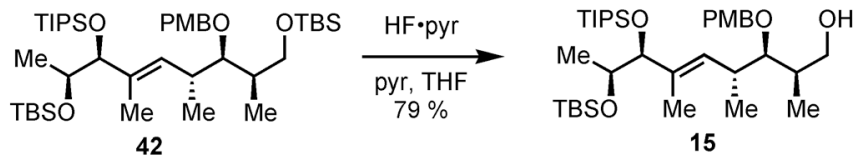

\section{(E)-(2R,3R,4R,7S,8S)-8-di(tert-butyldimethylsilanyloxy)-3-( $p$ -}

methoxybenzyloxy)-7-(tri-isopropylsilanyloxy)-2,4,6-trimethylnon-5-ene-1-ol, 15. To a solution of $42(237 \mathrm{~g}, 0.321 \mathrm{mmol})$ in $5 \mathrm{~mL}$ of THF was added successively $0.72 \mathrm{~mL}$ of pyridine and $0.97 \mathrm{~mL}$ of $\mathrm{HF} \bullet$ pyr complex. After stirring at room temperature for $2 \mathrm{~h}$, the reaction flask was immersed in an ice-bath and saturated $\mathrm{NaHCO}_{3}(10 \mathrm{~mL})$ was added carefully. The phases were separated and the aqueous layer was extracted with EtOAc (3 $\times 20 \mathrm{~mL}$ ). The combined organic layer was washed with brine and dried over anhydrous $\mathrm{Na}_{2} \mathrm{SO}_{4}$. The solvent was concentrated and the residue was purified by flash column chromatography eluting successively with $2 \%$ and $30 \%$ EtOAc/ hexanes to afford 159 mg of $15(79 \%)$. $[\alpha]_{589}{ }^{20}-29.7^{\circ}\left(c \quad 0.56, \mathrm{CHCl}_{3}\right) ;{ }^{1} \mathrm{H} \mathrm{NMR}\left(500 \mathrm{MHz}, \mathrm{CDCl}_{3}\right)$ 7.28-7.26 $(\mathrm{m}, 2 \mathrm{H}), 6.88-6.85(\mathrm{~m}, 2 \mathrm{H}), 5.63(\mathrm{~d}, J=9.8 \mathrm{~Hz}, 1 \mathrm{H}), 4.63(\mathrm{~A}$ of $\mathrm{AB}, J=11.1 \mathrm{~Hz}, 1 \mathrm{H})$, 4.49 (B of $\mathrm{AB}, J=11.1 \mathrm{~Hz}, 1 \mathrm{H}), 4.14(\mathrm{~d}, J=4.3 \mathrm{~Hz}, 1 \mathrm{H}), 3.92-3.88(\mathrm{~m}, 1 \mathrm{H}), 3.81(\mathrm{~s}$, $3 \mathrm{H}), 3.59(\mathrm{dd}, J=10.7,6.4 \mathrm{~Hz}, 1 \mathrm{H}), 3.50(\mathrm{dd}, J=10.7,5.0 \mathrm{~Hz}, 1 \mathrm{H}), 3.41(\mathrm{dd}, J=4.9$, $4.9 \mathrm{~Hz}, 1 \mathrm{H}), 2.88-2.77(\mathrm{~m}, 1 \mathrm{H}), 1.98-1.90(\mathrm{~m}, 1 \mathrm{H}), 1.70(\mathrm{~d}, J=1.0 \mathrm{~Hz}, 3 \mathrm{H}), 1.05-0.99$ $(\mathrm{m}, 30 \mathrm{H}), 0.88(\mathrm{~s}, 9 \mathrm{H}), 0.054(\mathrm{~s}, 3 \mathrm{H}), 0.048(\mathrm{~s}, 3 \mathrm{H}) ;{ }^{13} \mathrm{C} \mathrm{NMR}\left(126 \mathrm{MHz}, \mathrm{CDCl}_{3}\right)$ $\delta 159.2,134.3,131.4,129.4,129.2,128.6,113.9,84.8,79.6,73.6,72.9,66.7,55.5,38.2$, 
$35.1,26.1,18.44,18.36,18.2,18.0,15.5,12.6,12.5,-4.3,-4.4$; IR (thin film, $\mathrm{NaCl}$ ) $3419,2958,2867,1514,1463,1389,1249,1101,1039,883,835,735,678 \mathrm{~cm}^{-1}$; LRMS (EI, Na) calcd for $\mathrm{C}_{35} \mathrm{H}_{66} \mathrm{O}_{5} \mathrm{Si}_{2}, 645.07 \mathrm{~m} / z(\mathrm{M}+\mathrm{Na})$; observed, $645.75(\mathrm{M}+\mathrm{Na})^{+} \mathrm{m} / z$.

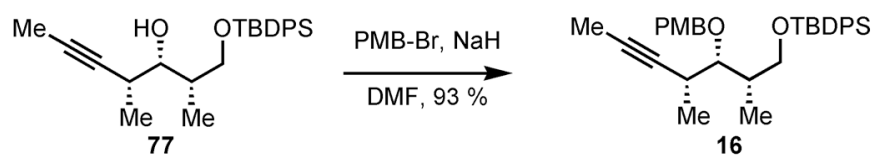

(2S,3S,4R)-1-(tert-butyldiphenylsilanyloxy)-3-( $p$-methoxybenzyloxy)-2,4-

dimethyl-5-heptyn, 16. Sodium hydride $(137 \mathrm{mg}, 3.43 \mathrm{mmol})$ was added at once to a stirring solution of homopropargyl alcohol $7^{2}$ (1.23 g, $\left.3.12 \mathrm{mmol}\right)$ and PMB-Br (755 $\mathrm{mg}, 3.74 \mathrm{mmol})$ in DMF $(16 \mathrm{~mL})$ at $-20{ }^{\circ} \mathrm{C}$. The reaction was allowed to reach room temperature and stirred overnight before pouring into a separatory funnel containing EtOAc $(30 \mathrm{~mL})$ and water $(20 \mathrm{~mL})$. The phases were separated and the organic layer further washed with water $(3 \times 20 \mathrm{~mL})$, sat. $\mathrm{NaHCO}_{3}$, brine and dried over anhydrous $\mathrm{Na}_{2} \mathrm{SO}_{4}$. The residue obtained after solvent removal was purified by flash column chromatography on silica gel eluting successively with $1 \%, 2 \%$ and $3 \% \mathrm{EtOAc} /$ hexanes to afford $1.49 \mathrm{~g}(93 \%)$ of pure 16. $[\alpha]_{589}{ }^{20}-1.32^{\circ}\left(c 0.38, \mathrm{CHCl}_{3}\right) ;{ }^{1} \mathrm{H}$ NMR (500 MHz, $\left.\mathrm{CDCl}_{3}\right) \delta$ 7.71-7.68 (m, 4H), 7.46-7.37 (m, 6H), 7.23-7.21 (m, 2H), 6.86-6.84 (m, 2H), $4.60(\mathrm{~A}$ of AB, $J=11.1 \mathrm{~Hz}, 1 \mathrm{H}), 4.55(\mathrm{~B}$ of AB, $J=11.1 \mathrm{~Hz}, 1 \mathrm{H}), 3.81(\mathrm{~s}, 3 \mathrm{H})$, 3.67-3.34 (m, 2H), $3.55(\mathrm{dd}, J=9.8,5.7 \mathrm{~Hz}, 1 \mathrm{H}), 2.68-2.61(\mathrm{~m}, 1 \mathrm{H}), 2.37-2.29(\mathrm{~m}, 1 \mathrm{H})$, $1.83(\mathrm{~d}, J=2.4 \mathrm{~Hz}, 3 \mathrm{H}), 1.27(\mathrm{~d}, J=2.9 \mathrm{~Hz}, 3 \mathrm{H}), 1.10(\mathrm{~s}, 9 \mathrm{H}), 0.85(\mathrm{~d}, J=6.9 \mathrm{~Hz}, 3 \mathrm{H})$; ${ }^{13} \mathrm{C}$ NMR $\left(126 \mathrm{MHz}, \mathrm{CDCl}_{3}\right) \delta 159.3,135.9,135.8,134.2,134.1,131.4,129.8,129.5$, $127.9,127.8,113.9,82.5,81.9,74.9,66.8,55.5,38.8,29.9,27.1,19.5,18.6,14.4,10.6$, 3.8; IR (thin film, $\mathrm{NaCl}$ ) 2965, 2933, 2958, 1514, 1465, 1428, 1248, 112, 1079, 1039, 
824, $702 \mathrm{~cm}^{-1}$; LRMS (EI, Na) calcd for $\mathrm{C}_{33} \mathrm{H}_{42} \mathrm{O}_{3} \mathrm{Si}, 537.77 \mathrm{~m} / z(\mathrm{M}+\mathrm{Na})$; observed, $537.55(\mathrm{M}+\mathrm{Na})^{+} \mathrm{m} / z$

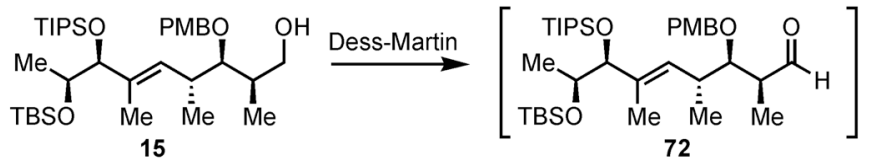

\section{$(E)-(2 R, 3 R, 4 R, 8 S)-1,8-d i(t e r t-b u t y l d i m e t h y l s i l a n y l o x y)-3-(p-$}

methoxybenzyloxy)-2,4,6-trimethylnon-5-ene-1-al, 72. To a stirring solution of 15 (20 $\mathrm{mg}, 0.032 \mathrm{mmol})$ in dichloromethane $(0.64 \mathrm{~mL}$, reagent grade from a bottle $)$ at $0{ }^{\circ} \mathrm{C}$ was added 1,1,1-triacetoxy-1,1-dihydro-1,2-benziodoxol-3-(1H)-one (27 mg, $0.064 \mathrm{mmol})$ at once. The reaction was stirred at $0{ }^{\circ} \mathrm{C}$ for $1 \mathrm{~h}$ and at room temperature for $30 \mathrm{~min}$ before diluting with a solution of $20 \%$ EtOAc/ hexanes $(2 \mathrm{~mL})$. Most of the solvent was removed. The residue was dissolved in $5 \mathrm{~mL}$ of EtOAc/ hexanes and washed with a 1:1 mixture of $10 \% \mathrm{Na}_{2} \mathrm{~S}_{2} \mathrm{O}_{3}$ and sat $\mathrm{NaHCO}_{3}$ until a clear organic layer was obtained. The organic layer was then washed with brine and dried over anhydrous $\mathrm{MgSO}_{4}$. Crude aldehyde 72, obtained after solvent removal, was further dried by azeotropic removal of water (concentration $3 \times$ from anhydrous benzene). The aldehyde was used in the subsequent experiment without further purification.

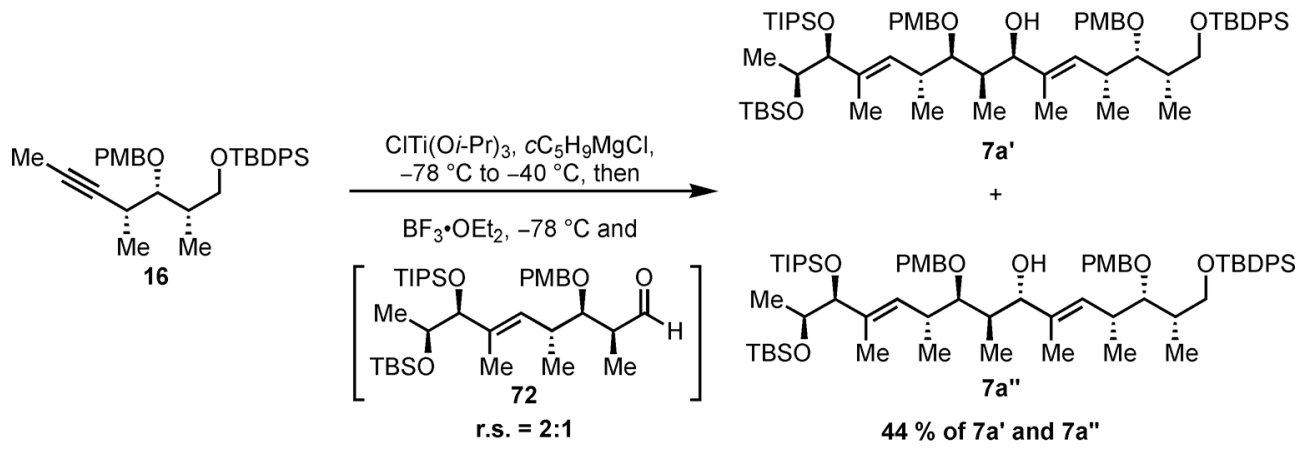

Synthesis of diene $7 \mathbf{a}^{\prime}$ and $7 \mathbf{a}^{\text {" }}$ via titanium reductive coupling. To a $-78{ }^{\circ} \mathrm{C}$ solution of alkyne $16(50 \mathrm{mg}, 0.097 \mathrm{mmol})$ in $0.97 \mathrm{~mL}$ of toluene, was added sequentially 
$\mathrm{ClTi}(\mathrm{O} i-\mathrm{Pr})_{3}(1.0 \mathrm{M}$ in hexanes; $150 \mu \mathrm{L}, 0.150 \mathrm{mmol})$ and $c-\mathrm{C}_{5} \mathrm{H}_{9} \mathrm{MgCl}(2.0 \mathrm{M}$ in diethyl ether; $150 \mu \mathrm{L}, 0.300 \mathrm{mmol}$ ) in a dropwise manner via a dry gas-tight syringe. The resulting yellow solution was slowly warmed to $-40{ }^{\circ} \mathrm{C}$ and stirred for $2 \mathrm{~h}$ during which the reaction turned dark brown. The flask was then cooled to $-78{ }^{\circ} \mathrm{C}$ and $\mathrm{BF}_{3} \bullet \mathrm{OEt}_{2}(18$ $\mu \mathrm{L}, 0.15 \mathrm{mmol}$ ) was added in a dropwise manner. Following a stirring period of $10 \mathrm{~min}$ at $-78^{\circ} \mathrm{C}$, aldehyde $72(20 \mathrm{mg}, 0.032 \mathrm{mmol})$ was then added as a solution in toluene $(0.1$ $\mathrm{mL}$ ) down the side of the flask via a gas tight syringe. The transfer was quantitated with additional toluene $(2 \times 0.1 \mathrm{~mL})$. Stirring was maintained for $1 \mathrm{~h}$ at $-78{ }^{\circ} \mathrm{C}$, before the addition of saturated $\mathrm{NH}_{4} \mathrm{Cl}$ solution $(0.3 \mathrm{~mL})$. The suspension was allowed to reach ambient temperature before partitioning between EtOAc $(5 \mathrm{~mL})$ and water $(3 \mathrm{~mL})$. The phases were separated and the aqueous layer was extracted with EtOAc $(3 \times 5 \mathrm{~mL})$. The combined organic layer was then washed with sat. $\mathrm{NaHCO}_{3}$ solution $(2 \times 10 \mathrm{~mL})$, brine $(1 \times 10 \mathrm{~mL})$ and dried over anhydrous $\mathrm{Na}_{2} \mathrm{SO}_{4}$. The crude material was purified by flash column chomatography eluting successively with $2 \%, 3 \%, 5 \%, 7 \%, 10 \%$ and $15 \%$ EtOAc/ hexanes to provide $16 \mathrm{mg}(44 \%)$ of $\mathbf{7 a}$ ' and $\mathbf{7 a}$ " as the major regioisomer. Compound 7a' was obtained as an inseparable mixture with some of the minor regioisomer. The amount of this minor contaminant was determined from analysis of the ${ }^{1} \mathrm{H}$ spectrum and was not included in the yield reported.

Regioselectivity data for $7 \mathbf{a}$ ' and $7 \mathbf{a}$ ". The residue obtained after a titanium reductive coupling as described above was filtered through a short pad of silica eluting successively with $2 \%(50 \mathrm{~mL})$ and $4 \%(50 \mathrm{~mL})$ EtOAc/ hexanes until all traces of reduced alkyne 16 were removed. All remaining organics were removed by washing the 
silica with $200 \mathrm{~mL}$ of $100 \%$ EtOAc. Analysis of the partially purified mixture by ${ }^{1} \mathrm{H}$ NMR shows an approximately 2:1 mixture of regioisomers.

Data for major diastereomer $(E, E)-(2 S, 3 S, 4 R, 7 R, 8 R, 9 R, 10 R, 13 S, 14 S)-1-(t e r t-$ butyldiphenylsilanyloxy)-3,9-di( $p$-methoxybenzyloxy)-13-(tri-isopropylsilanyloxy)14-(tert-butyldimethylsilanyloxy)-2,4,6,8,10,12-hexamethylpentadec-5,11-diene-7-ol, 7a'. $[\alpha]_{589}{ }^{20}-13.4^{\circ}\left(c\right.$ 0.7, $\left.\mathrm{CHCl}_{3}\right) ;{ }^{1} \mathrm{H}$ NMR $\left(500 \mathrm{MHz}, \mathrm{CDCl}_{3}\right) \delta$ 7.66-7.63 (m, 4H), 7.44-7.32 (m, 6H), 7.31-7.29 (m,2H), 7.23-7.21 (m, 2H), 6.88-6.82 (m, 4H), $5.60(\mathrm{~d}, J=$ 9.6 Hz, 1H), $5.34(\mathrm{~d}, J=10.1 \mathrm{~Hz}, 1 \mathrm{H}), 4.77(\mathrm{~A}$ of AB, $J=10.1 \mathrm{~Hz}, 1 \mathrm{H}), 4.43(\mathrm{~B}$ of AB, $J$ $=10.1 \mathrm{~Hz}, 1 \mathrm{H}), 4.54(\mathrm{~m}, 2 \mathrm{H}), 4.17(\mathrm{~d}, J=3.8 \mathrm{~Hz}, 1 \mathrm{H}), 4.09(\mathrm{~s}, 1 \mathrm{H}), 3.95-3.89(\mathrm{~m}, 1 \mathrm{H})$, 3.81-3.75 (m, 5H), $3.64(\mathrm{dd}, J=9.6 \mathrm{~Hz}, 1 \mathrm{H}), 3.56-3.50(\mathrm{~m}, 4 \mathrm{H}), 3.04-2.96(\mathrm{~m}, 1 \mathrm{H})$, 2.74-2.66 (m, 1H), 1.97-1.92 (m, 1H), $1.74(\mathrm{~s}, 3 \mathrm{H}), 1.53(\mathrm{~s}, 3 \mathrm{H}), 1.09$ (d, $J=6.5 \mathrm{~Hz}, 3 \mathrm{H})$, 1.07-1.03 (m, 33H), $1.00(\mathrm{~d}, J=6.3 \mathrm{~Hz}, 3 \mathrm{H}), 0.90-0.89(\mathrm{~m}, 12 \mathrm{H}), 0.76(\mathrm{~d}, J=6.9 \mathrm{~Hz}$, 3H), 0.062 (s, 3H), 0.043 (s, 3H); ${ }^{13} \mathrm{C}$ NMR (126 MHz, $\mathrm{CDCl}_{3}$ ) $\delta$ 159.3, 159.2, 135.82, $135.79,134.7,134.6,134.2,134.1,131.7,131.1,129.8,129.5,129.3,127.9,114.0,113.9$, 87.0, 83.4, 79.4, 79.2, 75.2, 73.1, 72.8, 66.9, 55.50, 55.48, 39.2, 37.8, 36.4, 35.3, 27.1, $26.1,19.5,18.41,18.36,18.2,17.84,17.77,16.1,14.1,12.7,10.8,7.7,-4.36,-4.45 ;$ IR (thin film, $\mathrm{NaCl}$ ) 3483, 2958, 2931, 2864, 1612, 1514, 1463, 1248, 1108, 1039, 842, 775, $701 \mathrm{~cm}^{-1}$; LRMS (EI, Na) calcd for $\mathrm{C}_{68} \mathrm{H}_{108} \mathrm{O}_{8} \mathrm{Si}_{3}, 1160.84 \mathrm{~m} / z(\mathrm{M}+\mathrm{Na}$ ); observed, $1144.02(\mathrm{M}+\mathrm{Na})^{+} \mathrm{m} / z$.

Data for minor diastereomer $(E, E)-(2 S, 3 S, 4 R, 7 S, 8 R, 9 R, 10 R, 13 S, 14 S)-1-(t e r t-$ butyldiphenylsilanyloxy)-3,9-di(p-methoxybenzyloxy)-13-(tri-isopropylsilanyloxy)14-(tert-butyldimethylsilanyloxy)-2,4,6,8,10,12-hexamethylpentadec-5,11-diene-7-ol, 7a”. $[\alpha]_{589}{ }^{20}+4.42{ }^{\circ}\left(c\right.$ 0.6, $\left.\mathrm{CHCl}_{3}\right) ;{ }^{1} \mathrm{H}$ NMR $\left(500 \mathrm{MHz}, \mathrm{CDCl}_{3}\right) \delta$ 7.66-7.63 (m, 4H), 
7.42-7.35 (m, 6H), 7.28-7.27 (m,2H), 7.21-7.19 (m, 2H), 6.84-6.83 (m, 4H), $5.68(\mathrm{~d}, J=$ $9.4 \mathrm{~Hz}, 1 \mathrm{H}), 5.21(\mathrm{~d}, J=10.0 \mathrm{~Hz}, 1 \mathrm{H}), 4.66-4.54(\mathrm{~m}, 4 \mathrm{H}), 4.17(\mathrm{~d}, J=3.9 \mathrm{~Hz}, 1 \mathrm{H}), 3.94-$ $3.91(\mathrm{~m}, 2 \mathrm{H}), 3.80(\mathrm{~s}, 3 \mathrm{H}), 3.79(\mathrm{~s}, 3 \mathrm{H}), 3.66-3.62(\mathrm{~m}, 2 \mathrm{H}), 3.53-3.50(\mathrm{~m}, 2 \mathrm{H}), 2.87-2.83$ (m, 1H), 2.74-2.65 (m, 1H), 2.00-1.91 (m, 1H), $1.74(\mathrm{~s}, 3 \mathrm{H}), 1.60(\mathrm{~s}, 3 \mathrm{H}), 1.10(\mathrm{~d}, J=6.7$ $\mathrm{Hz}, 3 \mathrm{H}), 1.08-1.05(\mathrm{~m}, 27 \mathrm{H}), 1.02(\mathrm{~d}, J=6.3 \mathrm{~Hz}, 3 \mathrm{H}), 0.98(\mathrm{~d}, J=6.9 \mathrm{~Hz}, 3 \mathrm{H}), 0.89(\mathrm{~m}$, $12 \mathrm{H}), 0.83(\mathrm{~d}, J=7.0 \mathrm{~Hz}, 3 \mathrm{H}), 0.78(\mathrm{~d}, J=6.9 \mathrm{~Hz}, 3 \mathrm{H}), 0.059(\mathrm{~s}, 3 \mathrm{H}), 0.041(\mathrm{~s}, 3 \mathrm{H}) ;{ }^{13} \mathrm{C}$ NMR (126 MHz, $\left.\mathrm{CDCl}_{3}\right) \delta 159.24,159.17,135.8,135.7,134.2,133.98,133.94,131.7$, $131.6,129.81,129.79,129.4,129.3,127.9,113.94,113.89,83.3,80.8,79.4,75.2,73.2$, $73.1,66.8,55.50,55.46,39.2,37.7,36.3,35.3,27.1,26.1,19.5,19.0,18.4,18.3,18.2$, 17.9, 15.7, 12.7, 12.3, 11.3, 10.5, -4.31, -4.42; IR (thin film, NaCl) 3487, 2930, 2863, $1613,1514,1463,1248,1108,1039,883,825,701,668 \mathrm{~cm}^{-1}$; LRMS (EI, Na) calcd for $\mathrm{C}_{68} \mathrm{H}_{108} \mathrm{O}_{8} \mathrm{Si}_{3}, 1160.87 \mathrm{~m} / z(\mathrm{M}+\mathrm{Na})$; observed, $1144.16(\mathrm{M}+\mathrm{Na})^{+} \mathrm{m} / z$.

Table 1. The role of a tethered free hydroxyl in titanium alkoxide-mediated reductive coupling reactions.

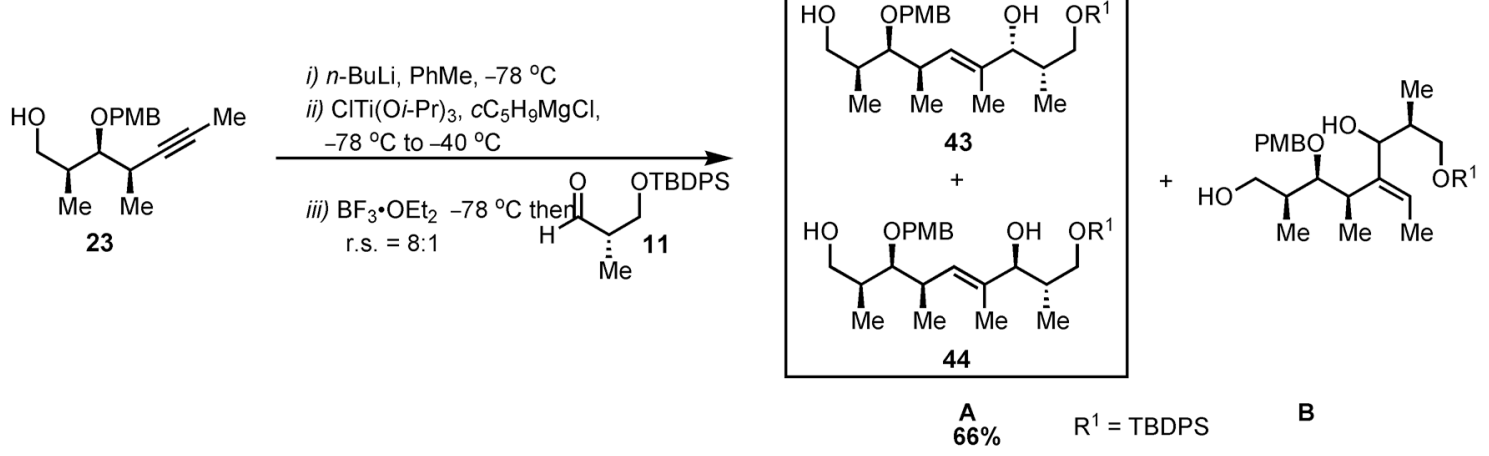

Entry 1 - synthesis of ene-diol 43 and 44 . To a $-78{ }^{\circ} \mathrm{C}$ solution of alkyne 23 (20 $\mathrm{mg}, 0.072 \mathrm{mmol})$ in $0.72 \mathrm{~mL}$ of toluene, was added sequentially, $n$-BuLi $(2.27 \mathrm{M}$ in hexanes; $35 \mu \mathrm{L}, 0.080 \mathrm{mmol}), \mathrm{ClTi}(\mathrm{O} i-\mathrm{Pr})_{3}(1.0 \mathrm{M}$ in hexanes; $160 \mu \mathrm{L}, 0.16 \mathrm{mmol})$ and 
$c-\mathrm{C}_{5} \mathrm{H}_{9} \mathrm{MgCl}(2.0 \mathrm{M}$ in diethyl ether; $160 \mu \mathrm{L}, 0.32 \mathrm{mmol})$ in a dropwise manner via a dry gas-tight syringe. The resulting yellow solution was slowly warmed to $-40{ }^{\circ} \mathrm{C}$ and stirred for $2 \mathrm{~h}$ during which the reaction turned dark brown. The flask was then cooled to $-78{ }^{\circ} \mathrm{C}$ and $\mathrm{BF}_{3} \bullet \mathrm{OEt}_{2}(29 \mu \mathrm{L}, 0.23 \mathrm{mmol})$ was added in a dropwise manner. Following a stirring period of $10 \mathrm{~min}$ at $-78{ }^{\circ} \mathrm{C}$, aldehyde $11(76 \mathrm{mg}, 0.23 \mathrm{mmol})$ was added as a solution in toluene $(0.2 \mathrm{~mL})$ down the side of the flask via a gas tight syringe. The transfer was quantitated with additional toluene $(2 \times 0.1 \mathrm{~mL})$. Stirring was maintained for $1 \mathrm{~h}$ at -78 ${ }^{\circ} \mathrm{C}$, before the addition of saturated $\mathrm{NH}_{4} \mathrm{Cl}$ solution $(0.4 \mathrm{~mL})$. The suspension was allowed to reach ambient temperature before partitioning between EtOAc $(5 \mathrm{~mL})$ and water $(3 \mathrm{~mL})$. The phases were separated and the aqueous layer was extracted with EtOAc $(3 \times 5 \mathrm{~mL})$. The combined organic layer was then washed with sat. $\mathrm{NaHCO}_{3}$ solution $(2 \times 10 \mathrm{~mL})$, brine $(1 \times 10 \mathrm{~mL})$ and dried over anhydrous $\mathrm{Na}_{2} \mathrm{SO}_{4}$. The crude material was purified by flash column chromatography eluting successively with $5 \%$ $(100 \mathrm{~mL}), 7 \%(50 \mathrm{~mL}), 10 \%(100 \mathrm{~mL}), 15 \%(50 \mathrm{~mL}), 20 \%(100 \mathrm{~mL})$ and $30 \%(200$ $\mathrm{mL}$ ) EtOAc/ hexanes to provide $29 \mathrm{mg}(66 \%)$ of $\mathbf{4 3}$ and $\mathbf{4 4}$ as the major regioisomer $\mathbf{A}$. Compound 44 was obtained with a small amount $(10 \%)$ of the minor regioisomer as contaminant. The amount of this contaminant was included in the yield reported.

Entry 1 - Regioselectivity data A:B. The residue obtained after a titanium reductive coupling using the above procedure was filtered through a short pad of silica eluting successively with $5 \%(50 \mathrm{~mL}), 7 \%(50 \mathrm{~mL}), 10 \%(50 \mathrm{~mL})$ and $15 \%(50 \mathrm{~mL})$ EtOAc/ hexanes until all traces of the partially reduced olefinic product of alkyne $\mathbf{2 3}$ were removed. All remaining organics were removed by washing the silica with $200 \mathrm{~mL}$ 
of $100 \%$ EtOAc. Analysis of the partially purified mixture by ${ }^{1} \mathrm{H}$ NMR shows an approximately 8:1 mixture of regioisomers.

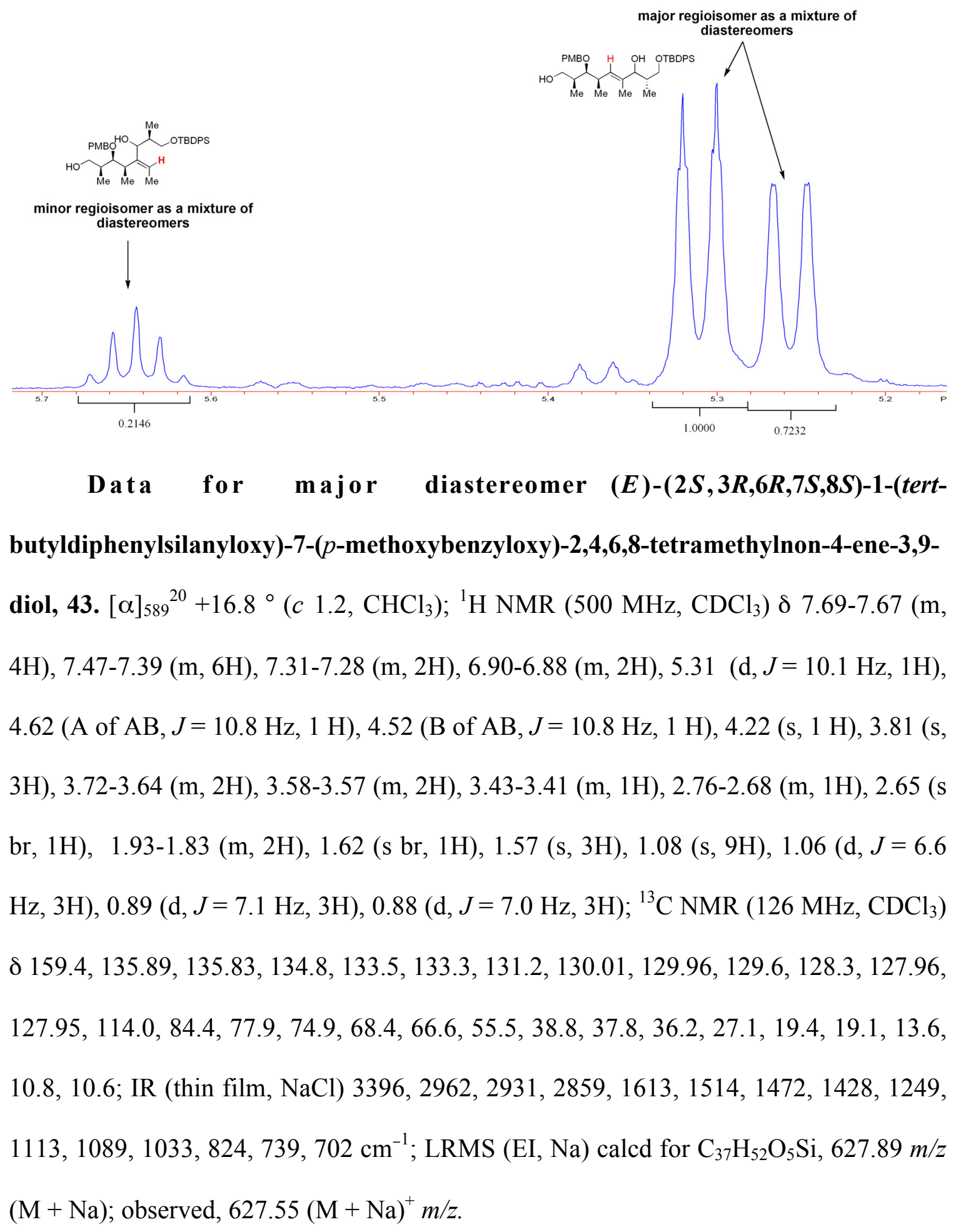


Data for minor diastereomer $(E)-(2 S, 3 S, 6 R, 7 S, 8 S)-1-(t e r t-$ butyldiphenylsilanyloxy)-7-( $p$-methoxybenzyloxy)-2,4,6,8-tetramethylnon-4-ene-3,9-

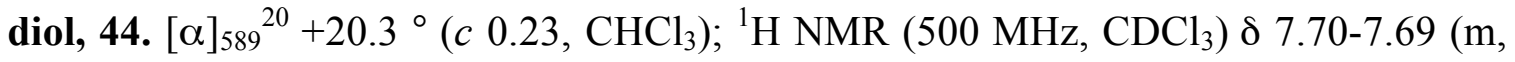
4H), 7.46-7.41 (m, 6H), 7.30-7.29 (m, 2H), 6.89-6.88 (m, 2H), 5.25 (d, $J=9.9 \mathrm{~Hz}, 1 \mathrm{H})$, $4.60(\mathrm{~A}$ of $\mathrm{AB}, J=10.8 \mathrm{~Hz}, 1 \mathrm{H}), 4.54(\mathrm{~B}$ of $\mathrm{AB}, J=10.8 \mathrm{~Hz}, 1 \mathrm{H}), 4.00(\mathrm{~s} b r, 1 \mathrm{H}), 3.91$ (d, $J=8.6 \mathrm{~Hz}, 1 \mathrm{H}), 3.81(\mathrm{~s}, 3 \mathrm{H}), 3.79$ (dd, $J=13.1,6.9 \mathrm{~Hz}, 1 \mathrm{H}), 3.67-3.63(\mathrm{~m}, 1 \mathrm{H}), 3.59-$ $3.53(\mathrm{~m}, 2 \mathrm{H}), 3.41(\mathrm{~d}, J=9.1 \mathrm{~Hz}, 1 \mathrm{H}), 2.77-2.72(\mathrm{~m}, 1 \mathrm{H}), 2.00-1.94(\mathrm{~m}, 1 \mathrm{H}), 1.88-1.82$ (m, 1H), $1.67(\mathrm{~s}, 3 \mathrm{H}), 1.13(\mathrm{~d}, J=6.6 \mathrm{~Hz}, 3 \mathrm{H}), 1.08(\mathrm{~s}, 9 \mathrm{H}), 0.86(\mathrm{~d}, J=7.0 \mathrm{~Hz}, 3 \mathrm{H})$, $0.65(\mathrm{~d}, J=6.9 \mathrm{~Hz}, 3 \mathrm{H}) ;{ }^{13} \mathrm{C} \mathrm{NMR}\left(126 \mathrm{MHz}, \mathrm{CDCl}_{3}\right) \delta 159.4,135.84,135.83,135.4$, $132.9,131.6,131.2,130.1,129.6,128.0,84.2,84.1,77.8,74.9,69.6,66.5,55.5,38.8$, 37.8, 36.3, 27.0, 19.3, 18.3, 13.8, 11.3, 10.8; IR (thin film, NaCl) 3422, 2959, 2931, 2857, 1612, 1514, 1463, 1428, 1248, 1036, 823, $741 \mathrm{~cm}^{-1}$; LRMS (EI, Na) calcd for $\mathrm{C}_{37} \mathrm{H}_{52} \mathrm{O}_{5} \mathrm{Si}, 627.89 \mathrm{~m} / z(\mathrm{M}+\mathrm{Na})$; observed, $627.51(\mathrm{M}+\mathrm{Na})^{+} \mathrm{m} / z$.
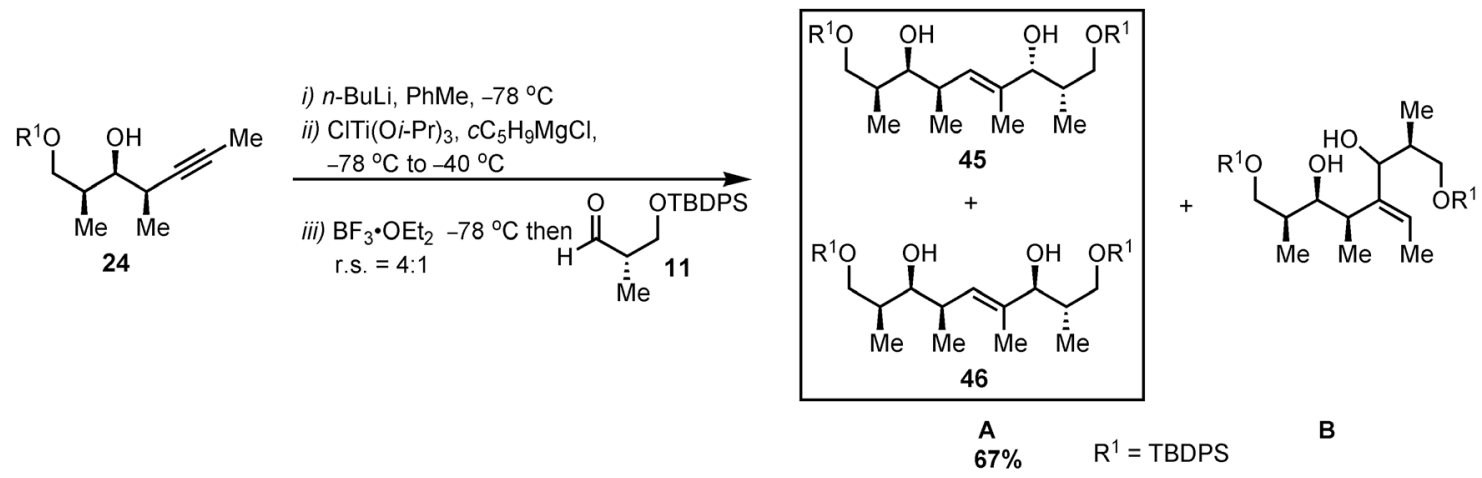

Entry 2 - synthesis of ene-1,5-diol 45 and 46 . To a $-78{ }^{\circ} \mathrm{C}$ solution of alkyne 47 (30 mg, $0.076 \mathrm{mmol})$ in $0.76 \mathrm{~mL}$ of toluene, was added sequentially, $n$-BuLi (2.27 M in hexanes; $37 \mu \mathrm{L}, 0.084 \mathrm{mmol}), \mathrm{ClTi}(\mathrm{O} i-\mathrm{Pr})_{3}(1.0 \mathrm{M}$ in hexanes; $170 \mu \mathrm{L}, 0.17 \mathrm{mmol})$ and $c-\mathrm{C}_{5} \mathrm{H}_{9} \mathrm{MgCl}(2.0 \mathrm{M}$ in diethyl ether; $170 \mu \mathrm{L}, 0.34 \mathrm{mmol})$ in a dropwise manner via a dry gas-tight syringe. The resulting yellow solution was slowly warmed to $-40{ }^{\circ} \mathrm{C}$ and stirred 
for $2 \mathrm{~h}$ during which the reaction turned dark brown. The flask was then cooled to $-78{ }^{\circ} \mathrm{C}$ and $\mathrm{BF}_{3} \bullet \mathrm{OEt}_{2}(31 \mu \mathrm{L}, 0.24 \mathrm{mmol})$ was added in a dropwise manner. Following a stirring period of $10 \mathrm{~min}$ at $-78{ }^{\circ} \mathrm{C}$, aldehyde $11(79 \mathrm{mg}, 0.24 \mathrm{mmol})$ was then added as a solution in toluene $(0.2 \mathrm{~mL})$ down the side of the flask via a gas tight syringe. The transfer was completed with additional toluene $(2 \times 0.1 \mathrm{~mL})$. Stirring was maintained for $1 \mathrm{~h}$ at $-78{ }^{\circ} \mathrm{C}$, before the addition of saturated $\mathrm{NH}_{4} \mathrm{Cl}$ solution $(0.4 \mathrm{~mL})$. The suspension was allowed to reach ambient temperature before partitioning between EtOAc $(5 \mathrm{~mL})$ and water $(3 \mathrm{~mL})$. The phases were separated and the aqueous layer was extracted with EtOAc $(3 \times 5 \mathrm{~mL})$. The combined organic layer was then washed with sat. $\mathrm{NaHCO}_{3}$ solution $(2 \times 10 \mathrm{~mL})$, brine $(1 \times 10 \mathrm{~mL})$ and dried over anhydrous $\mathrm{Na}_{2} \mathrm{SO}_{4}$. The crude material was purified by flash column chromatography eluting successively with $2 \%$ $(100 \mathrm{~mL}), 4 \%(100 \mathrm{~mL}), 7 \%(50 \mathrm{~mL}), 10 \%(50 \mathrm{~mL}), 15 \%(100 \mathrm{~mL})$ and $20 \%(100$ $\mathrm{mL})$ EtOAc/ hexanes to provide $37 \mathrm{mg}(67 \%)$ of $\mathbf{4 5}$ and $\mathbf{4 6}$ as the major regioisomer $\mathbf{A}$.

Entry 2 - Regioselectivity data A:B. The residue obtained after a titanium reductive coupling using the above procedure was filtered through a short pad of silica eluting successively with $2 \%(100 \mathrm{~mL}), 4 \%(50 \mathrm{~mL})$ and $6 \%(50 \mathrm{~mL})$ EtOAc/ hexanes until all traces of the partially reduced olefinic product of alkyne $\mathbf{2 4}$ were removed. All remaining organics were removed by washing the silica with $200 \mathrm{~mL}$ of $100 \%$ EtOAc. Analysis of the partially purified mixture by ${ }^{1} \mathrm{H}$ NMR shows an approximately $4: 1$ mixture of regioisomers.

Data for major diastereomer $(E)-(2 S, 3 R, 6 R, 7 S, 8 S)-1,9-d i(t e r t-$ butyldiphenylsilanyloxy)-2,4,6,8-tetramethylnon-4-ene-3,7-diol, $45 .[\alpha]_{589}{ }^{20}+9.3^{\circ}(c$ 0.84, $\left.\mathrm{CHCl}_{3}\right) ;{ }^{1} \mathrm{H} \mathrm{NMR}\left(500 \mathrm{MHz}, \mathrm{CDCl}_{3}\right) \delta$ 7.68-7.67 (m, 8H), 7.44-7.30 (m, 12H), 5.24 
$(\mathrm{d}, J=10.1 \mathrm{~Hz}, 1 \mathrm{H}), 4.23(\mathrm{~d}, J=3.0 \mathrm{~Hz}, 1 \mathrm{H}), 3.81(\mathrm{dd}, J=10.2,3.7 \mathrm{~Hz}, 1 \mathrm{H}), 3.72-3.63$ (m, 4H), 2.59-2.51 (m, 1H), 1.87-1.82 (m, 1H), 1.80-1.73 (m, 1H), $1.61(\mathrm{~s}, 3 \mathrm{H}), 1.075(\mathrm{~s}$, 9H), 1.068 (s, 9H), 1.05 (d, $J=6.6 \mathrm{~Hz}, 3 \mathrm{H}), 0.93(\mathrm{~d}, J=7.1 \mathrm{~Hz}, 3 \mathrm{H}), 0.82(\mathrm{~d}, J=7.0 \mathrm{~Hz}$, $3 \mathrm{H}) ;{ }^{13} \mathrm{C} \mathrm{NMR}\left(126 \mathrm{MHz}, \mathrm{CDCl}_{3}\right) \delta 136.0,135.89,135.85,135.8,135.1,133.5,133.4$, $133.2,130.1,130.01,129.98,128.00,127.97,127.96,127.94,127.88,127.7,78.8,77.7$, $70.0,68.4,37.7,37.2,36.5,27.13,27.11,19.43,19.42,18.0,13.8,10.4,9.6$; IR (thin film, $\mathrm{NaCl}) 3471,2959,2930,2858,1472,1427,1113,998,823,740,701,614 \mathrm{~cm}^{-1}$; LRMS (EI, Na) calcd for $\mathrm{C}_{45} \mathrm{H}_{62} \mathrm{O}_{4} \mathrm{Si}_{2}, 746.14 \mathrm{~m} / z(\mathrm{M}+\mathrm{Na})$; observed, $746.72(\mathrm{M}+$ $\mathrm{Na})^{+} m / z$.

Data for minor diastereomer $(E)-(2 S, 3 S, 6 R, 7 S, 8 S)-1,9-d i(t e r t-$ butyldiphenylsilanyloxy)-2,4,6,8-tetramethylnon-4-ene-3,7-diol, $46 .[\alpha]_{589}{ }^{20}+12.5^{\circ}(\mathrm{c}$ 1.3, $\left.\mathrm{CHCl}_{3}\right) ;{ }^{1} \mathrm{H}$ NMR $\left(500 \mathrm{MHz}, \mathrm{CDCl}_{3}\right) \delta$ 7.69-7.65 (m, 8H), 7.49-7.380 (m, 12H), 5.13 (d, $J=10.1 \mathrm{~Hz}, 1 \mathrm{H}), 3.87(\mathrm{~d}, J=8.7 \mathrm{~Hz}, 1 \mathrm{H}), 3.78-3.76(\mathrm{~m}, 2 \mathrm{H}), 3.67-3.61(\mathrm{~m}, 3 \mathrm{H})$, 2.60-2.52 (m, 1H), 1.98-1.93 (m, 1H), 1.72-1.63 (m, 1H), $1.67(\mathrm{~s}, 3 \mathrm{H}), 1.11(\mathrm{~d}, J=6.5$ $\mathrm{Hz}, 3 \mathrm{H}), 1.07$ (s, 18H), 0.91 (d, $J=7.0 \mathrm{~Hz}, 3 \mathrm{H}), 0.59$ (d, $J=7.2 \mathrm{~Hz}, 3 \mathrm{H}) ;{ }^{13} \mathrm{C}$ NMR (126 $\left.\mathrm{MHz}, \mathrm{CDCl}_{3}\right) \delta 135.9,135.83,135.8,135.6,133.3,133.1,133.94,132.92,131.3,130.11$, $130.10,130.06,130.01,128.00,127.98,127.97,84.2,78.6,69.8,69.6,37.6,37.3,36.6$, 27.1, 27.01, 19.4, 19.3, 17.0, 13.7, 11.3, 9.5; IR (thin film, NaCl) 3472, 2958, 2930, $2857,1427,1112,740,701 \mathrm{~cm}^{-1}$; LRMS (EI, Na) calcd for $\mathrm{C}_{45} \mathrm{H}_{62} \mathrm{O}_{4} \mathrm{Si}_{2}, 746.14 \mathrm{~m} / z$ (M $+\mathrm{Na})$; observed, $746.63(\mathrm{M}+\mathrm{Na})^{+} \mathrm{m} / z$. 

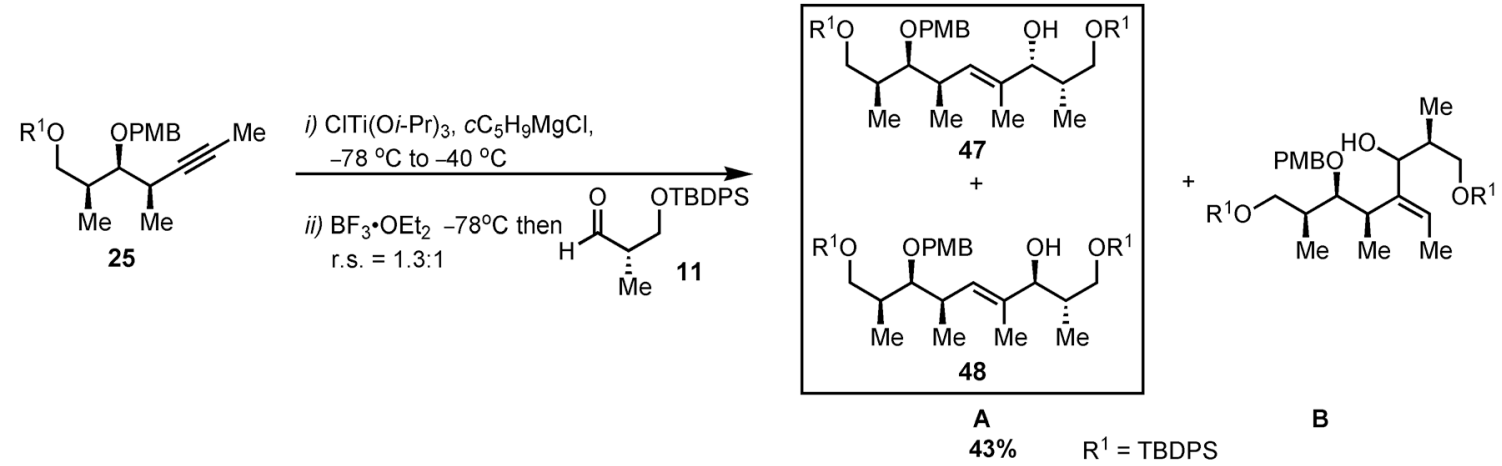

Entry 3 - synthesis of enol 47 and 48 . To a $-78{ }^{\circ} \mathrm{C}$ solution of alkyne 25 (35 $\mathrm{mg}$, $0.068 \mathrm{mmol})$ in $0.68 \mathrm{~mL}$ of toluene, was added sequentially, $\mathrm{ClTi}(\mathrm{O} i-\mathrm{Pr})_{3}(1.0 \mathrm{M}$ in hexanes; $150 \mu \mathrm{L}, 0.15 \mathrm{mmol})$ and $c-\mathrm{C}_{5} \mathrm{H}_{9} \mathrm{MgCl}(2.0 \mathrm{M}$ in diethyl ether; $150 \mu \mathrm{L}, 0.30$ mmol) in a dropwise manner via a dry gas-tight syringe. The resulting yellow solution was slowly warmed to $-40{ }^{\circ} \mathrm{C}$ and stirred for $2 \mathrm{~h}$ during which the reaction turned dark brown. The flask was then cooled to $-78^{\circ} \mathrm{C}$ and $\mathrm{BF}_{3} \bullet \mathrm{OEt}_{2}(19 \mu \mathrm{L}, 0.15 \mathrm{mmol})$ was added in a dropwise manner. Following a stirring period of $10 \mathrm{~min}$ at $-78^{\circ} \mathrm{C}$, aldehyde $11(71 \mathrm{mg}, 0.22 \mathrm{mmol})$ was then added as a solution in toluene $(0.2 \mathrm{~mL})$ down the side of the flask via a gas tight syringe. The transfer was completed with additional toluene $(2 \times$ $0.1 \mathrm{~mL}$ ). Stirring was maintained for $1 \mathrm{~h}$ at $-78{ }^{\circ} \mathrm{C}$, before the addition of saturated $\mathrm{NH}_{4} \mathrm{Cl}$ solution $(0.4 \mathrm{~mL})$. The suspension was allowed to reach ambient temperature before partitioning between EtOAc $(5 \mathrm{~mL})$ and water $(3 \mathrm{~mL})$. The phases were separated and the aqueous layer was extracted with EtOAc $(3 \times 5 \mathrm{~mL})$. The combined organic layer was then washed with sat. $\mathrm{NaHCO}_{3}$ solution $(2 \times 10 \mathrm{~mL})$, brine $(1 \times 10 \mathrm{~mL})$ and dried over anhydrous $\mathrm{Na}_{2} \mathrm{SO}_{4}$. The crude material was purified by flash column chromatography eluting successively with $2 \%(100 \mathrm{~mL}), 4 \%(100 \mathrm{~mL}), 7 \%(100 \mathrm{~mL})$, $10 \%(50 \mathrm{~mL}), 15 \%(100 \mathrm{~mL})$ and $20 \%(100 \mathrm{~mL})$ EtOAc/ hexanes to provide $24 \mathrm{mg}(43$ $\%)$ of $\mathbf{4 7}$ and 48 as the major regioisomer $\mathrm{A}$. 
Entry 3 - Regioselectivity data A:B. The residue obtained after a titanium reductive coupling using the above procedure was filtered through a short pad of silica eluting successively with $2 \%(100 \mathrm{~mL})$ and $4 \%(50 \mathrm{~mL})$ EtOAc/ hexanes until all traces of the partially reduced olefinic product of alkyne 25 were removed. All remaining organics were removed by washing the silica with $200 \mathrm{~mL}$ of $100 \%$ EtOAc. Analysis of the partially purified mixture by ${ }^{1} \mathrm{H}$ NMR shows an approximately $1.3: 1$ mixture of regioisomers.

Data for major diastereomer $(E)-(2 S, 3 R, 6 R, 7 S, 8 S)-1,9-d i(t e r t-$ butyldiphenylsilanyloxy)- 7-(p-methoxybenzyloxy)-2,4,6,8-tetramethylnon-4-ene-3,7diol, 47. $[\alpha]_{589}{ }^{20}+9.21^{\circ}\left(c \quad 0.89, \mathrm{CHCl}_{3}\right) ;{ }^{1} \mathrm{H}$ NMR $\left(500 \mathrm{MHz}, \mathrm{CDCl}_{3}\right) \delta$ 7.68-7.66 (m, $8 \mathrm{H}), 7.42-7.38(\mathrm{~m}, 12 \mathrm{H}), 7.22-7.20(\mathrm{~m}, 2 \mathrm{H}), 6.85-6.83(\mathrm{~m}, 2 \mathrm{H}), 5.33(\mathrm{~d}, J=10.1 \mathrm{~Hz}$, $1 \mathrm{H}), 4.54(\mathrm{~s}, 2 \mathrm{H}), 4.23,(\mathrm{~s}, 1 \mathrm{H}), 3.80(\mathrm{~s}, 3 \mathrm{H}), 3.74-3.61(\mathrm{~m}, 3 \mathrm{H}), 3.57-3.51(\mathrm{~m}, 2 \mathrm{H}), 2.72-$ $2.65(\mathrm{~m}, 1 \mathrm{H}), 1.98-1.91(\mathrm{~m}, 1 \mathrm{H}), 1.90-1.82(\mathrm{~m}, 1 \mathrm{H}), 1.57(\mathrm{~s}, 3 \mathrm{H}), 1.09(\mathrm{~s}, 9 \mathrm{H}), 1.06(\mathrm{~s}$, $9 \mathrm{H}), 1.05(\mathrm{~d}, J=6.7 \mathrm{~Hz}, 3 \mathrm{H}), 0.91(\mathrm{~d}, J=6.8 \mathrm{~Hz}, 3 \mathrm{H}), 0.78(\mathrm{~d}, J=6.8 \mathrm{~Hz}, 3 \mathrm{H}) ;{ }^{13} \mathrm{C}$ NMR $\left(126 \mathrm{MHz}, \mathrm{CDCl}_{3}\right) \delta 159.2,135.9,135.84,135.82,135.80,134.7,134.2,134.1$, $133.6,133.4,131.7,130.00,129.97,129.8,129.5,128.4,127.96,127.95,127.87,127.85$, $113.9,83.3,77.9,75.2,68.4,66.9,55.5,39.2,37.8,36.3,27.15,27.12,19.51,19.46,18.3$, 13.7, 10.5, 10.4; IR (thin film, NaCl) 3496, 2962, 2859, 1427, 1248, 1112, 740, $701 \mathrm{~cm}^{-1}$; LRMS (EI, Na) calcd for $\mathrm{C}_{53} \mathrm{H}_{70} \mathrm{O}_{5} \mathrm{Si}_{2}, 866.29 \mathrm{~m} / z(\mathrm{M}+\mathrm{Na})$; observed, $866.72(\mathrm{M}+$ $\mathrm{Na})^{+} m / z$.

Dat a for minor diastereomer $(E)-(2 S, 3 S, 6 R, 7 S, 8 S)-1,9-d i(t e r t-$ butyldiphenylsilanyloxy) -7-( $p$-methoxybenzyloxy)-2,4,6,8-tetramethylnon-4-ene-3,7diol, 48. $[\alpha]_{589}{ }^{20}+19.6^{\circ}\left(c \quad 0.7, \mathrm{CHCl}_{3}\right) ;{ }^{1} \mathrm{H} \mathrm{NMR}\left(500 \mathrm{MHz}, \mathrm{CDCl}_{3}\right) \delta$ 7.72-7.63 (m, 
8H), 7.45-7.33 (m, 12H), 7.22-7.20 (m, 2H), 6.85-6.84 (m, 2H), $5.22(\mathrm{~d}, J=10.0 \mathrm{~Hz}$, $1 \mathrm{H}), 4.55(\mathrm{~s}, 2 \mathrm{H}), 3.98,(\mathrm{~s}, 1 \mathrm{H}), 3.92(\mathrm{~d}, J=8.9 \mathrm{~Hz}, 1 \mathrm{H}), 3.80(\mathrm{~s}, 3 \mathrm{H}), 3.70-3.62(\mathrm{~m}, 2 \mathrm{H})$, 3.55-3.49 (m, 2H), 2.74-2.68 (m, 1H), 2.01-1.93 (m, 1H), 1.91-1.84 (m, 1H), $1.66(\mathrm{~s}$, $3 \mathrm{H}), 1.12(\mathrm{~d}, J=6.5 \mathrm{~Hz}, 3 \mathrm{H}), 1.08$ (s, 9H), $1.06(\mathrm{~s}, 9 \mathrm{H}), 0.76(\mathrm{~d}, J=6.8 \mathrm{~Hz}, 3 \mathrm{H}), 0.62$ (d, $J=6.9 \mathrm{~Hz}, 3 \mathrm{H}) ;{ }^{13} \mathrm{C}$ NMR $\left(126 \mathrm{MHz}, \mathrm{CDCl}_{3}\right) \delta 159.2,135.85,135.78,135.74,135.2$, 134.1, 133.03, 132.99, 132.1, 131.6, 130.1, 129.80, 129.78, 129.4, 128.05, 128.04, 127.9, $127.8,113.9,84.4,83.2,75.3,69.8,66.8,55.5,39.2,37.8,36.3,27.1,27.0,19.5,19.3$, 18.3, 13.7, 11.1, 10.4; IR (thin film, NaCl) 3492, 2960, 2931, 2858, 1514, 1472, 1428, $1248,1112,1038,823,740,701,614 \mathrm{~cm}^{-1}$; LRMS (EI, Na) calcd for $\mathrm{C}_{53} \mathrm{H}_{70} \mathrm{O}_{5} \mathrm{Si}_{2}$, $866.29 \mathrm{~m} / z(\mathrm{M}+\mathrm{Na})$; observed, $866.72(\mathrm{M}+\mathrm{Na})^{+} \mathrm{m} / \mathrm{z}$.
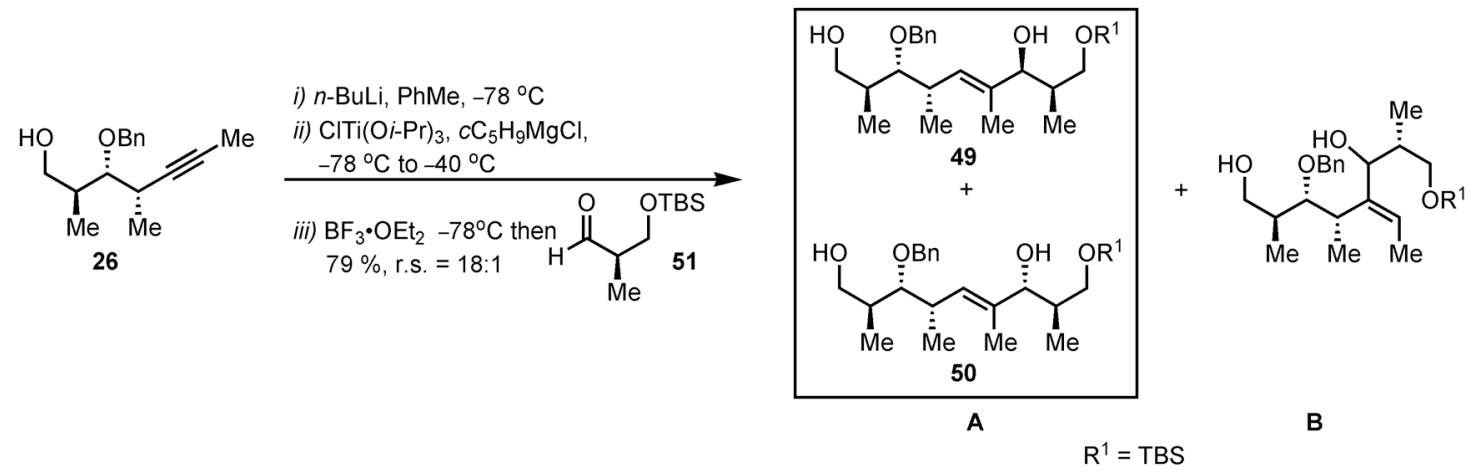

Entry 4 - synthesis of ene-diol 49 and 50. To a $-78{ }^{\circ} \mathrm{C}$ solution of alkyne 26 (20 $\mathrm{mg}, 0.081 \mathrm{mmol})$ in $0.81 \mathrm{~mL}$ of toluene, was added sequentially, $n$-BuLi $(2.27 \mathrm{M}$ in hexanes; $39 \mu \mathrm{L}, 0.089 \mathrm{mmol}), \mathrm{ClTi}(\mathrm{O} i-\mathrm{Pr})_{3}(1.0 \mathrm{M}$ in hexanes; $180 \mu \mathrm{L}, 0.18 \mathrm{mmol})$ and ${ }^{c}-\mathrm{C}_{5} \mathrm{H}_{9} \mathrm{MgCl}(2.0 \mathrm{M}$ in diethyl ether; $180 \mu \mathrm{L}, 0.36 \mathrm{mmol})$ in a dropwise manner via a dry gas-tight syringe. The resulting yellow solution was slowly warmed to $-40{ }^{\circ} \mathrm{C}$ and stirred for $2 \mathrm{~h}$ during which the reaction turned dark brown. The flask was then cooled to $-78{ }^{\circ} \mathrm{C}$ and $\mathrm{BF}_{3} \cdot \mathrm{OEt}_{2}(33 \mu \mathrm{L}, 0.260 \mathrm{mmol})$ was added in a dropwise manner. Following a stirring period of $10 \mathrm{~min}$ at $-78{ }^{\circ} \mathrm{C}$, aldehyde $\mathbf{5 1}(53 \mathrm{mg}, 0.26 \mathrm{mmol})$ was then added as a 
solution in toluene $(0.2 \mathrm{~mL})$ down the side of the flask via a gas tight syringe. The transfer was completed with additional toluene $(2 \times 0.1 \mathrm{~mL})$. Stirring was maintained for $1 \mathrm{~h}$ at $-78{ }^{\circ} \mathrm{C}$, before the addition of saturated $\mathrm{NH}_{4} \mathrm{Cl}$ solution $(0.4 \mathrm{~mL})$. The suspension was allowed to reach ambient temperature before partitioning between EtOAc $(5 \mathrm{~mL})$ and water $(3 \mathrm{~mL})$. The phases were separated and the aqueous layer was extracted with EtOAc $(3 \times 5 \mathrm{~mL})$. The combined organic layer was then washed with sat. $\mathrm{NaHCO}_{3}$ solution $(2 \times 10 \mathrm{~mL})$, brine $(1 \times 10 \mathrm{~mL})$ and dried over anhydrous $\mathrm{Na}_{2} \mathrm{SO}_{4}$. The crude material was purified by flash column chromatography eluting successively with $5 \%$ $(100 \mathrm{~mL}), 7 \%(50 \mathrm{~mL}), 10 \%(100 \mathrm{~mL}), 15 \%(50 \mathrm{~mL}), 20 \%(100 \mathrm{~mL})$ and $30 \%(200$ $\mathrm{mL}) \mathrm{EtOAc} /$ hexanes to provide $29 \mathrm{mg}(79 \%)$ of an inseparable mixture of regioisomers A and $\mathbf{B}$.

Entry 4 - Regioselectivity data A:B. The residue obtained after a titanium reductive coupling using the above procedure was filtered through a short pad of silica eluting successively with $5 \%(100 \mathrm{~mL}), 7 \%(50 \mathrm{~mL}), 10 \%(50 \mathrm{~mL})$ and $15 \%(50 \mathrm{~mL})$ EtOAc/ hexanes until all traces of the partially reduced olefinic product of alkyne $\mathbf{2 6}$ were removed. All remaining organics were removed by washing the silica with $200 \mathrm{~mL}$ of $100 \%$ EtOAc. Analysis of the partially purified mixture by ${ }^{1} \mathrm{H}$ NMR shows an approximately 18:1 mixture of regioisomers. 


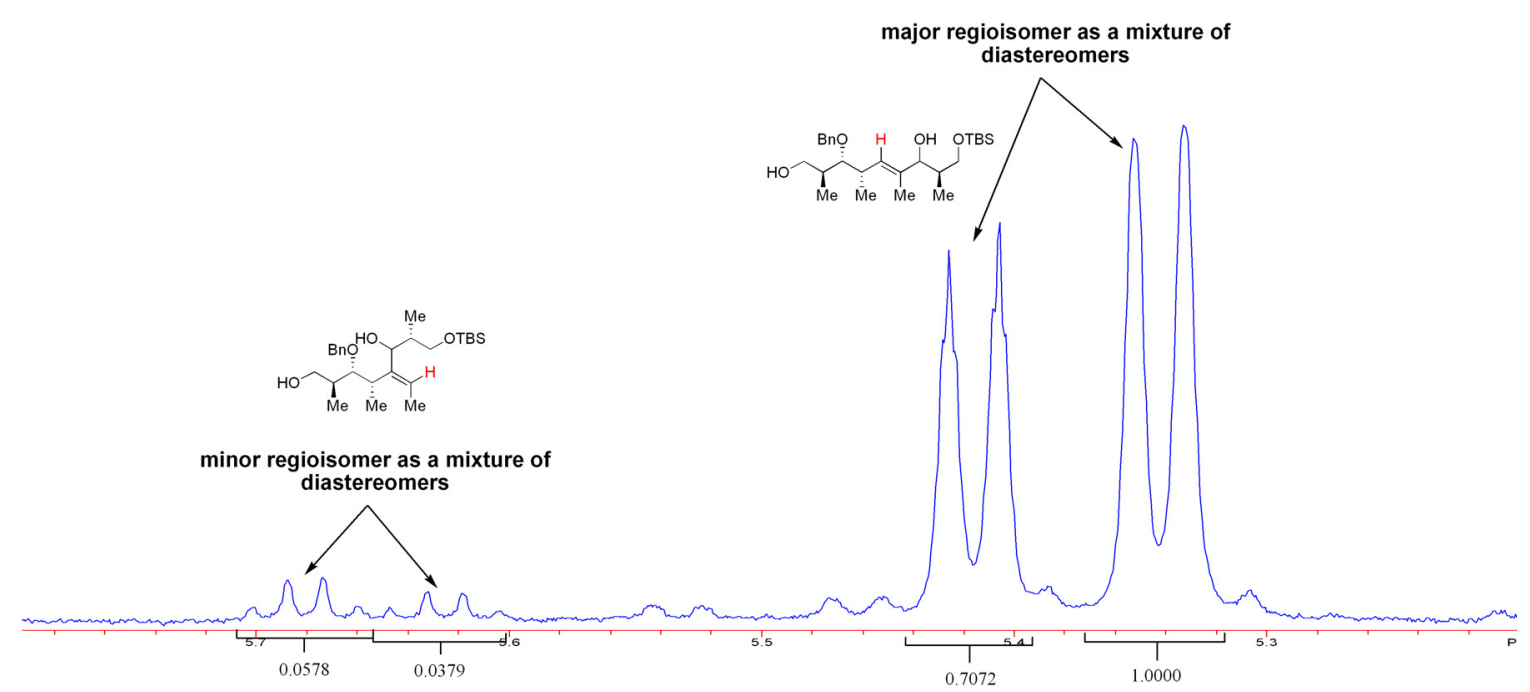

Data for major diastereomer $(E)-(2 R, 3 S, 6 S, 7 R, 8 S)-1-($ tertbutyldimethylsilanyloxy)-7-(benzyloxy)-2,4,6,8-tetramethylnon-4-ene-3,9-diol, 49. $[\alpha]_{589}{ }^{20}-22.3^{\circ}\left(c\right.$ 1.37, $\left.\mathrm{CHCl}_{3}\right) ;{ }^{1} \mathrm{H}$ NMR $\left(500 \mathrm{MHz}, \mathrm{CDCl}_{3}\right) \delta$ 7.37-7.29 (m, 5H), 5.34 $(\mathrm{d}, J=9.8 \mathrm{~Hz}, 1 \mathrm{H}), 4.66(\mathrm{~A}$ of $\mathrm{AB}, J=10.8 \mathrm{~Hz}, 1 \mathrm{H}), 4.59(\mathrm{~B}$ of $\mathrm{AB}, J=10.8 \mathrm{~Hz}, 1 \mathrm{H})$, 4.14 (s br, $1 \mathrm{H}), 3.85$ (d, $J=8.2 \mathrm{~Hz}, 1 \mathrm{H}), 3.81-3.76(\mathrm{~m}, 2 \mathrm{H}), 3.62-3.54(\mathrm{~m}, 2 \mathrm{H}), 3.27$ (dd, $J=6.5,5.1 \mathrm{~Hz}, 1 \mathrm{H}), 2.85-2.77(\mathrm{~m}, 1 \mathrm{H}), 2.76-2.60(\mathrm{~s} \mathrm{br}, 1 \mathrm{H}), 1.94-1.83(\mathrm{~m}, 2 \mathrm{H}), 1.66(\mathrm{~d}$, $J=0.73 \mathrm{~Hz}, 3 \mathrm{H}), 1.11(\mathrm{~d}, J=6.7 \mathrm{~Hz}, 3 \mathrm{H}), 1.09(\mathrm{~d}, J=7.2 \mathrm{~Hz}, 3 \mathrm{H}), 0.92(\mathrm{~s}, 9 \mathrm{H}), 0.71(\mathrm{~d}$, $J=7.0 \mathrm{~Hz}, 3 \mathrm{H}), 0.10(\mathrm{~s}, 6 \mathrm{H}) ;{ }^{13} \mathrm{C} \mathrm{NMR}\left(126 \mathrm{MHz}, \mathrm{CDCl}_{3}\right) \delta 138.4,135.9,131.4,128.7$, $128.05,127.98,89.9,84.2,76.0,68.9,65.7,37.7,37.5,36.3,26.0,18.3,16.8,16.0,13.9$, 11.7, -5.4, -5.5; IR (thin film, NaCl) 3425, 2958, 2929, 2858, 1471, 1456, 1253, 1089, 1005, 836, 777, $697 \mathrm{~cm}^{-1}$; LRMS (EI, Na) calcd for $\mathrm{C}_{26} \mathrm{H}_{46} \mathrm{O}_{4} \mathrm{Si}, 473.73 \mathrm{~m} / z(\mathrm{M}+\mathrm{Na})$; observed, $473.49(\mathrm{M}+\mathrm{Na})^{+} m / z$.

Data for minor diastereomer $(E)-(2 R, 3 R, 6 S, 7 R, 8 S)-1-($ tertbutyldimethylsilanyloxy)-7-(benzyloxy)-2,4,6,8-tetramethylnon-4-ene-3,9-diol, 50. $[\alpha]_{589}{ }^{20}-17.7^{\circ}\left(c 0.9, \mathrm{CHCl}_{3}\right) ;{ }^{1} \mathrm{H}$ NMR $\left(500 \mathrm{MHz}, \mathrm{CDCl}_{3}\right) \delta$ 7.36-7.29 (m, 5H), $5.42(\mathrm{~d}$, 
$J=9.9 \mathrm{~Hz}, 1 \mathrm{H}), 4.68(\mathrm{~A}$ of AB, $J=10.8 \mathrm{~Hz}, 1 \mathrm{H}), 4.61(\mathrm{~B}$ of AB, $J=10.8 \mathrm{~Hz}, 1 \mathrm{H}), 4.19$ (s, $1 \mathrm{H}), 3.80(\mathrm{~d}, J=10.8 \mathrm{~Hz}, 1 \mathrm{H}), 3.76(\mathrm{dd}, J=9.9,4.0 \mathrm{~Hz}, 1 \mathrm{H}), 3.68(\mathrm{dd}, J=9.8,4.6$ Hz, 1H), 3.55-3.53 (m, 1H), 3.30 (dd, $J=7.1,4.6 \mathrm{~Hz}, 1 \mathrm{H}), 3.07$ (s br, $1 \mathrm{H}), 2.85-2.78$ (m, 1H), 2.75 (s br, 1H), 1.93-1.82 (m, 2H), $1.60(\mathrm{~s}, 3 \mathrm{H}), 1.11(\mathrm{~d}, J=2.65 \mathrm{~Hz}, 3 \mathrm{H}), 1.10$ (d, $J=2.15 \mathrm{~Hz}, 3 \mathrm{H}), 0.92(\mathrm{~s}, 9 \mathrm{H}), 0.84(\mathrm{~d}, J=7.0 \mathrm{~Hz}, 3 \mathrm{H}), 0.085(\mathrm{~s}, 3 \mathrm{H}), 0.080(\mathrm{~s}, 3 \mathrm{H}) ;{ }^{13} \mathrm{C}$ NMR (126 MHz, $\left.\mathrm{CDCl}_{3}\right) \delta 138.4,135.0,128.7,128.07,128.05,90.2,78.3,76.2,68.3$, $65.6,37.6,37.4,36.5,26.1,18.4,17.1,16.1,14.0,10.3,-5.35,-5.39$; IR (thin film, $\mathrm{NaCl}) 3410,2957,2929,2857,1471,1454,1256,1094,1028,836,777,698 \mathrm{~cm}^{-1}$; LRMS (EI, Na) calcd for $\mathrm{C}_{26} \mathrm{H}_{46} \mathrm{O}_{4} \mathrm{Si}, 473.73 \mathrm{~m} / z(\mathrm{M}+\mathrm{Na})$; observed, $473.49(\mathrm{M}+\mathrm{Na})^{+}$ $m / z$.
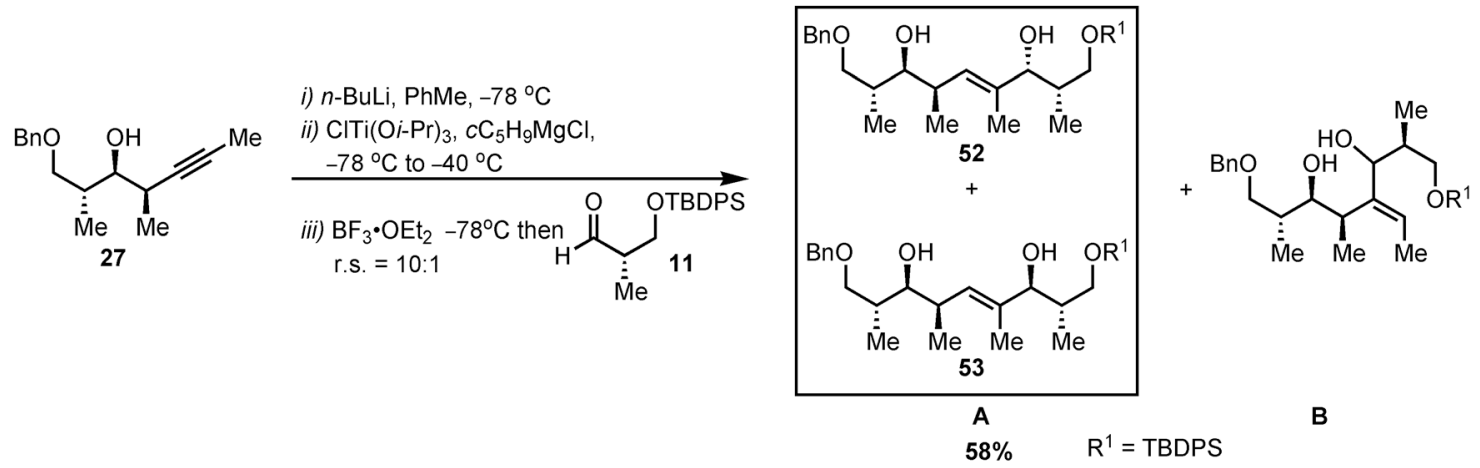

Entry 5 - synthesis of ene-1,5-diol 52 and 53. To a $-78{ }^{\circ} \mathrm{C}$ solution of alkyne 27 (20 mg, $0.081 \mathrm{mmol}$ ) in $0.81 \mathrm{~mL}$ of toluene, was added sequentially, $n$-BuLi (2.27 M in hexanes; $39 \mu \mathrm{L}, 0.089 \mathrm{mmol}), \mathrm{ClTi}(\mathrm{O} i-\mathrm{Pr})_{3}(1.0 \mathrm{M}$ in hexanes; $180 \mu \mathrm{L}, 0.18 \mathrm{mmol})$ and $c-\mathrm{C}_{5} \mathrm{H}_{9} \mathrm{MgCl}(2.0 \mathrm{M}$ in diethyl ether; $180 \mu \mathrm{L}, 0.36 \mathrm{mmol})$ in a dropwise manner via a dry gas-tight syringe. The resulting yellow solution was slowly warmed to $-40{ }^{\circ} \mathrm{C}$ and stirred for $2 \mathrm{~h}$ during which the reaction turned dark brown. The flask was then cooled to $-78{ }^{\circ} \mathrm{C}$ and $\mathrm{BF}_{3} \bullet \mathrm{OEt}_{2}(33 \mu \mathrm{L}, 0.26 \mathrm{mmol})$ was added in a dropwise manner. Following a stirring period of $10 \mathrm{~min}$ at $-78{ }^{\circ} \mathrm{C}$, aldehyde $11(85 \mathrm{mg}, 0.26 \mathrm{mmol})$ was then added as a 
solution in toluene $(0.2 \mathrm{~mL})$ down the side of the flask via a gas tight syringe. The transfer was completed with additional toluene $(2 \times 0.1 \mathrm{~mL})$. Stirring was maintained for $1 \mathrm{~h}$ at $-78{ }^{\circ} \mathrm{C}$, before the addition of saturated $\mathrm{NH}_{4} \mathrm{Cl}$ solution $(0.4 \mathrm{~mL})$. The suspension was allowed to reach ambient temperature before partitioning between EtOAc $(5 \mathrm{~mL})$ and water $(3 \mathrm{~mL})$. The phases were separated and the aqueous layer was extracted with EtOAc $(3 \times 5 \mathrm{~mL})$. The combined organic layer was then washed with sat. $\mathrm{NaHCO}_{3}$ solution $(2 \times 10 \mathrm{~mL})$, brine $(1 \times 10 \mathrm{~mL})$ and dried over anhydrous $\mathrm{Na}_{2} \mathrm{SO}_{4}$. The crude material was purified by flash column chromatography eluting successively with $2 \%$ $(100 \mathrm{~mL}), 4 \%(100 \mathrm{~mL}), 7 \%(50 \mathrm{~mL}), 10 \%(50 \mathrm{~mL}), 15 \%(100 \mathrm{~mL})$ and $20 \%(200$ $\mathrm{mL}$ ) EtOAc/ hexanes to provide $27 \mathrm{mg}$ (58 \%) of $\mathbf{5 2}$ and $\mathbf{5 3}$ as the major regioisomer $\mathbf{A}$.

Entry 5 - Regioselectivity data A:B. The residue obtained after a titanium reductive coupling using the above procedure was filtered through a short pad of silica eluting successively with $2 \%(100 \mathrm{~mL}), 4 \%(50 \mathrm{~mL})$ and $6 \%(50 \mathrm{~mL})$ EtOAc/ hexanes until all traces of the partially reduced olefinic product alkyne 27 were removed. All remaining organics were removed by washing the silica with $200 \mathrm{~mL}$ of $100 \%$ EtOAc. Analysis of the partially purified mixture by ${ }^{1} \mathrm{H}$ NMR shows an approximately 10:1 mixture of regioisomers.

Data for $(E)-(2 R, 3 S, 6 R, 7 S, 8 R)-1,9-d i(b e n z y l o x y)-2,4,6,8-t e t r a m e t h y l n o n-4-$ ene-3,7-diol, 52. $[\alpha]_{589}{ }^{20}+29.6^{\circ}\left(c \quad 0.73, \mathrm{CHCl}_{3}\right) ;{ }^{1} \mathrm{H} \mathrm{NMR}\left(500 \mathrm{MHz}, \mathrm{CDCl}_{3}\right) \delta$ 7.70$7.68(\mathrm{~m}, 4 \mathrm{H}), 7.68-7.28(\mathrm{~m}, 11 \mathrm{H}), 5.33(\mathrm{~d}, J=9.6 \mathrm{~Hz}, 1 \mathrm{H}), 4.53(\mathrm{~A}$ of AB, $J=12.0 \mathrm{~Hz}$, $1 \mathrm{H}), 4.48(\mathrm{~B}$ of AB, $J=12.0 \mathrm{~Hz}, 1 \mathrm{H}), 3.91-3.90(\mathrm{~m}, 2 \mathrm{H}), 3.78(\mathrm{dd}, J=10.1,4.1 \mathrm{~Hz}$, 1H), $3.64(\mathrm{dd}, J=10.1,7.9 \mathrm{~Hz}, 1 \mathrm{H}), 3.61(\mathrm{dd}, J=9.2,4.2 \mathrm{~Hz}, 1 \mathrm{H}), 3.43(\mathrm{dd}, J=9.0,5.2$ $\mathrm{Hz}, 1 \mathrm{H}), 3.28(\mathrm{dd}, J=12.0,6.0 \mathrm{~Hz}, 1 \mathrm{H}), 3.03(\mathrm{~d}, J=6.1 \mathrm{~Hz}, 1 \mathrm{H}), 2.55-2.48(\mathrm{~m}, 1 \mathrm{H})$, 
1.97-1.82 (m, 2H), $1.58(\mathrm{~d}, J=1.1 \mathrm{~Hz}, 3 \mathrm{H}), 1.07$ (s, 9H), $1.06(\mathrm{~d}, J=2.3 \mathrm{~Hz}, 3 \mathrm{H}), 1.04$ $(\mathrm{d}, J=2.8 \mathrm{~Hz}, 3 \mathrm{H}), 0.63(\mathrm{~d}, J=6.9 \mathrm{~Hz}, 3 \mathrm{H}) ;{ }^{13} \mathrm{C} \mathrm{NMR}\left(126 \mathrm{MHz}, \mathrm{CDCl}_{3}\right) \delta 138.0$, $135.8,135.0,133.0,131.9,130.1,128.7,128.02,127.96,83.9,80.2,74.1,73.8,69.5$, 37.7, 36.5, 36.0, 27.0, 19.3, 15.9, 15.4, 13.9, 11.3; IR (thin film, $\mathrm{NaCl}$ ) 3451, 2959, $2858,1428,1112,1078,822,739,701,613 \mathrm{~cm}^{-1}$; LRMS (EI, Na) calcd for $\mathrm{C}_{36} \mathrm{H}_{50} \mathrm{O}_{4} \mathrm{Si}$, $597.87 \mathrm{~m} / z(\mathrm{M}+\mathrm{Na})$; observed, $597.50(\mathrm{M}+\mathrm{Na})^{+} \mathrm{m} / z$.

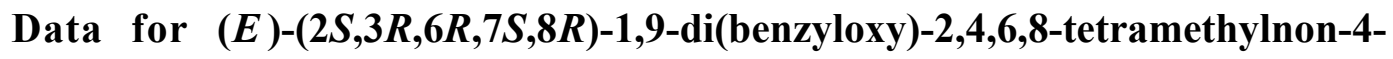
ene-3,7-diol, 53. $[\alpha]_{589}{ }^{20}+15.6^{\circ}\left(c 1.05, \mathrm{CHCl}_{3}\right) ;{ }^{1} \mathrm{H} \mathrm{NMR}\left(500 \mathrm{MHz}, \mathrm{CDCl}_{3}\right) \delta$ 7.68$7.66(\mathrm{~m}, 4 \mathrm{H}), 7.46-7.36(\mathrm{~m}, 6 \mathrm{H}), 7.36-7.28(\mathrm{~m}, 5 \mathrm{H}), 5.36(\mathrm{~d}, J=9.7 \mathrm{~Hz}, 1 \mathrm{H}), 4.53($ A of $\mathrm{AB}, J=12.0 \mathrm{~Hz}, 1 \mathrm{H}), 4.48(\mathrm{~B}$ of AB, $J=12.0 \mathrm{~Hz}, 1 \mathrm{H}), 4.17(\mathrm{~d}, J=3.9 \mathrm{~Hz}, 1 \mathrm{H}), 3.64$ (dd, $J=5.0,2.6 \mathrm{~Hz}, 1 \mathrm{H}), 3.61(\mathrm{dd}, J=9.0,4.1 \mathrm{~Hz}, 1 \mathrm{H}), 3.43(\mathrm{dd}, J=9.1,5.0 \mathrm{~Hz}, 1 \mathrm{H})$, $3.31(\mathrm{dd}, J=11.8,5.8 \mathrm{~Hz}, 1 \mathrm{H}), 3.01(\mathrm{~d}, J=6.0 \mathrm{~Hz}, 1 \mathrm{H}), 2.53-2.45(\mathrm{~m}, 2 \mathrm{H}), 1.93-1.81$ (m, 2H), 1.47 (d, $J=0.94 \mathrm{~Hz}, 3 \mathrm{H}), 1.07$ (s, 9H), $1.06(\mathrm{~d}, J=7.2 \mathrm{~Hz}, 3 \mathrm{H}), 0.98$ (d, $J=6.7$ $\mathrm{Hz}, 3 \mathrm{H}), 0.87(\mathrm{~d}, J=6.9 \mathrm{~Hz}, 3 \mathrm{H}) ;{ }^{13} \mathrm{C} \mathrm{NMR}\left(126 \mathrm{MHz}, \mathrm{CDCl}_{3}\right) \delta 138.1,135.9,135.8$, $134.7,133.6,133.5,129.96,129.93,128.9,128.7,128.00,127.96,127.93,127.92,80.2$, 78.1, 74.0, 73.8, 68.0, 38.0, 36.5, 35.9, 27.1, 19.3, 16.0, 15.5, 13.3, 10.9; IR (thin film, $\mathrm{NaCl}) 3440,2960,2930,2858,1454,1428,1112,1089,1006,823,739,701,614 \mathrm{~cm}^{-1}$; LRMS (EI, Na) calcd for $\mathrm{C}_{36} \mathrm{H}_{50} \mathrm{O}_{4} \mathrm{Si}, 597.87 \mathrm{~m} / z(\mathrm{M}+\mathrm{Na})$; observed, $597.50(\mathrm{M}+\mathrm{Na})^{+}$ $m / z$. 

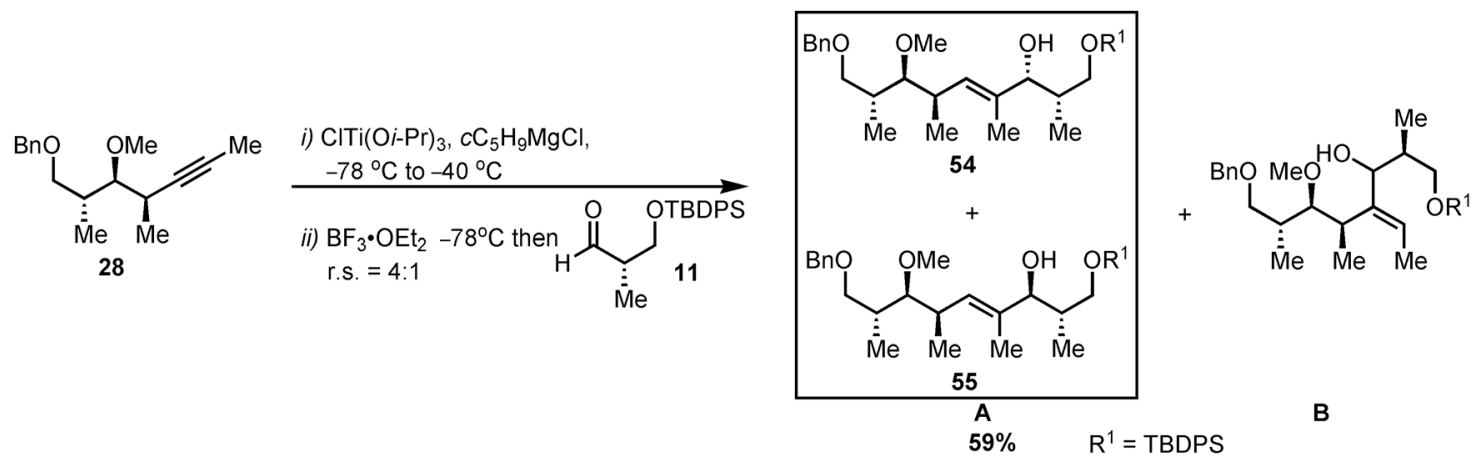

Entry 6 - synthesis of allylic alcohols 54 and 55. To a $-78{ }^{\circ} \mathrm{C}$ solution of alkyne $28(20 \mathrm{mg}, 0.075 \mathrm{mmol})$ in $0.75 \mathrm{~mL}$ of toluene, was added sequentially, $\mathrm{ClTi}(\mathrm{O} i \text {-Pr })_{3}(1.0$ $\mathrm{M}$ in hexanes; $170 \mu \mathrm{L}, 0.17 \mathrm{mmol})$ and $c-\mathrm{C}_{5} \mathrm{H}_{9} \mathrm{MgCl}(2.0 \mathrm{M}$ in diethyl ether; $170 \mu \mathrm{L}$, $0.34 \mathrm{mmol}$ ) in a dropwise manner via a dry gas-tight syringe. The resulting yellow solution was slowly warmed to $-40{ }^{\circ} \mathrm{C}$ and stirred for $2 \mathrm{~h}$ during which the reaction turned dark brown. The flask was then cooled to $-78{ }^{\circ} \mathrm{C}$ and $\mathrm{BF}_{3} \bullet \mathrm{OEt}_{2}(21 \mu \mathrm{L}, 0.17$ mmol) was added in a dropwise manner. Following a stirring period of $10 \mathrm{~min}$ at $-78{ }^{\circ} \mathrm{C}$, aldehyde 11 (78 mg, $0.24 \mathrm{mmol})$ was then added as a solution in toluene $(0.2 \mathrm{~mL})$ down the side of the flask via a gas tight syringe. The transfer was completed with additional toluene $(2 \times 0.1 \mathrm{~mL})$. Stirring was maintained for $1 \mathrm{~h}$ at $-78^{\circ} \mathrm{C}$, before the addition of saturated $\mathrm{NH}_{4} \mathrm{Cl}$ solution $(0.4 \mathrm{~mL})$. The suspension was allowed to reach ambient temperature before partitioning between EtOAc $(5 \mathrm{~mL})$ and water $(3 \mathrm{~mL})$. The phases were separated and the aqueous layer was extracted with EtOAc $(3 \times 5 \mathrm{~mL})$. The combined organic layer was then washed with sat. $\mathrm{NaHCO}_{3}$ solution $(2 \times 10 \mathrm{~mL})$, brine $(1 \times 10 \mathrm{~mL})$ and dried over anhydrous $\mathrm{Na}_{2} \mathrm{SO}_{4}$. The crude material was purified by flash column chromatography eluting successively with $2 \%(100 \mathrm{~mL}), 4 \%(100 \mathrm{~mL}), 7 \%$ $(100 \mathrm{~mL}), 10 \%(50 \mathrm{~mL}), 15 \%(100 \mathrm{~mL})$ and $20 \%(200 \mathrm{~mL})$ EtOAc/ hexanes to provide 
$26 \mathrm{mg}$ (59\%) of $\mathbf{5 4}$ and $\mathbf{5 5}$ as the major regioisomer A. Compound $\mathbf{5 4}$ was contaminated with an impurity. This contaminant was not included in the yield.

Entry 6 - Regioselectivity data A:B. The residue obtained after a titanium reductive coupling using the above procedure was filtered through a short pad of silica eluting successively with $2 \%(50 \mathrm{~mL})$ and $4 \%(50 \mathrm{~mL})$ EtOAc/ hexanes until all traces of the partially reduced product of alkyne $\mathbf{2 8}$ were removed. All remaining organics were removed by washing the silica with $200 \mathrm{~mL}$ of $100 \%$ EtOAc. Analysis of the partially purified mixture by ${ }^{1} \mathrm{H}$ NMR shows an approximately 4:1 mixture of regioisomers.

Entry 6 - Characterization data for 54. Due to contamination of allylic alcohol 54 with an unidentified impurity, characterization was performed on diol $\mathbf{5 6}$ obtained after a TBAF deprotection.

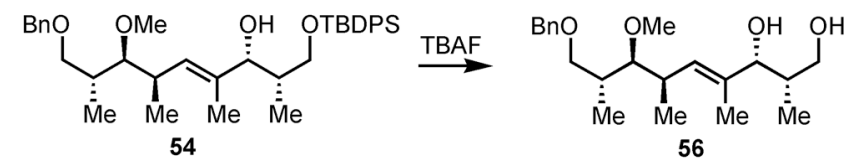

Data for diol 56. $[\alpha]_{589}{ }^{20}+12.5^{\circ}\left(c 0.36, \mathrm{CHCl}_{3}\right) ;{ }^{1} \mathrm{H}$ NMR $\left(500 \mathrm{MHz}, \mathrm{CDCl}_{3}\right) \delta$ 7.36-7.28 (m, 5H), 5.37 (d, $J=9.6 \mathrm{~Hz}, 1 \mathrm{H}), 4.51(\mathrm{~A}$ of AB, $J=12.1 \mathrm{~Hz}, 1 \mathrm{H}), 4.47$ (B of $\mathrm{AB}, J=12.1 \mathrm{~Hz}, 1 \mathrm{H}), 4.09(\mathrm{~d}, J=4.6 \mathrm{~Hz}, 1 \mathrm{H}), 3.66(\mathrm{~d}, J=5.1 \mathrm{~Hz}, 2 \mathrm{H}), 3.54(\mathrm{dd}, J=$ 8.9, $4.1 \mathrm{~Hz}, 1 \mathrm{H}), 3.44(\mathrm{~s}, 3 \mathrm{H}), 3.39(\mathrm{dd}, J=7.5,7.5 \mathrm{~Hz}, 1 \mathrm{H}), 2.94(\mathrm{dd}, J=2.9,2.9 \mathrm{~Hz}$, 1H), 2.69-2.62 (m, 1H), 2.00-1.94 (m, 1H), 1.94-1.86 (m, 1H), $1.81(\mathrm{~s} \mathrm{br}, 2 \mathrm{H}), 1.56(\mathrm{~s}$, $3 \mathrm{H}), 1.05(\mathrm{~d}, J=6.9 \mathrm{~Hz}, 3 \mathrm{H}), 0.98(\mathrm{~d}, J=6.7 \mathrm{~Hz}, 3 \mathrm{H}), 0.92(\mathrm{~d}, J=7.0 \mathrm{~Hz}, 3 \mathrm{H}) ;{ }^{13} \mathrm{C}$ NMR $\left(126 \mathrm{MHz}, \mathrm{CDCl}_{3}\right) \delta 139.0,135.2,129.4,128.5,127.9,127.7,88.1,79.1,73.3$, 72.3, 67.1, 61.6, 38.0, 37.1, 35.2, 16.1, 15.7, 13.4, 11.1; IR (thin film, $\mathrm{NaCl}$ ) 3395, 2965, 2925, 2875, 1454, 1453, 1110, 1086, 1028, 734, $695 \mathrm{~cm}^{-1}$; LRMS (EI, Na) calcd for $\mathrm{C}_{21} \mathrm{H}_{34} \mathrm{O}_{4}, 373.49 \mathrm{~m} / \mathrm{z}(\mathrm{M}+\mathrm{Na})$; observed, $373.40(\mathrm{M}+\mathrm{Na})^{+} \mathrm{m} / \mathrm{z}$. 


\section{Data for minor diastereomer $(E)-(2 S, 3 S, 6 R, 7 S, 8 S)-11-(t e r t-$}

butyldiphenylsilanyloxy)-7-(methoxy)- 9-(benzyloxy)--2,4,6,8-tetramethylnon-4-ene-

3-ol, 55. $[\alpha]_{589}{ }^{20}+14.8^{\circ}\left(c\right.$ 1.01, $\left.\mathrm{CHCl}_{3}\right) ;{ }^{1} \mathrm{H} \mathrm{NMR}\left(500 \mathrm{MHz}, \mathrm{CDCl}_{3}\right) \delta$ 7.71-7.69 (m, 4H), 7.48-7.40 (m, 6H), 7.34-7.31 (m, 5H), 5.34 (d, $J=9.9 \mathrm{~Hz}, 1 \mathrm{H}), 4.49$ (A of AB, $J=$ 12.1 Hz, 1 H), $4.48(\mathrm{~B}$ of $\mathrm{AB}, J=12.1 \mathrm{~Hz}, 1 \mathrm{H}), 3.93(\mathrm{~s}, 1 \mathrm{H}), 3.90(\mathrm{~d}, J=8.6 \mathrm{~Hz}, 1 \mathrm{H})$, $3.79(\mathrm{dd}, J=4.0,10.1 \mathrm{~Hz}, 1 \mathrm{H}), 3.65(\mathrm{dd}, J=7.9,10.0 \mathrm{~Hz}, 1 \mathrm{H}), 3.53(\mathrm{dd}, J=8.9,4.1 \mathrm{~Hz}$, $1 \mathrm{H}), 3.41(\mathrm{~s}, 3 \mathrm{H}), 3.38-3.35(\mathrm{~m}, 1 \mathrm{H}), 2.90(\mathrm{dd}, J=5.9,5.9 \mathrm{~Hz}, 1 \mathrm{H}), 2.68-2.60(\mathrm{~m}, 1 \mathrm{H})$, 1.99-1.90 (m, 2H), $1.60(\mathrm{~d}, J=1.1 \mathrm{~Hz}, 3 \mathrm{H}), 1.08(\mathrm{~s}, 9 \mathrm{H}), 1.04(\mathrm{~d}, J=6.9 \mathrm{~Hz}, 3 \mathrm{H}), 1.00$ $(\mathrm{d}, J=6.7 \mathrm{~Hz}, 3 \mathrm{H}), 0.66(\mathrm{~d}, J=6.9 \mathrm{~Hz}, 3 \mathrm{H}) ;{ }^{13} \mathrm{C} \mathrm{NMR}\left(126 \mathrm{MHz}, \mathrm{CDCl}_{3}\right) \delta 139.0$, $135.84,135.83,135.0,133.0,132.4,130.1,128.5,128.0,127.8,127.6,88.2,84.1,73.2$, $72.3,69.6,61.5,37.8,37.1,35.2,27.1,19.3,16.0,15.6,13.8,11.2 ;$ IR (thin film, $\mathrm{NaCl}$ ) 3481, 2961, 2930, 2856, 1472, 1456, 1428, 1089, 1006, 739, $701 \mathrm{~cm}^{-1}$; LRMS (EI, Na) calcd for $\mathrm{C}_{37} \mathrm{H}_{52} \mathrm{O}_{4} \mathrm{Si}, 611.89 \mathrm{~m} / z(\mathrm{M}+\mathrm{Na})$; observed, $611.47(\mathrm{M}+\mathrm{Na})^{+} \mathrm{m} / z$.
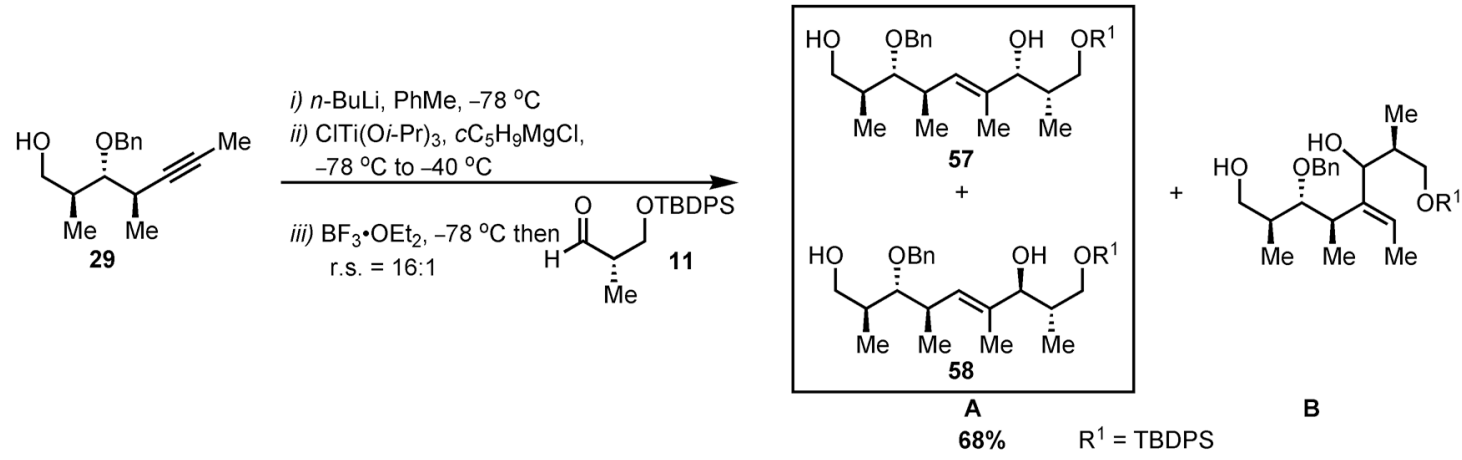

Entry 7 - synt hesis of ene-diol 57 and 58. To a $-78{ }^{\circ} \mathrm{C}$ solution of alkyne 29 (20 mg, $0.081 \mathrm{mmol})$ in $0.81 \mathrm{~mL}$ of toluene, was added sequentially, $n$-BuLi $(2.27 \mathrm{M}$ in hexanes; $39 \mu \mathrm{L}, 0.089 \mathrm{mmol}), \operatorname{ClTi}(\mathrm{O} i-\mathrm{Pr})_{3}(1.0 \mathrm{M}$ in hexanes; $180 \mu \mathrm{L}, 0.18 \mathrm{mmol})$ and $c-\mathrm{C}_{5} \mathrm{H}_{9} \mathrm{MgCl}(2.0 \mathrm{M}$ in diethyl ether; $180 \mu \mathrm{L}, 0.36 \mathrm{mmol})$ in a dropwise manner via a dry gas-tight syringe. The resulting yellow solution was slowly warmed to $-40{ }^{\circ} \mathrm{C}$ and stirred 
for $2 \mathrm{~h}$ during which the reaction turned dark brown. The flask was then cooled to $-78{ }^{\circ} \mathrm{C}$ and $\mathrm{BF}_{3} \bullet \mathrm{OEt}_{2}(33 \mu \mathrm{L}, 0.26 \mathrm{mmol})$ was added in a dropwise manner. Following a stirring period of $10 \mathrm{~min}$ at $-78{ }^{\circ} \mathrm{C}$, aldehyde $11(85 \mathrm{mg}, 0.26 \mathrm{mmol})$ was then added as a solution in toluene $(0.2 \mathrm{~mL})$ down the side of the flask via a gas tight syringe. The transfer was completed with additional toluene $(2 \times 0.1 \mathrm{~mL})$. Stirring was maintained for $1 \mathrm{~h}$ at $-78{ }^{\circ} \mathrm{C}$, before the addition of saturated $\mathrm{NH}_{4} \mathrm{Cl}$ solution $(0.4 \mathrm{~mL})$. The suspension was allowed to reach ambient temperature before partitioning between EtOAc $(5 \mathrm{~mL})$ and water $(3 \mathrm{~mL})$. The phases were separated and the aqueous layer was extracted with EtOAc $(3 \times 5 \mathrm{~mL})$. The combined organic layer was then washed with sat. $\mathrm{NaHCO}_{3}$ solution $(2 \times 10 \mathrm{~mL})$, brine $(1 \times 10 \mathrm{~mL})$ and dried over anhydrous $\mathrm{Na}_{2} \mathrm{SO}_{4}$. The crude material was purified by flash column chromatography eluting successively with $5 \%$ $(100 \mathrm{~mL}), 7 \%(50 \mathrm{~mL}), 10 \%(100 \mathrm{~mL}), 15 \%(50 \mathrm{~mL}), 20 \%(100 \mathrm{~mL})$ and $30 \%(200$ $\mathrm{mL}$ ) EtOAc/ hexanes to provide $32 \mathrm{mg}(68 \%)$ of diastereomers 57 and $\mathbf{5 8}$ as the major regioisomer $\mathbf{A}$.

Entry 7 - Regioselectivity data A:B. The residue obtained after a titanium reductive coupling using the above procedure was filtered through a short pad of silica eluting successively with $5 \%(100 \mathrm{~mL}), 7 \%(50 \mathrm{~mL}), 10 \%(50 \mathrm{~mL})$ and $15 \%(50 \mathrm{~mL})$ EtOAc/ hexanes until all traces of the partially reduced olefinic product alkyne $\mathbf{2 9}$ were removed. All remaining organics were removed by washing the silica with $200 \mathrm{~mL}$ of $100 \%$ EtOAc. Analysis of the partially purified mixture by ${ }^{1} \mathrm{H}$ NMR shows an approximately 16:1 mixture of regioisomers. 


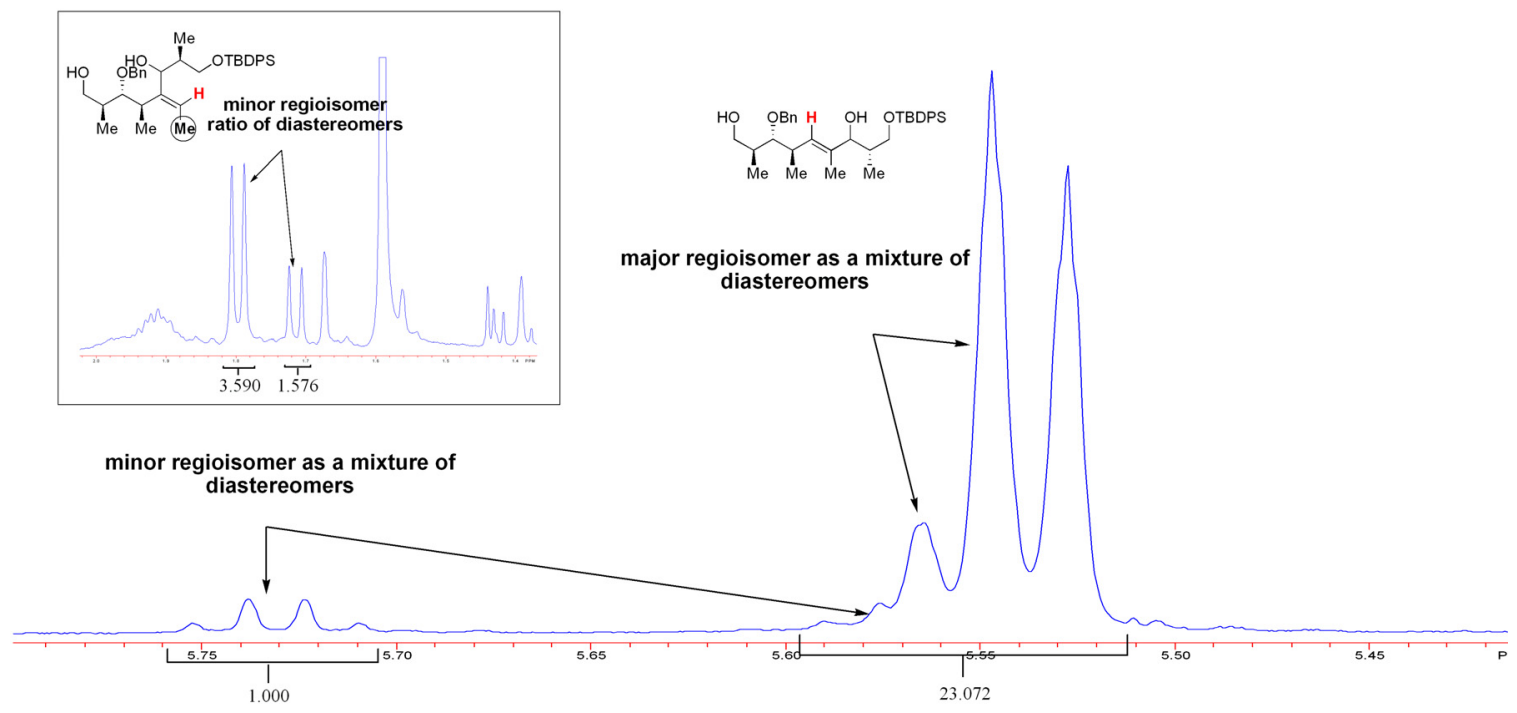

Data for major diastereomer (E)-(2S,3R,6R,7R,8S)-1-(tertbutyldimethylsilanyloxy)-7-(benzyloxy)-2,4,6,8-tetramethylnon-4-ene-3,9-diol, 57. $[\alpha]_{589}{ }^{20}-8.1^{\circ}\left(c\right.$ 3.3, $\left.\mathrm{CHCl}_{3}\right) ;{ }^{1} \mathrm{H} \mathrm{NMR}\left(500 \mathrm{MHz}, \mathrm{CDCl}_{3}\right) \delta$ 7.69-7.67 (m, 4H), 7.44-7.28 $(\mathrm{m}, 11 \mathrm{H}), 5.54(\mathrm{~d}, J=9.7 \mathrm{~Hz}, 1 \mathrm{H}), 4.72(\mathrm{~A}$ of $\mathrm{AB}, J=11.1 \mathrm{~Hz}, 1 \mathrm{H}), 4.61(\mathrm{~B}$ of $\mathrm{AB}, J=$ $11.1 \mathrm{~Hz}, 1 \mathrm{H}), 4.80(\mathrm{~d}, J=4.4 \mathrm{~Hz}, 1 \mathrm{H}), 3.71(\mathrm{dd}, J=10.9,3.6 \mathrm{~Hz}, 1 \mathrm{H}), 3.66-3.61(\mathrm{~m}$, 3H), $3.31(\mathrm{dd}, J=7.1,4.1 \mathrm{~Hz}, 1 \mathrm{H}), 2.83-2.76(\mathrm{~m}, 1 \mathrm{H}), 2.47$ (s br, 1H), 1.91-1.84 (m, 2H), $1.57(\mathrm{~s}, 3 \mathrm{H}), 1.08(\mathrm{~s}, 9 \mathrm{H}), 1.04(\mathrm{~d}, J=6.9 \mathrm{~Hz}, 3 \mathrm{H}), 0.96(\mathrm{~d}, J=7.0 \mathrm{~Hz}, 3 \mathrm{H}), 0.92(\mathrm{~d}, J=$ $6.9 \mathrm{~Hz}, 3 \mathrm{H}) ;{ }^{13} \mathrm{C} \mathrm{NMR}\left(126 \mathrm{MHz}, \mathrm{CDCl}_{3}\right) \delta$ 138.5, 135.98, 135.88, 135.80, 133.6, 133.5, $129.92,129.89,128.6,127.93,127.90,127.34,89.1,78.3,75.4,68.0,66.5,38.2,38.1$, $35.7,27.1,19.4,18.3,15.5,13.3,11.1$; IR (thin film, $\mathrm{NaCl}$ ) 3422, 2961, 2930, 2859, 1473, 1456, 1362, 1112, 999, 824, 739, 701, $614 \mathrm{~cm}^{-1}$; LRMS (EI, Na) calcd for $\mathrm{C}_{36} \mathrm{H}_{50} \mathrm{O}_{4} \mathrm{Si}, 597.87 \mathrm{~m} / z(\mathrm{M}+\mathrm{Na})$; observed, $597.51(\mathrm{M}+\mathrm{Na})^{+} \mathrm{m} / z$.

Data for minor diastereomer $(E)-(2 S, 3 S, 6 R, 7 R, 8 S)-1-($ tertbutyldimethylsilanyloxy)-7-(benzyloxy)-2,4,6,8-tetramethylnon-4-ene-3,9-diol, 58. 
$[\alpha]_{589}{ }^{20}-24.5^{\circ}\left(c \quad 0.69, \mathrm{CHCl}_{3}\right) ;{ }^{1} \mathrm{H}$ NMR $\left(500 \mathrm{MHz}, \mathrm{CDCl}_{3}\right) \delta$ 7.70-7.68 (m, 4H), 7.42$7.30(\mathrm{~m}, 11 \mathrm{H}), 5.55(\mathrm{~d}, J=9.3 \mathrm{~Hz}, 1 \mathrm{H}), 4.73(\mathrm{~A}$ of $\mathrm{AB}, J=11.0 \mathrm{~Hz}, 1 \mathrm{H}), 4.61(\mathrm{~B}$ of AB, $J=11.0 \mathrm{~Hz}, 1 \mathrm{H}), 3.96(\mathrm{~d}, J=8.7 \mathrm{~Hz}, 1 \mathrm{H}), 3.78(\mathrm{dd}, J=10.1,4.1 \mathrm{~Hz}, 1 \mathrm{H}), 3.68-$ $3.61(\mathrm{~m}, 3 \mathrm{H}), 3.31(\mathrm{dd}, J=7.9,3.5 \mathrm{~Hz}, 1 \mathrm{H}), 2.84-2.77(\mathrm{~m}, 1 \mathrm{H}), 2.00-1.92(\mathrm{~m}, 1 \mathrm{H}), 1.83-$ $1.78(\mathrm{~m}, 1 \mathrm{H}), 1.68(\mathrm{~d}, J=1.1 \mathrm{~Hz}, 3 \mathrm{H}), 1.15(\mathrm{~d}, J=7.0 \mathrm{~Hz}, 3 \mathrm{H}), 1.07$ (s, 9H), $0.91(\mathrm{~d}, J=$ $7.0 \mathrm{~Hz}, 3 \mathrm{H}), 0.63(\mathrm{~d}, J=6.9 \mathrm{~Hz}, 3 \mathrm{H}) ;{ }^{13} \mathrm{C}$ NMR $\left(126 \mathrm{MHz}, \mathrm{CDCl}_{3}\right) \delta 138.5,136.2$, $135.8,132.94,132.92,130.0,128.7,128.04,128.02,127.98,127.95,88.7,84.4,75.5$, 70.0, 66.8, 38.7, 37.6, 35.7, 27.1, 19.3, 18.5, 15.2, 13.8, 11.2; IR (thin film, $\mathrm{NaCl}$ ) 3440, 2960, 2929, 2858, 1471, 1454, 1428, 1112, 1028, 1006, 823, 738, 701, $614 \mathrm{~cm}^{-1}$; LRMS (EI, Na) calcd for $\mathrm{C}_{36} \mathrm{H}_{50} \mathrm{O}_{4} \mathrm{Si}, 597.87 \mathrm{~m} / z(\mathrm{M}+\mathrm{Na})$; observed, $597.00(\mathrm{M}+\mathrm{Na})^{+}$ $m / z$.observed, $(\mathrm{M}+\mathrm{Na})^{+} m / z$.
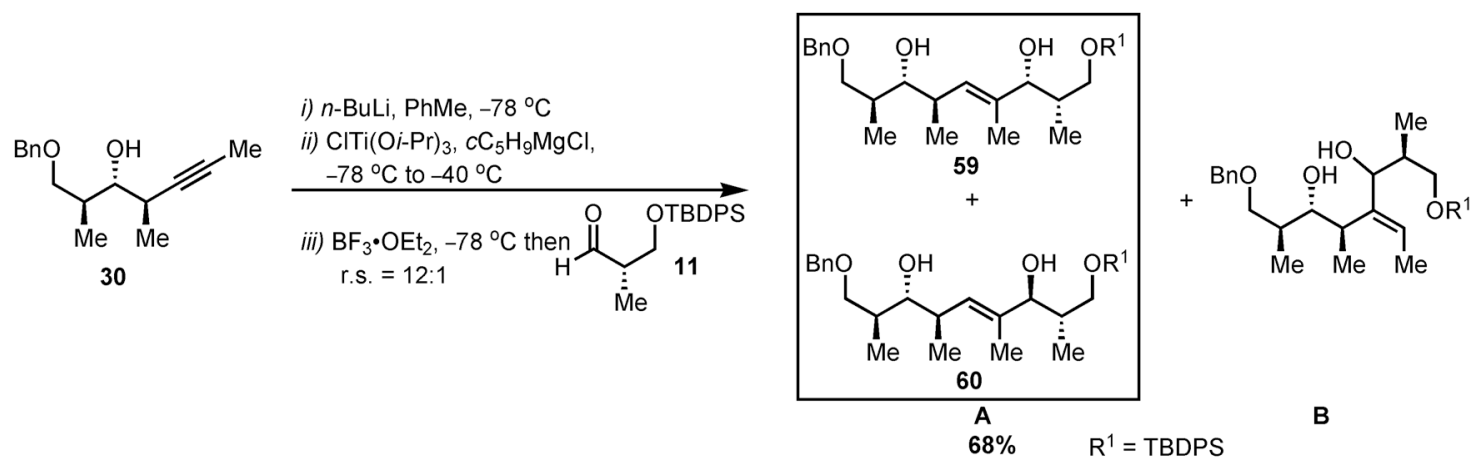

Entry 8 - synthesis of ene-1,5-diol 59 and 60 . To a $-78{ }^{\circ} \mathrm{C}$ solution of alkyne 30 (20 mg, $0.081 \mathrm{mmol})$ in $0.81 \mathrm{~mL}$ of toluene, was added sequentially, $n$-BuLi (2.27 M in hexanes; $39 \mu \mathrm{L}, 0.089 \mathrm{mmol}), \mathrm{ClTi}(\mathrm{O} i-\mathrm{Pr})_{3}(1.0 \mathrm{M}$ in hexanes; $180 \mu \mathrm{L}, 0.18 \mathrm{mmol})$ and $c-\mathrm{C}_{5} \mathrm{H}_{9} \mathrm{MgCl}(2.0 \mathrm{M}$ in diethyl ether; $180 \mu \mathrm{L}, 0.36 \mathrm{mmol})$ in a dropwise manner via a dry gas-tight syringe. The resulting yellow solution was slowly warmed to $-40{ }^{\circ} \mathrm{C}$ and stirred for $2 \mathrm{~h}$ during which the reaction turned dark brown. The flask was then cooled to $-78{ }^{\circ} \mathrm{C}$ and $\mathrm{BF}_{3} \bullet \mathrm{OEt}_{2}(33 \mu \mathrm{L}, 0.26 \mathrm{mmol})$ was added in a dropwise manner. Following a stirring 
period of $10 \mathrm{~min}$ at $-78{ }^{\circ} \mathrm{C}$, aldehyde $\mathbf{1 1}(85 \mathrm{mg}, 0.26 \mathrm{mmol})$ was then added as a solution in toluene $(0.2 \mathrm{~mL})$ down the side of the flask via a gas tight syringe. The transfer was completed with additional toluene $(2 \times 0.1 \mathrm{~mL})$. Stirring was maintained for $1 \mathrm{~h}$ at $-78{ }^{\circ} \mathrm{C}$, before the addition of saturated $\mathrm{NH}_{4} \mathrm{Cl}$ solution $(0.4 \mathrm{~mL})$. The suspension was allowed to reach ambient temperature before partitioning between EtOAc $(5 \mathrm{~mL})$ and water $(3 \mathrm{~mL})$. The phases were separated and the aqueous layer was extracted with EtOAc $(3 \times 5 \mathrm{~mL})$. The combined organic layer was then washed with sat. $\mathrm{NaHCO}_{3}$ solution $(2 \times 10 \mathrm{~mL})$, brine $(1 \times 10 \mathrm{~mL})$ and dried over anhydrous $\mathrm{Na}_{2} \mathrm{SO}_{4}$. The crude material was purified by flash column chromatography eluting successively with $2 \%$ $(100 \mathrm{~mL}), 4 \%(100 \mathrm{~mL}), 7 \%(50 \mathrm{~mL}), 10 \%(50 \mathrm{~mL}), 15 \%(100 \mathrm{~mL})$ and $20 \%(200$ $\mathrm{mL}$ ) EtOAc/ hexanes to provide $32 \mathrm{mg}(68 \%)$ of diastereomers 59 and $\mathbf{6 0}$ as the major regioisomer $\mathbf{A}$.

Entry 8 - Regioselectivity data A:B. The residue obtained after a titanium reductive coupling using the above procedure was filtered through a short pad of silica eluting successively with $2 \%(100 \mathrm{~mL}), 4 \%(50 \mathrm{~mL})$ and $6 \%(50 \mathrm{~mL})$ EtOAc/ hexanes until all traces of the partially reduced olefinic product alkyne $\mathbf{3 0}$ were removed. All remaining organics were removed by washing the silica with $200 \mathrm{~mL}$ of $100 \%$ EtOAc. Analysis of the partially purified mixture by ${ }^{1} \mathrm{H}$ NMR shows an approximately 12:1 mixture of regioisomers.

\section{Data for major diastereomer $(E)-(2 R, 3 S, 6 R, 7 R, 8 S)-1-(t e r t-$} butyldiphenylsilanyloxy)- 9-(benzyloxy)-2,4,6,8-tetramethylnon-4-ene-3,7-diol, 59. $[\alpha]_{589}{ }^{20}+13.8^{\circ}\left(c\right.$ 2.9, $\left.\mathrm{CHCl}_{3}\right) ;{ }^{1} \mathrm{H}$ NMR $\left(500 \mathrm{MHz}, \mathrm{CDCl}_{3}\right) \delta$ 7.69-7.68 (m, 4H), 7.45$7.28(\mathrm{~m}, 11 \mathrm{H}), 5.57$ (d, $J=9.8 \mathrm{~Hz}, 1 \mathrm{H}), 4.55-4.50(\mathrm{~m}, 2 \mathrm{H}), 4.21(\mathrm{~d}, J=4.0 \mathrm{~Hz}, 1 \mathrm{H})$, 
3.68-3.63 (m, 2H), $3.58(\mathrm{dd}, J=9.2,4.5 \mathrm{~Hz}, 1 \mathrm{H}), 3.54-3.51(\mathrm{~m}, 1 \mathrm{H}), 3.40(\mathrm{dd}, J=7.5$, $4.1 \mathrm{~Hz}, 1 \mathrm{H}), 2.63-2.57(\mathrm{~m}, 1 \mathrm{H}), 1.93-1.86(\mathrm{~m}, 2 \mathrm{H}), 1.56(\mathrm{~s}, 3 \mathrm{H}), 1.08(\mathrm{~s}, 9 \mathrm{H}), 0.99(\mathrm{~d}, J=$ $6.9 \mathrm{~Hz}, 3 \mathrm{H}), 0.92(\mathrm{~d}, J=6.9 \mathrm{~Hz}, 3 \mathrm{H}), 0.86(\mathrm{~d}, J=7.0 \mathrm{~Hz}, 3 \mathrm{H}) ;{ }^{13} \mathrm{C}$ NMR $(126 \mathrm{MHz}$, $\left.\mathrm{CDCl}_{3}\right) \delta 138.0,136.1,135.9,135.8,133.6,133.5,129.91,129.89,128.7,127.94,127.90$, $127.89,126.4,80.3,78.1,75.5,73.7,68.0,38.1,36.6,35.5,27.1,19.4,18.0,14.4,13.5$, 10.9; IR (thin film, $\mathrm{NaCl}$ ) 3447, 2960, 2930, 2858, 1454, 1427, 1112, 1028, 824, 739, 701, $614 \mathrm{~cm}^{-1}$; LRMS (EI, Na) calcd for $\mathrm{C}_{36} \mathrm{H}_{50} \mathrm{O}_{4} \mathrm{Si}, 597.87 \mathrm{~m} / z(\mathrm{M}+\mathrm{Na})$; observed, $597.52(\mathrm{M}+\mathrm{Na})^{+} \mathrm{m} / z$.

Data for minor diastereomer $(E)-(2 R, 3 R, 6 R, 7 R, 8 S)-1-(t e r t-$ butyldiphenylsilanyloxy)- 9-(benzyloxy)-2,4,6,8-tetramethylnon-4-ene-3,7-diol, 60. $[\alpha]_{589}{ }^{20}+19.6^{\circ}\left(c 1.31, \mathrm{CHCl}_{3}\right) ;{ }^{1} \mathrm{H} \mathrm{NMR}\left(500 \mathrm{MHz}, \mathrm{CDCl}_{3}\right) \delta$ 7.71-7.70 (m, 4H), 7.48$7.40(\mathrm{~m}, 6 \mathrm{H}), 7.36-7.28(\mathrm{~m}, 5 \mathrm{H}), 5.54(\mathrm{~d}, J=9.7 \mathrm{~Hz}, 1 \mathrm{H}), 4.52(\mathrm{~A}$ of $\mathrm{AB}, J=12.1 \mathrm{~Hz}$, 1H), 4.51 ( B of AB, $J=12.1 \mathrm{~Hz}, 1 \mathrm{H}), 3.97(\mathrm{~d}, J=8.9 \mathrm{~Hz}, 1 \mathrm{H}), 3.79$ (dd, $J=10.2,4.2$ Hz, 1H), $3.67(\mathrm{dd}, J=9.9,8.3 \mathrm{~Hz}, 1 \mathrm{H}), 3.57(\mathrm{dd}, J=9.2,4.2 \mathrm{~Hz}, 1 \mathrm{H}), 3.50(\mathrm{dd}, J=8.2$, $8.2 \mathrm{~Hz}, 1 \mathrm{H}), 3.41(\mathrm{dd}, J=8.0,3.7 \mathrm{~Hz}, 1 \mathrm{H}), 2.64-2.58(\mathrm{~m}, 1 \mathrm{H}), 2.01-1.92(\mathrm{~m}, 1 \mathrm{H}), 1.88-$ $1.79(\mathrm{~m}, 1 \mathrm{H}), 1.67(\mathrm{~d}, J=0.8 \mathrm{~Hz}, 3 \mathrm{H}), 1.09-1.07(\mathrm{~m}, 12 \mathrm{H}), 0.82(\mathrm{~d}, J=7.0 \mathrm{~Hz}, 3 \mathrm{H}), 0.65$ $(\mathrm{d}, J=6.9 \mathrm{~Hz}, 3 \mathrm{H}) ;{ }^{13} \mathrm{C} \mathrm{NMR}\left(126 \mathrm{MHz}, \mathrm{CDCl}_{3}\right) \delta 137.9,136.1,135.8,133.0,130.1$, $129.6,129.7,128.03,128.01,127.99,127.92,84.3,80.4,75.9,73.7,69.8,37.6,36.7$, 35.5, 27.0, 19.4, 18.0, 14.1, 13.8, 11.1; IR (thin film, $\mathrm{NaCl}$ ) 3469, 2960, 2929, 2858, 1454, 1428, 1113, 1087, 1005, 823, 739, 701, $615 \mathrm{~cm}^{-1}$; LRMS (EI, Na) calcd for $\mathrm{C}_{36} \mathrm{H}_{50} \mathrm{O}_{4} \mathrm{Si}, 597.87 \mathrm{~m} / z(\mathrm{M}+\mathrm{Na})$; observed, $597.52(\mathrm{M}+\mathrm{Na})^{+} \mathrm{m} / z$. 

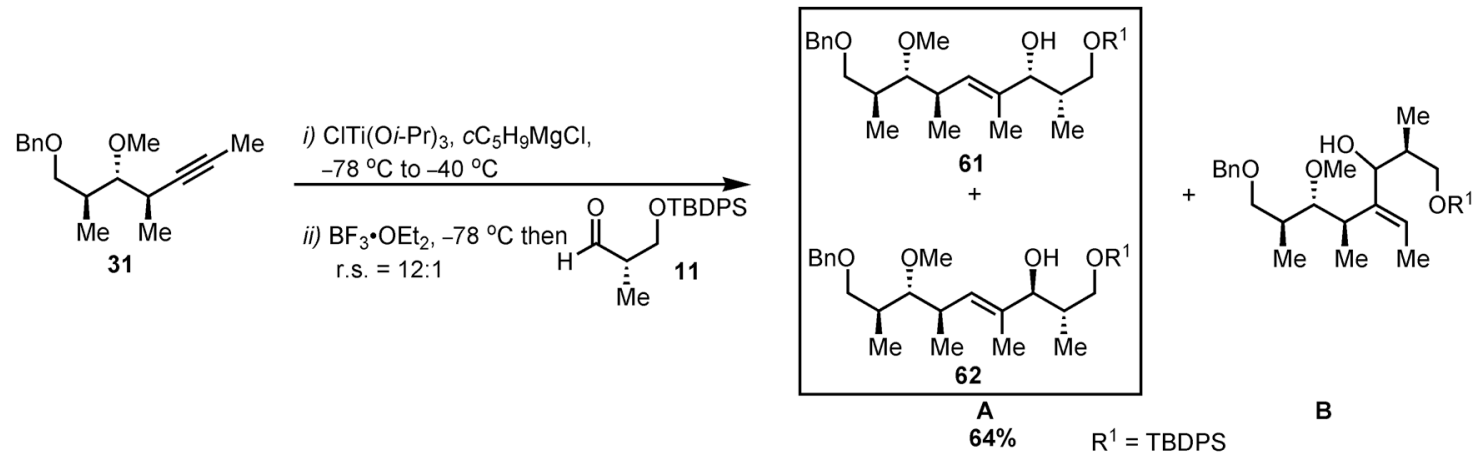

Entry 9 - synthesis of enol 61 and 62. To a $-78{ }^{\circ} \mathrm{C}$ solution of alkyne 31 (20 $\mathrm{mg}$, $0.075 \mathrm{mmol})$ in $0.75 \mathrm{~mL}$ of toluene, was added sequentially, ClTi(Oi-Pr) $)_{3}(1.0 \mathrm{M}$ in hexanes; $170 \mu \mathrm{L}, 0.17 \mathrm{mmol})$ and $c-\mathrm{C}_{5} \mathrm{H}_{9} \mathrm{MgCl}(2.0 \mathrm{M}$ in diethyl ether; $170 \mu \mathrm{L}, 0.34$ mmol) in a dropwise manner via a dry gas-tight syringe. The resulting yellow solution was slowly warmed to $-40{ }^{\circ} \mathrm{C}$ and stirred for $2 \mathrm{~h}$ during which the reaction turned dark brown. The flask was then cooled to $-78^{\circ} \mathrm{C}$ and $\mathrm{BF}_{3} \bullet \mathrm{OEt}_{2}(21 \mu \mathrm{L}, 0.17 \mathrm{mmol})$ was added in a dropwise manner. Following a stirring period of $10 \mathrm{~min}$ at $-78^{\circ} \mathrm{C}$, aldehyde $11(78 \mathrm{mg}, 0.24 \mathrm{mmol})$ was then added as a solution in toluene $(0.2 \mathrm{~mL})$ down the side of the flask via a gas tight syringe. The transfer was completed with additional toluene $(2 \times$ $0.1 \mathrm{~mL}$ ). Stirring was maintained for $1 \mathrm{~h}$ at $-78{ }^{\circ} \mathrm{C}$, before the addition of saturated $\mathrm{NH}_{4} \mathrm{Cl}$ solution $(0.4 \mathrm{~mL})$. The suspension was allowed to reach ambient temperature before partitioning between EtOAc $(5 \mathrm{~mL})$ and water $(3 \mathrm{~mL})$. The phases were separated and the aqueous layer was extracted with EtOAc $(3 \times 5 \mathrm{~mL})$. The combined organic layer was then washed with sat. $\mathrm{NaHCO}_{3}$ solution $(2 \times 10 \mathrm{~mL})$, brine $(1 \times 10 \mathrm{~mL})$ and dried over anhydrous $\mathrm{Na}_{2} \mathrm{SO}_{4}$. The crude material was purified by flash column chromatography eluting successively with $2 \%(100 \mathrm{~mL}), 4 \%(100 \mathrm{~mL}), 7 \%(100 \mathrm{~mL})$, $10 \%(50 \mathrm{~mL}), 15 \%(100 \mathrm{~mL})$ and $20 \%(200 \mathrm{~mL})$ EtOAc/ hexanes to provide $29 \mathrm{mg}(64$ $\%)$ of 61 and 62 as the major regioisomer $\mathbf{A}$. 
Entry 9 - Regioselectivity data A:B. The residue obtained after a titanium reductive coupling using the above procedure was filtered through a short pad of silica eluting successively with $2 \%(50 \mathrm{~mL})$ and $4 \%(50 \mathrm{~mL})$ EtOAc/ hexanes until all traces of the partially reduce olefinic product alkyne $\mathbf{3 1}$ were removed. All remaining organics were removed by washing the silica with $200 \mathrm{~mL}$ of $100 \%$ EtOAc. Analysis of the partially purified mixture by ${ }^{1} \mathrm{H}$ NMR shows an approximately 10:1 mixture of regioisomers.

Data for major diastereomer $(E)-(2 S, 3 R, 6 R, 7 S, 8 S)-1-(t e r t-$ butyldiphenylsilanyloxy)-7-(methoxy)- 9-(benzyloxy)- 2,4,6,8-tetramethylnon-4-ene3-ol, 61. $\left.[\alpha]_{589}{ }^{20}+1.08^{\circ}(c) 3.2, \mathrm{CHCl}_{3}\right) ;{ }^{1} \mathrm{H} \mathrm{NMR}\left(500 \mathrm{MHz}, \mathrm{CDCl}_{3}\right) \delta$ 7.71-7.68 (m, 4H), 7.46-7.35 (m, 10H), 7.31-7.28 (m, 1H), 5.51 (d, $J=9.8 \mathrm{~Hz}, 1 \mathrm{H}), 4.54-4.49(\mathrm{~m}, 2 \mathrm{H})$, $4.18(\mathrm{~d}, J=4.2 \mathrm{~Hz}, 1 \mathrm{H}), 3.65-3.64(\mathrm{~m}, 2 \mathrm{H}), 3.52-3.51(\mathrm{~m}, 2 \mathrm{H}), 3.43(\mathrm{~s}, 3 \mathrm{H}), 3.00(\mathrm{dd}, J=$ 8.2, 3.4 Hz, 1H), 2.68-2.62 (m, 1H), 2.44-2.18 (s br, 1H), 1.90-1.80 (m, 2H), $1.54(\mathrm{~s}, 3 \mathrm{H})$, $1.08(\mathrm{~s}, 9 \mathrm{H}), 0.99(\mathrm{~d}, J=6.9 \mathrm{~Hz}, 3 \mathrm{H}), 0.95(\mathrm{~d}, J=6.9 \mathrm{~Hz}, 3 \mathrm{H}), 0.92(\mathrm{~d}, J=6.9 \mathrm{~Hz}, 3 \mathrm{H})$; ${ }^{13} \mathrm{C}$ NMR $\left(126 \mathrm{MHz}, \mathrm{CDCl}_{3}\right) \delta 139.0,135.9,135.81,135.77,135.3,129.90,129.88$, $128.5,128.1,127.95,127.90,127.76,127.61,126.9,87.5,78.3,73.2,72.8,68.1,61.4$, 38.1, 37.7, 35.0, 27.1, 19.4, 18.6, 15.1, 13.3, 11.0; IR (thin film, NaCl) 3465, 2961, 2930, 2858, 1471, 1428, 1362, 1112, 1008, 824, 739, 701, $614 \mathrm{~cm}^{-1}$; LRMS (EI, Na) calcd for $\mathrm{C}_{37} \mathrm{H}_{52} \mathrm{O}_{4} \mathrm{Si}, 611.89 \mathrm{~m} / z(\mathrm{M}+\mathrm{Na})$; observed, $611.48(\mathrm{M}+\mathrm{Na})^{+} \mathrm{m} / z$.

Data for minor diastereomer $(E)-(2 S, 3 S, 6 R, 7 S, 8 S)-11-($ tertbutyldiphenylsilanyloxy)-7-(methoxy)- 9-(benzyloxy)--2,4,6,8-tetramethylnon-4-ene3-ol, 62. $[\alpha]_{589}{ }^{20}+5.6^{\circ}\left(c 1.4, \mathrm{CHCl}_{3}\right)$; ${ }^{1} \mathrm{H} \mathrm{NMR}\left(500 \mathrm{MHz}, \mathrm{CDCl}_{3}\right) \delta$ 7.71-7.69 (m, 4H), 7.45-7.40 (m, 6H), 7.36-7.33 (m, 5H), $5.46(\mathrm{~d}, J=9.8 \mathrm{~Hz}, 1 \mathrm{H}), 4.51(\mathrm{~A}$ of $\mathrm{AB}, J=12.2$ 
$\mathrm{Hz}, 1 \mathrm{H})$, ), 4.49 (B of AB, $J=12.2 \mathrm{~Hz}, 1 \mathrm{H}), 3.95$ (d, $J=9.0 \mathrm{~Hz}, 1 \mathrm{H}), 3.77$ (dd, $J=10.1$, $4.2 \mathrm{~Hz}, 1 \mathrm{H}), 3.65$ (dd, $J=9.9,7.8 \mathrm{~Hz}, 1 \mathrm{H}), 3.52(\mathrm{dd}, J=8.9,5.6 \mathrm{~Hz}, 1 \mathrm{H}), 3.48$ (dd, $J=$ 8.8, 3.6 Hz, 1H), $3.44(\mathrm{~s}, 3 \mathrm{H}), 3.02(\mathrm{dd}, J=6.8,3.7 \mathrm{~Hz}, 1 \mathrm{H}), 2.71-2.64(\mathrm{~m}, 1 \mathrm{H}), 2.00-$ $1.93(\mathrm{~m}, 1 \mathrm{H}), 1.77-1.71(\mathrm{~m}, 1 \mathrm{H}), 1.65(\mathrm{~d}, J=0.7 \mathrm{~Hz}, 3 \mathrm{H}), 1.09$ (d, $J=7.0 \mathrm{~Hz}, 3 \mathrm{H}), 1.07$ (s, 9H), $0.93(\mathrm{~d}, J=6.9 \mathrm{~Hz}, 3 \mathrm{H}), 0.62(\mathrm{~d}, J=6.9 \mathrm{~Hz}, 3 \mathrm{H}) ;{ }^{13} \mathrm{C} \mathrm{NMR}\left(126 \mathrm{MHz}, \mathrm{CDCl}_{3}\right)$ $\delta$ 139.0, 135.8, 135.7, 133.0, 130.1, 128.5, 128.03, 128.00, 127.7, 127.6, 87.3, 84.4, 73.2, $72.8,69.9,61.5,38.0,37.6,35.1,27.0,19.3,18.6,14.9,13.7,10.9$; IR (thin film, $\mathrm{NaCl}$ ) $3490,2960,2930,2858,1454,1428,1362,1112,1094,1006,823,739,701,614 \mathrm{~cm}^{-1}$; LRMS (EI, Na) calcd for $\mathrm{C}_{37} \mathrm{H}_{52} \mathrm{O}_{4} \mathrm{Si}, 611.89 \mathrm{~m} / z(\mathrm{M}+\mathrm{Na})$; observed, $611.55(\mathrm{M}+\mathrm{Na})^{+}$ $m / z$.

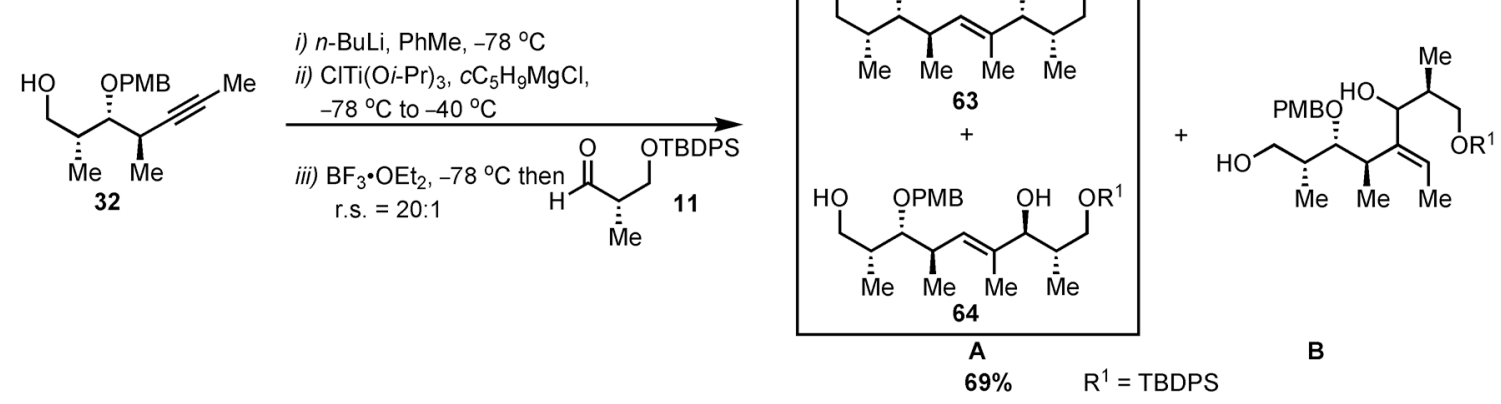

Entry 10 - synthesis of ene-diol 63 and 64 . To a $-78{ }^{\circ} \mathrm{C}$ solution of alkyne 32 (20 mg, $0.072 \mathrm{mmol}$ ) in $0.72 \mathrm{~mL}$ of toluene, was added sequentially, $n$-BuLi (2.27 M in hexanes; $35 \mu \mathrm{L}, 0.080 \mathrm{mmol}), \mathrm{ClTi}(\mathrm{O} i-\mathrm{Pr})_{3}(1.0 \mathrm{M}$ in hexanes; $160 \mu \mathrm{L}, 0.16 \mathrm{mmol})$ and $c-\mathrm{C}_{5} \mathrm{H}_{9} \mathrm{MgCl}(2.0 \mathrm{M}$ in diethyl ether; $160 \mu \mathrm{L}, 0.32 \mathrm{mmol})$ in a dropwise manner via a dry gas-tight syringe. The resulting yellow solution was slowly warmed to $-40{ }^{\circ} \mathrm{C}$ and stirred for $2 \mathrm{~h}$ during which the reaction turned dark brown. The flask was then cooled to $-78{ }^{\circ} \mathrm{C}$ and $\mathrm{BF}_{3} \bullet \mathrm{OEt}_{2}(29 \mu \mathrm{L}, 0.23 \mathrm{mmol})$ was added in a dropwise manner. Following a stirring period of $10 \mathrm{~min}$ at $-78{ }^{\circ} \mathrm{C}$, aldehyde $11(76 \mathrm{mg}, 0.23 \mathrm{mmol})$ was then added as a 
solution in toluene $(0.2 \mathrm{~mL})$ down the side of the flask via a gas tight syringe. The transfer was completed with additional toluene $(2 \times 0.1 \mathrm{~mL})$. Stirring was maintained for $1 \mathrm{~h}$ at $-78{ }^{\circ} \mathrm{C}$, before the addition of saturated $\mathrm{NH}_{4} \mathrm{Cl}$ solution $(0.4 \mathrm{~mL})$. The suspension was allowed to reach ambient temperature before partitioning between EtOAc $(5 \mathrm{~mL})$ and water $(3 \mathrm{~mL})$. The phases were separated and the aqueous layer was extracted with EtOAc $(3 \times 5 \mathrm{~mL})$. The combined organic layer was then washed with sat. $\mathrm{NaHCO}_{3}$ solution $(2 \times 10 \mathrm{~mL})$, brine $(1 \times 10 \mathrm{~mL})$ and dried over anhydrous $\mathrm{Na}_{2} \mathrm{SO}_{4}$. The crude material was purified by flash column chromatography eluting successively with $5 \%$ $(100 \mathrm{~mL}), 7 \%(50 \mathrm{~mL}), 10 \%(100 \mathrm{~mL}), 15 \%(50 \mathrm{~mL}), 20 \%(100 \mathrm{~mL})$ and $30 \%(200$ $\mathrm{mL})$ EtOAc/ hexanes to provide $30 \mathrm{mg}(69 \%)$ of diastereomers 63 and $\mathbf{6 4}$ as the major regioisomer $\mathbf{A}$.

Entry 10 - Regioselectivity data A:B. The residue obtained after a titanium reductive coupling using the above procedure was filtered through a short pad of silica eluting successively with $5 \%(100 \mathrm{~mL}), 7 \%(50 \mathrm{~mL}), 10 \%(50 \mathrm{~mL})$ and $15 \%(50 \mathrm{~mL})$ EtOAc/ hexanes until all traces of the partially reduced olefinic product of alkyne 32 were removed. All remaining organics were removed by washing the silica with $200 \mathrm{~mL}$ of $100 \%$ EtOAc. Analysis of the partially purified mixture by ${ }^{1} \mathrm{H}$ NMR shows an approximately 20:1 mixture of regioisomers. 


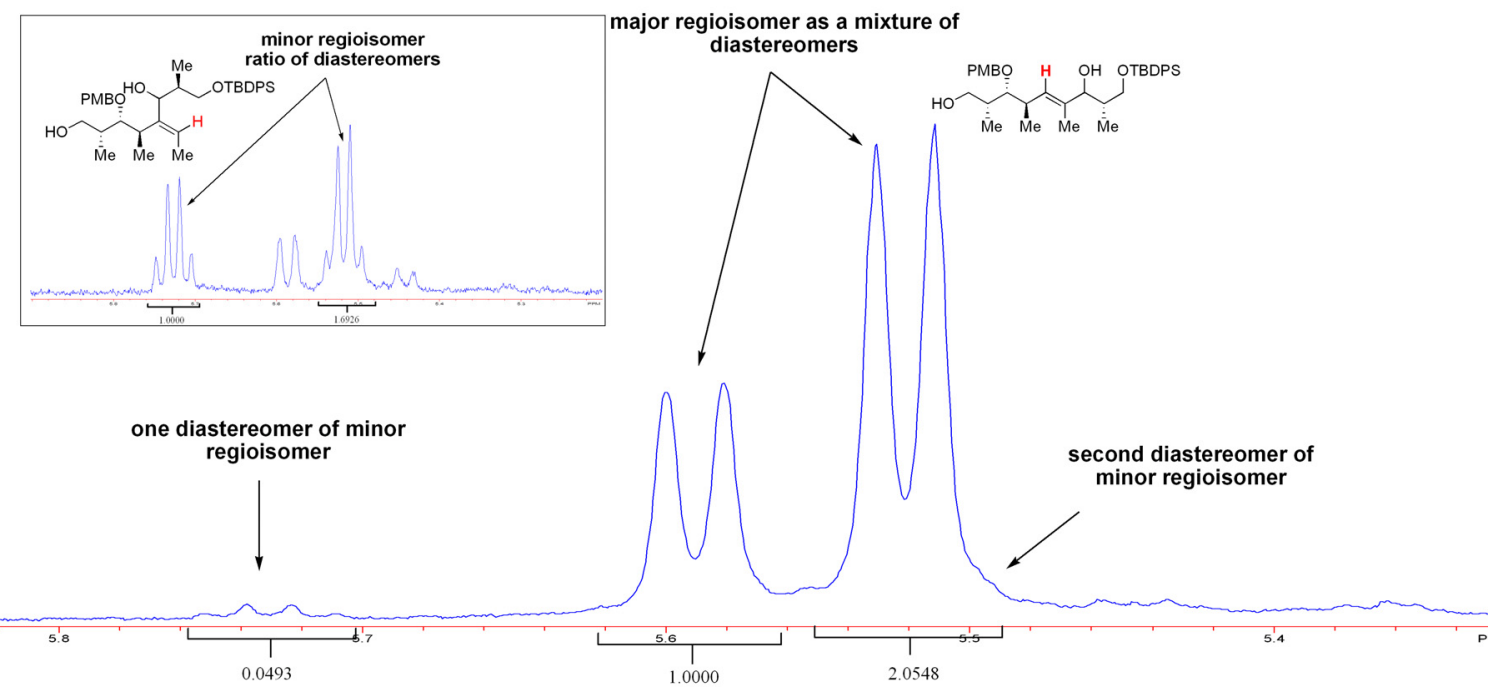

Data for major diastereomer $(E)-(2 S, 3 R, 6 R, 7 R, 8 R)-1-($ tertbutyldiphenylsilanyloxy)-7-(p-methoxybenzyloxy)-2,4,6,8-tetramethylnon-4-ene-3,9diol, 63. $[\alpha]_{589}{ }^{20}+1.31^{\circ}\left(c\right.$ 2.8, $\left.\mathrm{CHCl}_{3}\right) ;{ }^{1} \mathrm{H}$ NMR $\left(500 \mathrm{MHz}, \mathrm{CDCl}_{3}\right) \delta$ 7.72-7.63 (m, 4H), 7.45-7.37 (m, 6H), 7.31-7.21 (m, 2H), 6.92-6.82 (m, 2H), $5.52(\mathrm{~d}, J=9.5 \mathrm{~Hz}, 1 \mathrm{H})$, $4.58(\mathrm{~A}$ of $\mathrm{AB}, J=11.0 \mathrm{~Hz}, 1 \mathrm{H}), 4.50(\mathrm{~B}$ of $\mathrm{AB}, J=11.0 \mathrm{~Hz}, 1 \mathrm{H}), 4.12(\mathrm{~d}, J=6.2 \mathrm{~Hz}$, $1 \mathrm{H}), 3.80(\mathrm{~s}, 3 \mathrm{H}), 3.61-3.57(\mathrm{~m}, 3 \mathrm{H}), 3.52(\mathrm{dd}, J=10.5,5.0 \mathrm{~Hz}, 1 \mathrm{H}), 3.41-3.39(\mathrm{~m}, 1 \mathrm{H})$, 2.78-2.72 (m, 1H), 2.00-1.93 (m, 1H), 1.90-1.82 (m, 1H), $1.57(\mathrm{~s}, 3 \mathrm{H}), 1.08(\mathrm{~s}, 9 \mathrm{H}), 0.96$ $(\mathrm{d}, J=6.9 \mathrm{~Hz}, 3 \mathrm{H}), 0.95(\mathrm{~d}, J=6.8 \mathrm{~Hz}, 3 \mathrm{H}), 0.92(\mathrm{~d}, J=6.8 \mathrm{~Hz}, 3 \mathrm{H}) ;{ }^{13} \mathrm{C} \mathrm{NMR}(126$

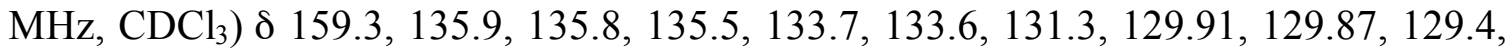
$129.2,127.9,84.7,78.7,73.8,67.9,66.5,55.5,38.3,37.9,35.0,27.1,19.5,18.5,13.0$, 12.0, 11.6; IR (thin film, NaCl) 3401, 2959, 2929, 2858, 1514, 1458, 1427, 1248, 1113 , 1033, 823, 739, $702 \mathrm{~cm}^{-1}$; LRMS (EI, Na) calcd for $\mathrm{C}_{37} \mathrm{H}_{52} \mathrm{O}_{5} \mathrm{Si}, 627.89 \mathrm{~m} / z(\mathrm{M}+\mathrm{Na})$; observed, $627.56(\mathrm{M}+\mathrm{Na})^{+} \mathrm{m} / z$.

Data for minor diastereomer (E)-(2S,3S,6R,7R,8R)-1-(tertbutyldiphenylsilanyloxy)-7-(p-methoxybenzyloxy)-2,4,6,8-tetramethylnon-4-ene-3,9- 
diol, 64. $[\alpha]_{589}{ }^{20}+4.8^{\circ}\left(\mathrm{c} 1.33, \mathrm{CHCl}_{3}\right) ;{ }^{1} \mathrm{H} \mathrm{NMR}\left(500 \mathrm{MHz}, \mathrm{CDCl}_{3}\right) \delta$ 7.70-7.68 (m, 4H), 7.47-7.39 (m, 6H), 7.27-7.25 (m, 2H), 6.87-6.86 (m, 2H), 5.59 (d, $J=10.0 \mathrm{~Hz}, 1 \mathrm{H})$, $4.59(\mathrm{~A}$ of $\mathrm{AB}, J=10.0 \mathrm{~Hz}, 1 \mathrm{H}), 4.50(\mathrm{~B}$ of $\mathrm{AB}, J=10.0 \mathrm{~Hz}, 1 \mathrm{H}), 3.95(\mathrm{~d}, J=8.3 \mathrm{~Hz}$, 1H), $3.80(\mathrm{~s}, 3 \mathrm{H}), 3.78$ (dd, $J=10.1,4.0 \mathrm{~Hz}, 1 \mathrm{H}), 3.66-3.63(\mathrm{~m}, 1 \mathrm{H}), 3.58$ (dd, $J=10.5$, $7.0 \mathrm{~Hz}, 1 \mathrm{H}), 3.49$ (dd, $J=10.7,5.1 \mathrm{~Hz}, 1 \mathrm{H}), 3.40$ (dd, $J=4.6,4.6 \mathrm{~Hz}, 1 \mathrm{H}), 2.82-2.75$ (m, 1H), 2.00-1.90 (m, 2H), 1.67 (s, 3H), 1.07 (s, 9H), 1.05 (d, $J=6.9 \mathrm{~Hz}, 3 \mathrm{H}), 0.97$ (d, $J=$ $7.0 \mathrm{~Hz}, 3 \mathrm{H}), 0.67(\mathrm{~d}, J=6.9 \mathrm{~Hz}, 3 \mathrm{H}) ;{ }^{13} \mathrm{C} \mathrm{NMR}\left(126 \mathrm{MHz}, \mathrm{CDCl}_{3}\right) \delta 159.3,135.84$, $135.83,135.8,133.0,133.6,131.3,131.2,130.1,129.4,128.02,128.01,114.0,84.6,84.0$ 73.9, 69.5, 55.5, 38.2, 37.7, 35.2, 27.0, 19.3, 18.7, 13.9, 12.0, 11.6; IR (thin film, $\mathrm{NaCl}$ ) $3430,2959,2930,2860,1514,1471,1428,1248,1113,1036,822,742,702,668,613$ $\mathrm{cm}^{-1}$; LRMS (EI, Na) calcd for $\mathrm{C}_{37} \mathrm{H}_{52} \mathrm{O}_{5} \mathrm{Si}, 627.89 \mathrm{~m} / \mathrm{z}(\mathrm{M}+\mathrm{Na}$ ); observed, 627.49 (M $+\mathrm{Na})^{+} m / z$.
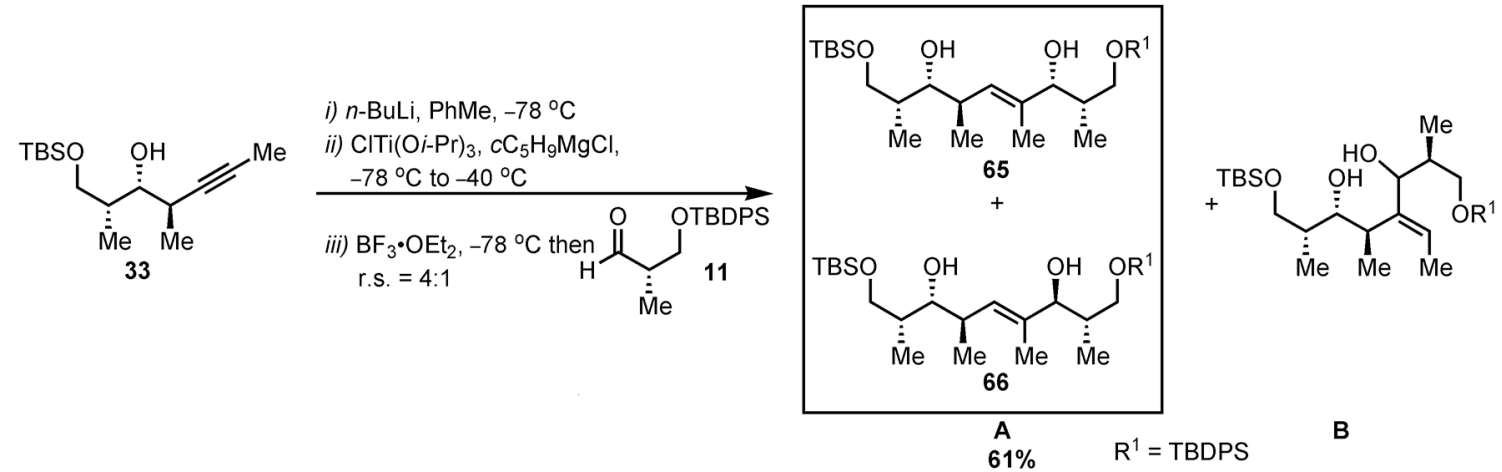

Entry 11 - synthesis of ene-diol 65 and 66. To a $-78{ }^{\circ} \mathrm{C}$ solution of alkyne 33 (20 mg, $0.074 \mathrm{mmol}$ ) in $0.74 \mathrm{~mL}$ of toluene, was added sequentially, $n$-BuLi (2.27 M in hexanes; $36 \mu \mathrm{L}, 0.08 \mathrm{mmol}), \mathrm{ClTi}(\mathrm{O} i-\mathrm{Pr})_{3}(1.0 \mathrm{M}$ in hexanes; $160 \mu \mathrm{L}, 0.16 \mathrm{mmol})$ and $c$ $\mathrm{C}_{5} \mathrm{H}_{9} \mathrm{MgCl}(2.0 \mathrm{M}$ in diethyl ether; $160 \mu \mathrm{L}, 0.32 \mathrm{mmol})$ in a dropwise manner via a dry gas-tight syringe. The resulting yellow solution was slowly warmed to $-40{ }^{\circ} \mathrm{C}$ and stirred for $2 \mathrm{~h}$ during which the reaction turned dark brown. The flask was then cooled to $-78{ }^{\circ} \mathrm{C}$ 
and $\mathrm{BF}_{3} \bullet \mathrm{OEt}_{2}(30 \mu \mathrm{L}, 0.24 \mathrm{mmol})$ was added in a dropwise manner. Following a stirring period of $10 \mathrm{~min}$ at $-78{ }^{\circ} \mathrm{C}$, aldehyde $\mathbf{1 1}(77 \mathrm{mg}, 0.24 \mathrm{mmol})$ was then added as a solution in toluene $(0.2 \mathrm{~mL})$ down the side of the flask via a gas tight syringe. The transfer was completed with additional toluene $(2 \times 0.1 \mathrm{~mL})$. Stirring was maintained for $1 \mathrm{~h}$ at $-78{ }^{\circ} \mathrm{C}$, before the addition of saturated $\mathrm{NH}_{4} \mathrm{Cl}$ solution $(0.4 \mathrm{~mL})$. The suspension was allowed to reach ambient temperature before partitioning between EtOAc $(5 \mathrm{~mL})$ and water $(3 \mathrm{~mL})$. The phases were separated and the aqueous layer was extracted with EtOAc $(3 \times 5 \mathrm{~mL})$. The combined organic layer was then washed with sat. $\mathrm{NaHCO}_{3}$ solution $(2 \times 10 \mathrm{~mL})$, brine $(1 \times 10 \mathrm{~mL})$ and dried over anhydrous $\mathrm{Na}_{2} \mathrm{SO}_{4}$. The crude material was purified by flash column chromatography eluting successively with $2 \%$ $(100 \mathrm{~mL}), 4 \%(100 \mathrm{~mL}), 7 \%(50 \mathrm{~mL}), 10 \%(50 \mathrm{~mL}), 15 \%(100 \mathrm{~mL})$ and $20 \%(100$ $\mathrm{mL}$ ) EtOAc/ hexanes to provide $27 \mathrm{mg}(61 \%)$ of diastereomers $\mathbf{6 5}$ and $\mathbf{6 6}$ as the major regioisomer $\mathbf{A}$.

Entry 11 - Regioselectivity data A:B. The residue obtained after a titanium reductive coupling using the above procedure was filtered through a short pad of silica eluting successively with $2 \%(100 \mathrm{~mL}), 4 \%(50 \mathrm{~mL})$ and $6 \%(50 \mathrm{~mL})$ EtOAc/ hexanes until all traces of the partially reducedproduct of alkyne $\mathbf{3 3}$ were removed. All remaining organics were removed by washing the silica with $200 \mathrm{~mL}$ of $100 \%$ EtOAc. Analysis of the partially purified mixture by ${ }^{1} \mathrm{H}$ NMR shows an approximately 4:1 mixture of regioisomers.

Data for major diastereomer $(E)-(2 S, 3 R, 6 R, 7 R, 8 R)-1-($ tertbutyldiphenylsilanyloxy)-9-(tert-butyldimethylsilanyloxy)-2,4,6,8-tetramethylnon-4ene-3,9-diol, 65. $[\alpha]_{589}{ }^{20}+6.3^{\circ}\left(c\right.$ 1.7, $\left.\mathrm{CHCl}_{3}\right) ;{ }^{1} \mathrm{H}$ NMR $\left(500 \mathrm{MHz}, \mathrm{CDCl}_{3}\right) \delta$ 7.79-7.66 
(m, 4H), 7.44-7.38 (m, 6H), $5.40(\mathrm{~d}, J=9.5 \mathrm{~Hz}, 1 \mathrm{H}), 4.20(\mathrm{~s}, 1 \mathrm{H}), 3.69-3.64(\mathrm{~m}, 4 \mathrm{H})$, $3.52(\mathrm{~d}, J=8.6 \mathrm{~Hz}, 1 \mathrm{H}), 2.57-2.53(\mathrm{~m}, 1 \mathrm{H}), 2.41-2.10(\mathrm{~s} \mathrm{br}, 2 \mathrm{H}), 1.89-1.79(\mathrm{~m}, 2 \mathrm{H}), 1.59$ (s, 3H), $1.08(\mathrm{~s}, 9 \mathrm{H}), 0.96-0.91(\mathrm{~m}, 15 \mathrm{H}), 0.84(\mathrm{~d}, J=6.7 \mathrm{~Hz}, 3 \mathrm{H}), 0.07(\mathrm{~s}, 6 \mathrm{H}) ;{ }^{13} \mathrm{C}$ NMR (126 MHz, $\left.\mathrm{CDCl}_{3}\right) \delta 137.3,135.9,135.8,133.6,133.5,129.96,129.93,129.1$, $127.9,78.3,68.1,68.0,37.9,36.9,36.1,27.1,26.2,19.5,18.5,17.2,13.6,11.1,9.7$, -5.2; IR (thin film, NaCl) 3434, 2959, 2930, 2858, 1514, 1256, 1113, 1094, 1006, 836, 778, 701, $614 \mathrm{~cm}^{-1}$; LRMS (EI, Na) calcd for $\mathrm{C}_{33} \mathrm{H}_{58} \mathrm{O}_{4} \mathrm{Si}, 622.00 \mathrm{~m} / z(\mathrm{M}+\mathrm{Na})$; observed, $622.64(\mathrm{M}+\mathrm{Na})^{+} \mathrm{m} / z$.

Entry 11 - Characterization data for 66. Due to contamination of enol-1,5-diol 66 with an unidentified impurity, characterization was performed on triol 67 obtained after a selective removal of the TBS group.

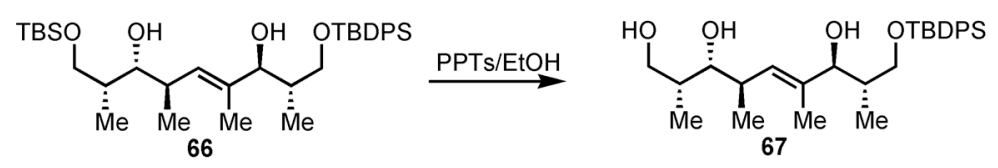

Data for triol 67. $[\alpha]_{589}{ }^{20}+22.4^{\circ}\left(c 0.59, \mathrm{CHCl}_{3}\right) ;{ }^{1} \mathrm{H} \mathrm{NMR}\left(500 \mathrm{MHz}, \mathrm{CDCl}_{3}\right) \delta$ 7.71-7.68 (m, 4H), 7.48-7.39 (m, 6H), $5.31(\mathrm{~d}, J=9.7 \mathrm{~Hz}, 1 \mathrm{H}), 3.98(\mathrm{~d}, J=8.2 \mathrm{~Hz}, 1 \mathrm{H})$, $3.82(\mathrm{dd}, J=10.2,3.9 \mathrm{~Hz}, 1 \mathrm{H}), 3.76(\mathrm{dd}, J=10.7,4.1 \mathrm{~Hz}, 1 \mathrm{H}), 3.69(\mathrm{dd}, J=10.6,5.7$ $\mathrm{Hz}, 1 \mathrm{H}), 3.65(\mathrm{dd}, J=10.1,2.3 \mathrm{~Hz}, 1 \mathrm{H}), 3.51(\mathrm{dd}, J=9.0,2.4 \mathrm{~Hz}, 1 \mathrm{H}), 2.66-2.58(\mathrm{~m}$, 1H), 2.00-2.92 (m, 1H), 1.92-1.83 (m, 1H), $1.70(\mathrm{~d}, J=0.8 \mathrm{~Hz}, 3 \mathrm{H}), 1.08$ (s, 9H), 1.01 (d, $J=7.0 \mathrm{~Hz}, 3 \mathrm{H}), 0.94(\mathrm{~d}, J=6.7 \mathrm{~Hz}, 3 \mathrm{H}), 0.72(\mathrm{~d}, J=6.9 \mathrm{~Hz}, 3 \mathrm{H}) ;{ }^{13} \mathrm{C} \mathrm{NMR}(126 \mathrm{MHz}$, $\left.\mathrm{CDCl}_{3}\right) \delta 139.4,135.84,135.82,132.9,130.8,130.2,128.1,83.8,77.9,69.4,67.9,37.4$, 36.4, 36.0, 27.0, 19.3, 16.9, 14.1, 14.0, 12.2, 9.2; IR (thin film, NaCl) 3411, 2960, 2929, $2858,1458,1427,1113,1083,1024,823,740,701 \mathrm{~cm}^{-1}$; LRMS (EI, Na) calcd for $\mathrm{C}_{29} \mathrm{H}_{44} \mathrm{O}_{4} \mathrm{Si}$, $507.74 \mathrm{~m} / z(\mathrm{M}+\mathrm{Na})$; observed, $507.47(\mathrm{M}+\mathrm{Na})^{+} \mathrm{m} / z$. 

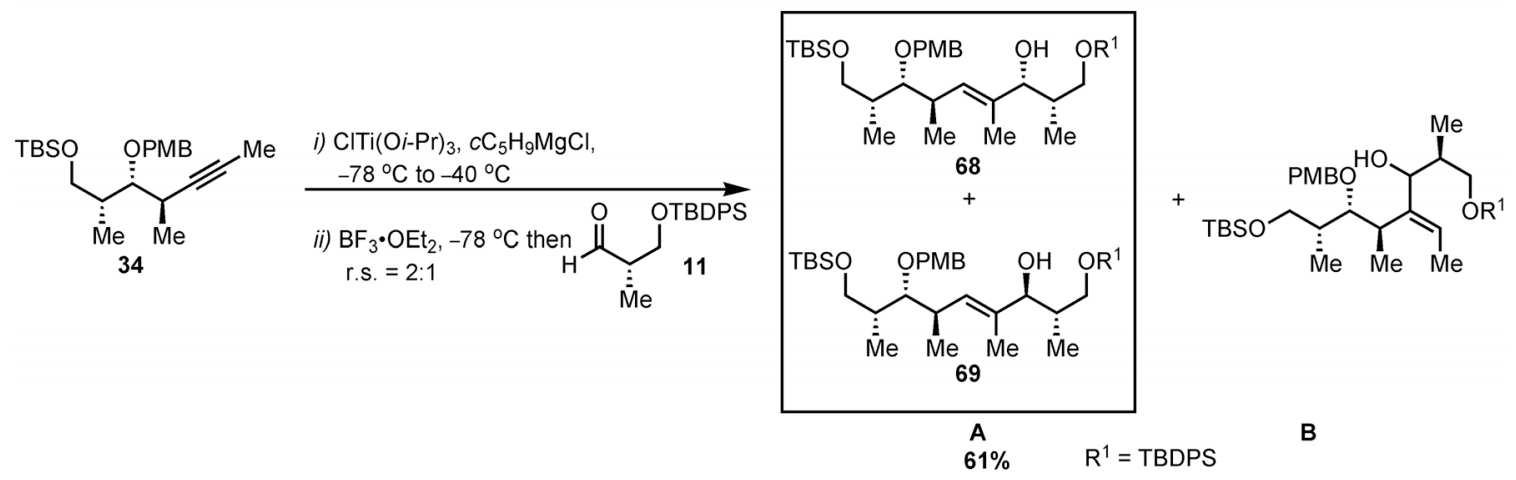

Entry 12 - synthesis of allylic alcohols 68 and 69. To a $-78{ }^{\circ} \mathrm{C}$ solution of alkyne 34 (20 mg, $0.052 \mathrm{mmol})$ in $0.74 \mathrm{~mL}$ of toluene, was added sequentially, ClTi(O $i$ $\operatorname{Pr})_{3}(1.0 \mathrm{M}$ in hexanes; $110 \mu \mathrm{L}, 0.11 \mathrm{mmol})$ and $c-\mathrm{C}_{5} \mathrm{H}_{9} \mathrm{MgCl}(2.0 \mathrm{M}$ in diethyl ether; $110 \mu \mathrm{L}, 0.22 \mathrm{mmol}$ ) in a dropwise manner via a dry gas-tight syringe. The resulting yellow solution was slowly warmed to $-40{ }^{\circ} \mathrm{C}$ and stirred for $2 \mathrm{~h}$ during which the reaction turned dark brown. The flask was then cooled to $-78{ }^{\circ} \mathrm{C}$ and $\mathrm{BF}_{3} \bullet \mathrm{OEt}_{2}(14 \mu \mathrm{L}$, $0.11 \mathrm{mmol}$ ) was added in a dropwise manner. Following a stirring period of $10 \mathrm{~min}$ at $-78{ }^{\circ} \mathrm{C}$, aldehyde $11(54 \mathrm{mg}, 0.17 \mathrm{mmol})$ was then added as a solution in toluene $(0.2$ $\mathrm{mL}$ ) down the side of the flask via a gas tight syringe. The transfer was completed with additional toluene $(2 \times 0.1 \mathrm{~mL})$. Stirring was maintained for $1 \mathrm{~h}$ at $-78{ }^{\circ} \mathrm{C}$, before the addition of saturated $\mathrm{NH}_{4} \mathrm{Cl}$ solution $(0.4 \mathrm{~mL})$. The suspension was allowed to reach ambient temperature before partitioning between EtOAc $(5 \mathrm{~mL})$ and water $(3 \mathrm{~mL})$. The phases were separated and the aqueous layer was extracted with EtOAc $(3 \times 5 \mathrm{~mL})$. The combined organic layer was then washed with sat. $\mathrm{NaHCO}_{3}$ solution $(2 \times 10 \mathrm{~mL})$, brine $(1 \times 10 \mathrm{~mL})$ and dried over anhydrous $\mathrm{Na}_{2} \mathrm{SO}_{4}$. The crude material was purified by flash column chromatography eluting successively with $2 \%(100 \mathrm{~mL}), 4 \%$ (100 mL), $7 \%$ (50 $\mathrm{mL}), 10 \%(100 \mathrm{~mL}), 15 \%(100 \mathrm{~mL})$ and $20 \%(100 \mathrm{~mL})$ EtOAc/ hexanes to provide 23 mg $(61 \%)$ of diastereomers 68 and 69 as the major regioisomer $\mathbf{A}$. 
Entry 12 - Regioselectivity data A:B. The residue obtained after a titanium reductive coupling using the above procedure was filtered through a short pad of silica eluting successively with $2 \%(100 \mathrm{~mL}), 4 \%(50 \mathrm{~mL})$ and $6 \%(50 \mathrm{~mL})$ EtOAc/ hexanes until all traces of the partially reduced olefinic product of alkyne $\mathbf{3 3}$ were removed. All remaining organics were removed by washing the silica with $200 \mathrm{~mL}$ of $100 \%$ EtOAc. Analysis of the partially purified mixture by ${ }^{1} \mathrm{H}$ NMR shows an approximately 2:1 mixture of regioisomers.

Entry 12 - Characterization data for 68. Due to contamination of enol 68 with an unidentified impurity, characterization was performed on ene-diol 63 (see entry 10) obtained after a selective removal of the TBS group.

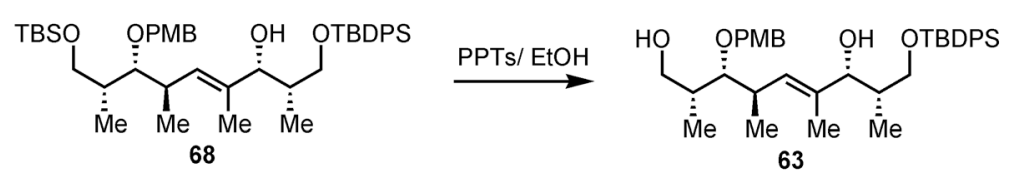

Data for minor diastereomer $(E)-(2 S, 3 S, 6 R, 7 R, 8 R)-1-($ tertbutyldiphenylsilanyloxy)-7-(p-methoxybenzyloxy)-9-(tert-butyldimethylsilanyloxy)2,4,6,8-tetramethylnon-4-ene-3-ol, 69. $[\alpha]_{589}{ }^{20}-2.1^{\circ}\left(c \quad 0.49, \mathrm{CHCl}_{3}\right) ;{ }^{1} \mathrm{H}$ NMR $(500$ $\left.\mathrm{MHz}, \mathrm{CDCl}_{3}\right) \delta$ 7.70-7.68 (m, 4H), 7.47-7.39 (m, 6H), 7.26-7.24 (m, 2H), 6.86-6.84 (m, 2H), $5.54(\mathrm{~d}, J=9.5 \mathrm{~Hz}, 1 \mathrm{H}), 4.55(\mathrm{~A}$ of $\mathrm{AB}, J=10.9 \mathrm{~Hz}, 1 \mathrm{H}), 4.48(\mathrm{~B}$ of $\mathrm{AB}, J=10.9$ Hz, 1H), 3.94 (d, $J=8.6 \mathrm{~Hz}, 1 \mathrm{H}), 3.80$ (s, 3H), 3.77 (dd, $J=10.2,4.1 \mathrm{~Hz}, 1 \mathrm{H}), 3.63$ (dd, $J=10.0,8.0 \mathrm{~Hz}, 1 \mathrm{H}), 3.49(\mathrm{dd}, J=9.8,6.2 \mathrm{~Hz}, 1 \mathrm{H}), 3.42(\mathrm{dd}, J=9.7,5.9 \mathrm{~Hz}, 1 \mathrm{H}), 3.37$ $(\mathrm{dd}, J=5.3,5.3 \mathrm{~Hz}, 1 \mathrm{H}), 2.76-2.69(\mathrm{~m}, 1 \mathrm{H}), 1.97-1.92(\mathrm{~m}, 1 \mathrm{H}), 1.80-1.76(\mathrm{~m}, 1 \mathrm{H}), 1.65$ $(\mathrm{d}, J=0.8 \mathrm{~Hz}, 3 \mathrm{H}), 1.07(\mathrm{~s}, 9 \mathrm{H}), 1.03(\mathrm{~d}, J=7.0 \mathrm{~Hz}, 3 \mathrm{H}), 0.96(\mathrm{~d}, J=6.8 \mathrm{~Hz}, 3 \mathrm{H}), 0.90$ $(\mathrm{s}, 9 \mathrm{H}), 0.62(\mathrm{~d}, J=6.9 \mathrm{~Hz}, 3 \mathrm{H}), 0.04(\mathrm{~s}, 3 \mathrm{H}), 0.03(\mathrm{~s}, 3 \mathrm{H}) ;{ }^{13} \mathrm{C} \mathrm{NMR}\left(126 \mathrm{MHz}, \mathrm{CDCl}_{3}\right)$ $\delta 159.1,135.8,135.4,133.0,131.9,131.8,130.1,129.2,128.03,128.01,113.8,84.3$, 
$83.6,74.5,69.7,65.8,39.2,37.6,35.7,27.0,26.1,19.3,18.52,18.48,13.9,12.5,11.3$, -5.17, -5.19; IR (thin film, $\mathrm{NaCl}$ ) 3487, 2957, 2929, 2858, 1464, 1249, 1113, 1113, 1086, 1036, 832, 771, 701, $668 \mathrm{~cm}^{-1}$; LRMS (EI, Na) calcd for $\mathrm{C}_{43} \mathrm{H}_{66} \mathrm{O}_{5} \mathrm{Si}_{2}, 742.15 \mathrm{~m} / \mathrm{z}$ $(\mathrm{M}+\mathrm{Na})$; observed, $742.71(\mathrm{M}+\mathrm{Na})^{+} \mathrm{m} / z$.

2. Assembly of the seco-acid precursor of (9S)-dihydroerythronolide $A\left(2^{\text {nd }}\right.$ generation approach).

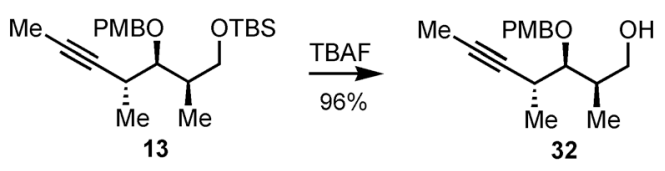

$(2 R, 3 R, 4 R)-3-(p-m e t h o x y b e n z y l o x y)-2,4-d i m e t h y l-5-h e p t y n-1-o l, 32$.

To a stirring solution of $\mathbf{1 3}(150 \mathrm{mg}, 0.39 \mathrm{mmol})$ in $3.9 \mathrm{~mL}$ of THF, was added TBAF (1.0 $\mathrm{M}$ in THF; $0.58 \mathrm{~mL}, 0.58 \mathrm{mmol})$ in a dropwise manner. The reaction was stirred overnight at room temperature before pouring in a separatory funnel containing $10 \mathrm{~mL}$ of EtOAc and $8 \mathrm{~mL}$ of sat. $\mathrm{NaHCO}_{3}$ solution. The aqueous layer was extracted with EtOAc $(2 \times 10 \mathrm{~mL})$. The combined organic layer was then washed with brine $(1 \times 20 \mathrm{~mL})$ and dried over anhydrous $\mathrm{Na}_{2} \mathrm{SO}_{4}$. The crude material was purified by flash column chromatography on silica gel eluting successively with $30 \%$ EtOAc -hexanes to provide $103 \mathrm{mg}(96 \%)$ of a pure $32[\alpha]_{589}{ }^{20}-19.4^{\circ}\left(\mathrm{c} 2.1, \mathrm{CHCl}_{3}\right) ;{ }^{1} \mathrm{H} \mathrm{NMR}\left(500 \mathrm{MHz}, \mathrm{CDCl}_{3}\right) \delta$ 7.32-7.30 (m, 2H), 6.89-6.87 (m, 2H), $4.74(\mathrm{~A}$ of AB, $J=11.0 \mathrm{~Hz}, 1 \mathrm{H}), 4.57$ (B of AB, $J$ $=11.0 \mathrm{~Hz}, 1 \mathrm{H}), 3.81(\mathrm{~s}, 3 \mathrm{H}), 3.66-3.59(\mathrm{~m}, 2 \mathrm{H}), 3.42(\mathrm{dd}, J=6.0,4.4 \mathrm{~Hz}, 1 \mathrm{H}), 2.81-2.75$ (m, 1H), 2.07-1.94 (m, 1H), 1.88, (s br, 1H), $1.82(\mathrm{~d}, J=2.4 \mathrm{~Hz}, 3 \mathrm{H}), 1.17(\mathrm{~d}, J=7.1$ $\mathrm{Hz}, 3 \mathrm{H}), 0.94(\mathrm{~d}, J=7.0 \mathrm{~Hz}, 3 \mathrm{H}) ;{ }^{13} \mathrm{C} \mathrm{NMR}\left(126 \mathrm{MHz}, \mathrm{CDCl}_{3}\right) \delta 159.4,130.9$ 129.9, 114.0, 83.1, 82.0, 77.3, 73.6, 60.1, 55.5, 37.4, 28.8, 18.3, 11.9, 3.9; IR (thin film, $\mathrm{NaCl}$ ) 
3415, 2929, 2917, 2858, 1514, 1456, 1249, 1173, 1035, $821 \mathrm{~cm}^{-1}$; LRMS (EI, Na) calcd for $\mathrm{C}_{17} \mathrm{H}_{24} \mathrm{O}_{3}, 299.37 \mathrm{~m} / z(\mathrm{M}+\mathrm{Na})$; observed, $299.20(\mathrm{M}+\mathrm{Na})^{+} \mathrm{m} / \mathrm{z}$

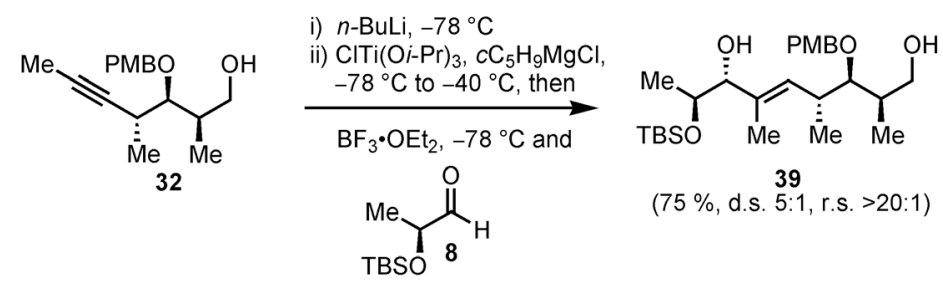

\section{(E)-(2R,3R,4R,7R,8S)-3-(p-methoxybenzyloxy)-8-(tert-butyldimethyl}

silanyloxy)-2,4,6-trimethylnon-5-ene-1,7-diol, 39. To a $-78{ }^{\circ} \mathrm{C}$ solution of alkyne 32 (300 mg, $1.09 \mathrm{mmol})$ in $11 \mathrm{~mL}$ of toluene, was added sequentially $n$-BuLi $(2.5 \mathrm{M}$ in hexanes; $0.48 \mathrm{~mL}, 1.2 \mathrm{mmol}), \mathrm{ClTi}(\mathrm{O} i-\mathrm{Pr})_{3}(1.0 \mathrm{M}$ in hexanes; $2.4 \mathrm{~mL}, 2.4 \mathrm{mmol})$ and $c$ $\mathrm{C}_{5} \mathrm{H}_{9} \mathrm{MgCl}(2.0 \mathrm{M}$ in diethyl ether; $2.4 \mathrm{~mL}, 4.8 \mathrm{mmol})$ in a dropwise manner via a dry gas-tight syringe. The resulting yellow solution was slowly warmed to $-40{ }^{\circ} \mathrm{C}$ and stirred for $1 \mathrm{~h}$ during which the reaction turned dark brown. The flask was then cooled to $-78{ }^{\circ} \mathrm{C}$ and $\mathrm{BF}_{3} \cdot \mathrm{OEt}_{2}(0.44 \mathrm{~mL}, 3.5 \mathrm{mmol})$ was added in a dropwise manner. Following a stirring period of $10 \mathrm{~min}$ at $-78{ }^{\circ} \mathrm{C}$, aldehyde $8(660 \mathrm{mg}, 3.5 \mathrm{mmol})$ was then added as a solution in toluene $(0.5 \mathrm{~mL})$ down the side of the flask via a gas tight syringe. The transfer was completed with additional toluene $(2 \times 0.5 \mathrm{~mL})$. Stirring was maintained for $1 \mathrm{~h}$ at -78 ${ }^{\circ} \mathrm{C}$. Saturated $\mathrm{NH}_{4} \mathrm{Cl}$ solution $(7 \mathrm{~mL})$ was then added and the suspension was allowed to reach ambient temperature before partitioning between EtOAc $(20 \mathrm{~mL})$ and water $(10$ $\mathrm{mL})$. The phases were separated and the aqueous layer was extracted with EtOAc $(3 \times 20$ $\mathrm{mL})$. The combined organic layer was then washed with sat. $\mathrm{NaHCO}_{3}$ solution $(2 \times 40$ $\mathrm{mL})$, brine $(1 \times 40 \mathrm{~mL})$ and dried over anhydrous $\mathrm{Na}_{2} \mathrm{SO}_{4}$. The crude material was purified by flash column chromatography on silica gel eluting successively with $5 \%, 10$ $\%, 15 \%, 20 \%$ and $30 \%$ EtOAc -hexanes to provide $379 \mathrm{mg}$ (75\%) of a diastereomeric 
mixture of 39 (d.s. $=5: 1$ at C7). $[\alpha]_{589}{ }^{20}+1.98^{\circ}\left(c 0.81, \mathrm{CHCl}_{3}\right) ;{ }^{1} \mathrm{H}$ NMR $(500 \mathrm{MHz}$, $\left.\mathrm{CDCl}_{3}\right) \delta$ 7.27-7.25 (m, 2H), 6.87-6.86 (m, 2H), $5.64(\mathrm{~d}, J=9.8 \mathrm{~Hz}, 1 \mathrm{H}), 4.59$ (A of AB, $J=11.0 \mathrm{~Hz}, 1 \mathrm{H}), 4.49(\mathrm{~B}$ of AB, $J=11.0 \mathrm{~Hz}, 1 \mathrm{H}), 3.98-3.94(\mathrm{~m}, 2 \mathrm{H}), 3.81(\mathrm{~s}, 3 \mathrm{H}), 3.59$ (dd, $J=10.8,7.0 \mathrm{~Hz}, 1 \mathrm{H}), 3.54(\mathrm{dd}, J=10.6,4.9 \mathrm{~Hz}, 1 \mathrm{H}), 3.40(\mathrm{dd}, J=6.3,3.9 \mathrm{~Hz}, 1 \mathrm{H})$, 2.82-2.76 (m, 1H), 2.35-2.00 (s br, 2H), 2.00-1.93 (m, 1H), $1.63(\mathrm{~d}, J=1.1 \mathrm{~Hz}, 3 \mathrm{H})$, 1.00-0.96 (m, 9H), 0.91 (s, 9H), $0.096(\mathrm{~s}, 3 \mathrm{H}), 0.091$ (s, 3H); ${ }^{13} \mathrm{C} \mathrm{NMR}(126 \mathrm{MHz}$, $\left.\mathrm{CDCl}_{3}\right) \delta 159.3,132.8,131.3,129.8,129.6,129.4,113.9,84.7,79.0,73.8,70.6,66.6$, $55.5,37.7,35.0,26.0,18.3,17.0,14.3,11.7,-4.3,-4.7$; IR (thin film, $\mathrm{NaCl}$ ) 3422, 2957, 2929, 2856, 1514, 1463, 1249, 1086, 1035, 835, 777, $668 \mathrm{~cm}^{-1}$; LRMS (EI, Na) calcd for $\mathrm{C}_{26} \mathrm{H}_{46} \mathrm{O}_{5} \mathrm{Si}, 489.73 \mathrm{~m} / z(\mathrm{M}+\mathrm{Na})$; observed, $489.48(\mathrm{M}+\mathrm{Na})^{+} \mathrm{m} / z$.

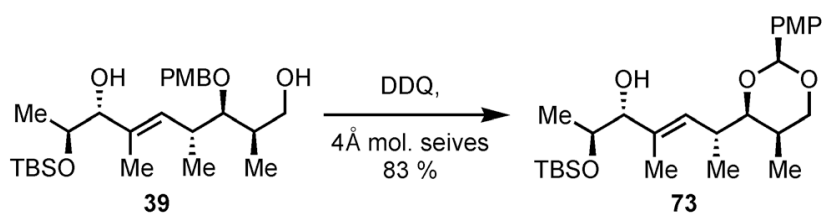

\section{(E)-(2R,3R,4R,7R,8S)-1,3-O-(4-methoxy-benzylidene)-8-(tert-}

butyldimethylsilanyloxy)-2,4,6-trimethylnon-5-ene-7-ol, 73. To a stirring mixture of 39 (280 mg, $0.64 \mathrm{mmol})$ and $0.76 \mathrm{mg}$ of activated $4 \AA$ molecular sieves powder in $3.8 \mathrm{~mL}$ of $\mathrm{CH}_{2} \mathrm{Cl}_{2}$ at $0{ }^{\circ} \mathrm{C}$ was added a solution of DDQ $(175 \mathrm{mg}, 0.77 \mathrm{mmol})$ in $11.2 \mathrm{~mL}$ of $\mathrm{CH}_{2} \mathrm{Cl}_{2}$ dropwise via cannula. The resulting slurry was stirred for an additional $20 \mathrm{~min}$ at $0{ }^{\circ} \mathrm{C}$ before filtering through Celite. The filtrate was washed successively with sat $\mathrm{NaHCO}_{3}$ and brine before drying over anhydrous $\mathrm{Na}_{2} \mathrm{SO}_{4}$. The solvent was concentrated and the residue was purified by flash column chromatography eluting with $8 \% \mathrm{EtOAc} /$ hexanes to afford $232 \mathrm{mg}(83 \%)$ of $73 .[\alpha]_{589}{ }^{20}+21.8^{\circ}\left(c 0.82, \mathrm{CHCl}_{3}\right) ;{ }^{1} \mathrm{H}$ NMR (500 $\left.\mathrm{MHz}, \mathrm{C}_{6} \mathrm{D}_{6}\right) \delta$ 7.62-7.59 (m, 2H), 6.83-6.80 (m, 2H), $5.58(\mathrm{~d}, J=9.1 \mathrm{~Hz}, 1 \mathrm{H}), 5.34(\mathrm{~s}$, 
1H), $4.08(\mathrm{~s}, 1 \mathrm{H}), 3.97-3.93(\mathrm{~s}, 1 \mathrm{H}), 3.81-3.79(\mathrm{~m}, 1 \mathrm{H}), 3.68(\mathrm{dd}, J=11.0,1.9 \mathrm{~Hz}, 1 \mathrm{H})$, $3.31(\mathrm{dd}, J=9.7,1.9 \mathrm{~Hz}, 1 \mathrm{H}), 3.26(\mathrm{~s}, 3 \mathrm{H}), 2.74-2.66(\mathrm{~m}, 1 \mathrm{H}), 2.46-2.40(\mathrm{~s} \mathrm{br}, 1 \mathrm{H}), 1.71$ (d, $J=1.1 \mathrm{~Hz}, 3 \mathrm{H}), 1.22-1.18(\mathrm{~m}, 1 \mathrm{H}), 1.16(\mathrm{~m}, 3 \mathrm{H}), 1.06(\mathrm{~d}, J=6.3 \mathrm{~Hz}, 3 \mathrm{H}), 0.89(\mathrm{~s}$, 9H), $0.80(\mathrm{~d}, J=6.8 \mathrm{~Hz}, 3 \mathrm{H}), 0.008(\mathrm{~s}, 3 \mathrm{H}),-0.005(\mathrm{~s}, 3 \mathrm{H}) ;{ }^{13} \mathrm{C} \mathrm{NMR}\left(126 \mathrm{MHz}, \mathrm{C}_{6} \mathrm{D}_{6}\right)$ $\delta 160.2,134.4,132.5,130.2,128.5,128.3,127.9,113.6,102.0,83.9,79.5,73.7,71.6$, 54.6, 34.1, 30.3, 25.9, 18.2, 17.5, 15.6, 14.1, 11.2, -4.5, -4.9; IR (thin film, $\mathrm{NaCl}$ ) 3477, 2958, 2929, 2855, 1519, 1463, 1249, 1108, 1081, 1033, 967, 832, $777 \mathrm{~cm}^{-1}$; LRMS (EI, Na) calcd for $\mathrm{C}_{26} \mathrm{H}_{44} \mathrm{O}_{5} \mathrm{Si}, 487.71 \mathrm{~m} / z(\mathrm{M}+\mathrm{Na})$; observed, $487.42(\mathrm{M}+\mathrm{Na})^{+} \mathrm{m} / \mathrm{z}$.

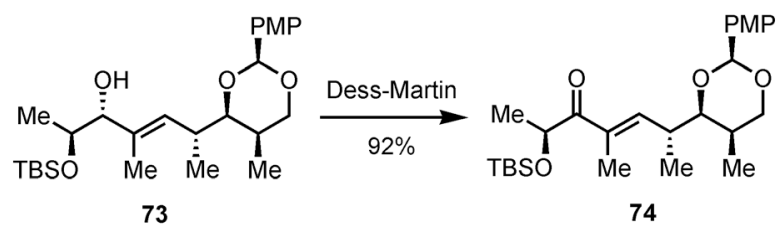

(E)-(2R,3R,4R,8S)-1,3-O-(4-methoxy-benzylidene)-8-(tert-

butyldimethylsilanyloxy)-2,4,6-trimethylnon-5-ene-7-one, 74. To a cooled solution of $73(232 \mathrm{mg}, 0.50 \mathrm{mmol})$ in dichloromethane at $0{ }^{\circ} \mathrm{C}$ was added 1,1,1-triacetoxy-1,1dihydro-1,2-benziodoxol-3-(1H)-one (424 mg, $1.0 \mathrm{mmol})$ at once. After stirring for $1 \mathrm{~h}$ at $0{ }^{\circ} \mathrm{C}$ and $30 \mathrm{~min}$ at $\mathrm{rt}$, the reaction was diluted with $10 \mathrm{~mL}$ of $30 \%$ EtOAc/hex solution. Most of the solvent was evaporated and the residue was diluted $10 \mathrm{~mL}$ of $30 \%$ EtOAc/hex solution. The white cloudy solution was washed with a 1:1 mixture of $10 \%$ $\mathrm{Na}_{2} \mathrm{~S}_{2} \mathrm{O}_{3}$ and sat $\mathrm{NaHCO}_{3}$ until a clear organic layer is obtained. The organic layer was then washed with brine and dried over anhydrous $\mathrm{Na}_{2} \mathrm{SO}_{4}$. The solvent was concentrated and the residue was purified by flash column chromatography eluting with $5 \% \mathrm{EtOAc} /$ hexanes to afford $213 \mathrm{mg}$ of enone 74 (92\%). Enone 74 was immediately used in the next step. 


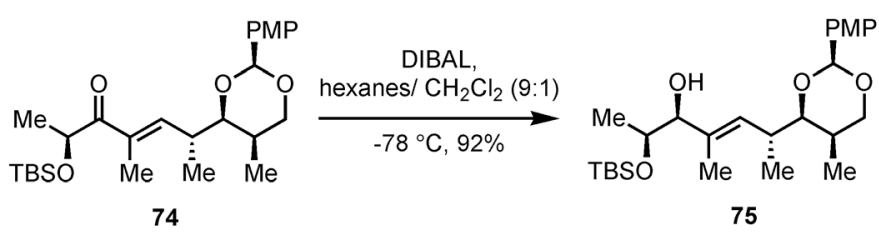

(E)-(2R,3R,4R,7S,8S)-1,3-O-(4-methoxy-benzylidene)-8-(tert-

butyldimethylsilanyloxy)-2,4,6-trimethylnon-5-ene-7-ol, 75. A solution of 74 (210 mg, $0.45 \mathrm{mmol})$ in hexanes/dichloromethane $(9: 1,4.5 \mathrm{ml})$ was cooled to $-78{ }^{\circ} \mathrm{C}$ before adding DIBAL (1.0 $\mathrm{M}$ in hexanes; $1.1 \mathrm{~mL}, 1.1 \mathrm{mmol})$ in a dropwise manner. After 10 min of stirring, $0.5 \mathrm{~mL}$ of methanol was added slowly followed by $2 \mathrm{~mL}$ of saturated Rochelle salt solution. The resulting slurry was warmed to room temperature before pouring into a separatory funnel containing $10 \mathrm{~mL}$ of ethyl acetate and $7 \mathrm{~mL}$ of sat. Rochelle salt solution. The phases were separated and the aqueous layer was extracted with EtOAc $(3 \times 10 \mathrm{~mL})$ and the combined organic layer was washed with saturated $\mathrm{NaHCO}_{3}(2 \times 20 \mathrm{~mL})$, brine and dried over anhydrous $\mathrm{Na}_{2} \mathrm{SO}_{4}$. The solvent was concentrated and the residue was purified by flash column chromatography eluting with 5 $\%$ EtOAc/ hexanes affording $194 \mathrm{mg}$ of $75(92 \%) .[\alpha]_{589}{ }^{20}+61.5^{\circ}\left(c 0.13, \mathrm{CHCl}_{3}\right) ;{ }^{1} \mathrm{H}$

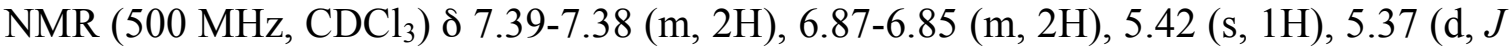
$=8.8 \mathrm{~Hz}, 1 \mathrm{H}), 4.07-4.01(\mathrm{~m}, 1 \mathrm{H}), 3.79(\mathrm{~s}, 3 \mathrm{H}), 3.74-3.69(\mathrm{~m}, 1 \mathrm{H}), 3.67-3.65(\mathrm{~m}, 1 \mathrm{H})$, $3.60(\mathrm{dd}, J=9.4,2.0 \mathrm{~Hz}, 1 \mathrm{H}), 2.72-2.62(\mathrm{~m}, 1 \mathrm{H}), 1.72-1.69(\mathrm{~m}, 1 \mathrm{H}), 1.65(\mathrm{~d}, J=0.95$ $\mathrm{Hz}, 3 \mathrm{H}), 1.20(\mathrm{~d}, J=6.9 \mathrm{~Hz}, 3 \mathrm{H}), 1.03$ (d, $J=6.0 \mathrm{~Hz}, 3 \mathrm{H}), 0.94-0.90$ (m,12 H), 0.079 (s, $6 \mathrm{H}) ;{ }^{13} \mathrm{C}$ NMR $\left(126 \mathrm{MHz}, \mathrm{C}_{6} \mathrm{D}_{6}\right) \delta 160.2,135.6,132.40,132.38,128.3,128.1,127.9$, $113.7,101.8,83.6,83.0,73.7,71.8,54.6,34.2,30.4,26.0,20.4,18.2,15.5,13.1,11.2$, -4.2, -4.6 IR (thin film, $\mathrm{NaCl}$ ) 3544, 2957, 2929, 2856, 1518, 1463, 1249, 1114, 1034, 
832, $777 \mathrm{~cm}^{-1}$; LRMS (EI, Na) calcd for $\mathrm{C}_{26} \mathrm{H}_{44} \mathrm{O}_{5} \mathrm{Si}$, $487.77 \mathrm{~m} / z(\mathrm{M}+\mathrm{Na})$; observed, $487.46(\mathrm{M}+\mathrm{Na})^{+} m / z$.

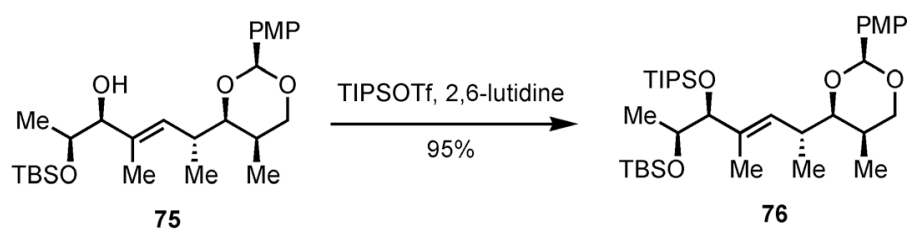

(E)-(2R,3R,4R,7S,8S)-1,3-O-(4-methoxy-benzylidene)-7-(tri-

isopropylsilanyloxy)-8-(tert-butyldimethylsilanyloxy)-2,4,6-trimethylnon-5-ene, 76.

To a cooled solution of enol $75(150 \mathrm{mg}, 0.32 \mathrm{mmol})$ and 2,6-lutidine $(0.11 \mathrm{~mL}, 0.97$ mmol) in dichloromethane $(3.2 \mathrm{~mL})$ at $0{ }^{\circ} \mathrm{C}$, was added TIPS-OTf $(0.13 \mathrm{~mL}, 0.50$ mmol). The reaction was held at $0{ }^{\circ} \mathrm{C}$ for $1 \mathrm{~h}$ before diluting with $20 \%$ EtOAc/ hexanes $(10 \mathrm{~mL})$. The organic layer was then washed with saturated $\mathrm{NaHCO}_{3}(2 \times 10 \mathrm{~mL})$, brine and dried over anhydrous $\mathrm{Na}_{2} \mathrm{SO}_{4}$. The solvent was concentrated and the residue was purified by flash column chromatography eluting with $2 \%$ EtOAc/ hexanes affording $190 \mathrm{mg}$ of $76(95 \%)$. $[\alpha]_{589}{ }^{20}+14.5^{\circ}\left(c 0.64, \mathrm{CHCl}_{3}\right) ;{ }^{1} \mathrm{H} \mathrm{NMR}\left(500 \mathrm{MHz}, \mathrm{C}_{6} \mathrm{D}_{6}\right) \delta$ 7.61-7.58 (m, 2H), 6.87-6.86 (m, 2H), $5.55(\mathrm{~d}, J=9.1 \mathrm{~Hz}, 1 \mathrm{H}), 5.37(\mathrm{~s}, 1 \mathrm{H}), 4.31(\mathrm{~d}, J=$ 4.2 Hz, 1H), 4.09-4.04 (m, 1H), $3.80(\mathrm{dd}, J=11.0,0.9 \mathrm{~Hz}, 1 \mathrm{H}), 3.71(\mathrm{dd}, J=11.0,2.0$ $\mathrm{Hz}, 1 \mathrm{H}), 3.38(\mathrm{dd}, J=9.6,1.9 \mathrm{~Hz}, 1 \mathrm{H}), 3.33(\mathrm{~s}, 3 \mathrm{H}), 2.80-2.72(\mathrm{~m}, 1 \mathrm{H}), 1.87$ (d, $J=1.0$ $\mathrm{Hz}, 3 \mathrm{H}), 1.23-1.20(\mathrm{~m}, 1 \mathrm{H}), 1.19-1.14(\mathrm{~m}, 27 \mathrm{H}), 0.98(\mathrm{~s}, 9 \mathrm{H}), 0.87(\mathrm{~d}, J=6.8 \mathrm{~Hz}, 3 \mathrm{H})$, $0.14(\mathrm{~s}, 3 \mathrm{H}), 0.075(\mathrm{~s}, 3 \mathrm{H}) ;{ }^{13} \mathrm{C} \mathrm{NMR}\left(126 \mathrm{MHz}, \mathrm{C}_{6} \mathrm{D}_{6}\right) \delta$ 160.2, 134.9, 132.6, 130.9, $128.3,128.1,113.6,102.3,84.2,80.1,73.7,73.3,54.7,34.3,30.4,26.1,18.42,18.39$, $18.3,16.0,15.8,12.8,11.2,-4.45,-4.44$; IR (thin film, $\mathrm{NaCl}) 2959,2865,1519,1463$, 1249, 1108, 1000, 883, 834, 774, $680 \mathrm{~cm}^{-1}$; LRMS (EI, Na) calcd for $\mathrm{C}_{35} \mathrm{H}_{64} \mathrm{O}_{5} \mathrm{Si}_{2}$, $644.05 \mathrm{~m} / z(\mathrm{M}+\mathrm{Na})$; observed, $644.62(\mathrm{M}+\mathrm{Na})^{+} \mathrm{m} / z$. 


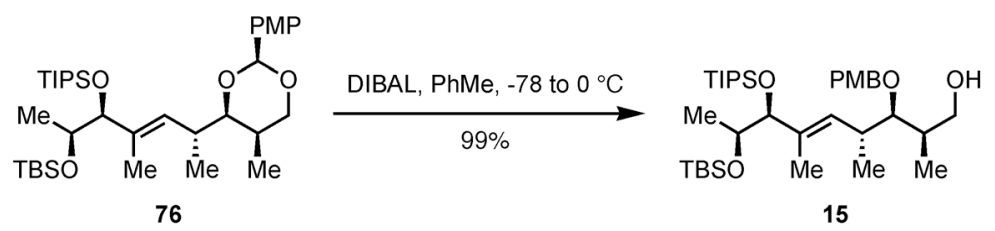

(E)-(2R,3R,4R,7S,8S)-3-(p-methoxybenzyloxy)-7-(tri-isopropylsilanyloxy)-8-di(tert-

butyldimethylsilanyloxy)-2,4,6-trimethylnon-5-ene-1-ol, 15. To a solution of 76 (190

$\mathrm{g}, 0.31 \mathrm{mmol})$ in $3 \mathrm{~mL}$ of toluene at $-78{ }^{\circ} \mathrm{C}$ was added DIBAL (1.0M in hexanes; 0.97

$\mathrm{mL}, 0.97 \mathrm{mmol})$. The reaction was slowly warmed to $0{ }^{\circ} \mathrm{C}$ and kept at this temperature for $30 \mathrm{~min}$. The reaction was cooled to $-78{ }^{\circ} \mathrm{C}$ and $0.5 \mathrm{~mL}$ of methanol was added followed by $1.5 \mathrm{~mL}$ of Rochelle salt solution. The resulting slurry was warmed to room temperature before pouring into a separatory funnel containing $6 \mathrm{~mL}$ of ethyl acetate and $3 \mathrm{~mL}$ of sat. Rochelle salt solution. The phases were separated and the aqueous layer was extracted with EtOAc $(3 \times 6 \mathrm{~mL})$. The combined organic layer was washed with saturated $\mathrm{NaHCO}_{3}(2 \times 15 \mathrm{~mL})$, brine and dried over anhydrous $\mathrm{Na}_{2} \mathrm{SO}_{4}$. The solvent was concentrated and the residue was purified by flash column chromatography eluting with $15 \%$ EtOAc/ hexanes affording $188 \mathrm{mg}$ of $\mathbf{1 5}(99 \%)$.

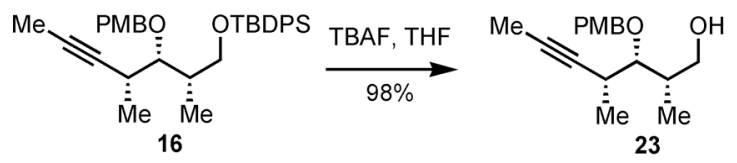

(2S,3S,4R)-3-( $p$-methoxybenzyloxy)-2,4-dimethyl-5-heptyn-1-ol, 23. To a stirring solution of $16(188 \mathrm{mg}, 0.37 \mathrm{mmol})$ in $3.6 \mathrm{~mL}$ of THF, was added TBAF $(1.0 \mathrm{M}$ in THF; $0.55 \mathrm{~mL}, 0.55 \mathrm{mmol}$ ) in a dropwise manner. The reaction was stirred overnight at room temperature before pouring in a separatory funnel containing $10 \mathrm{~mL}$ of EtOAc and $8 \mathrm{~mL}$ of sat. $\mathrm{NaHCO}_{3}$ solution. The aqueous layer was extracted with EtOAc $(2 \times 10$ $\mathrm{mL})$. The combined organic layer was then washed with brine $(1 \times 20 \mathrm{~mL})$ and dried over 
anhydrous $\mathrm{Na}_{2} \mathrm{SO}_{4}$. The crude material was purified by flash column chromatography on silica gel eluting successively with $30 \%$ EtOAc -hexanes to provide $100 \mathrm{mg}(98 \%)$ of pure $32[\alpha]_{589}{ }^{20}+0.91^{\circ}\left(c 0.44, \mathrm{CHCl}_{3}\right) ;{ }^{1} \mathrm{H}$ NMR $\left(500 \mathrm{MHz}, \mathrm{CDCl}_{3}\right)$ \& 7.31-7.28 (m, $2 \mathrm{H}), 6.90-6.87(\mathrm{~m}, 2 \mathrm{H}), 4.62(\mathrm{~A}$ of $\mathrm{AB}, J=10.9 \mathrm{~Hz}, 1 \mathrm{H}), 4.53(\mathrm{~B}$ of $\mathrm{AB}, J=10.9 \mathrm{~Hz}$, 1H), $3.81(\mathrm{~s}, 3 \mathrm{H}), 3.60(\mathrm{dd}, J=5.6,5.6 \mathrm{~Hz}, 1 \mathrm{H}), 3.48(\mathrm{dd}, J=8.7,2.7 \mathrm{~Hz}, 1 \mathrm{H}), 2.73-2.64$ (m, 1H), 2.29-2.21 (m, 1H), 1.79, (d, $J=2.4 \mathrm{~Hz}, 3 \mathrm{H}), 1.28(\mathrm{~d}, J=6.8 \mathrm{~Hz}, 3 \mathrm{H}), 0.96(\mathrm{~d}, J$ $=7.0 \mathrm{~Hz}, 3 \mathrm{H}) ;{ }^{13} \mathrm{C}$ NMR $\left(126 \mathrm{MHz}, \mathrm{CDCl}_{3}\right) \delta$ 159.5, 130.9 129.7, 114.1, 83.3, 81.5, 77.7, 74.5, 66.5, 55.5, 38.7 29.8, 18.7, 10.9, 3.8; IR (thin film, NaCl) 3416, 2967, 2919, 2876, 1612, 1514, 1456, 1302, 1249, 1174, 1035, $825 \mathrm{~cm}^{-1}$; LRMS (EI, Na) calcd for $\mathrm{C}_{17} \mathrm{H}_{24} \mathrm{O}_{3}, 299.37 \mathrm{~m} / z(\mathrm{M}+\mathrm{Na})$; observed, $299.20(\mathrm{M}+\mathrm{Na})^{+} \mathrm{m} / \mathrm{z}$

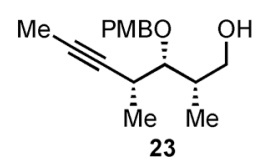

i) $n$-BuLi, $\mathrm{PhMe},-78^{\circ} \mathrm{C}$
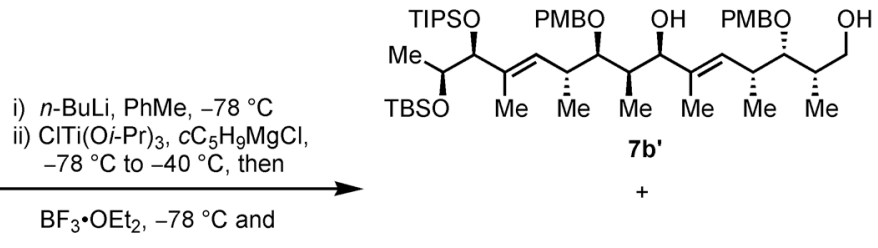

23
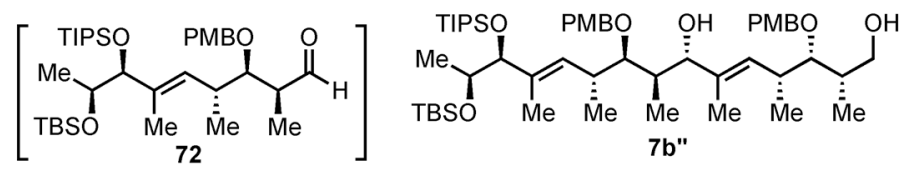

$77 \%$, r.s. $>20: 1$

\section{(E)-(2R,3R,4R,7S,8S)-3,9-di( $p$-methoxybenzyloxy)-13-(tri-isopropyl}

silanyloxy)-14-(tert-butyldimethylsilanyloxy)-2,4,6,8,10,12-hexamethylpentadec-

5,11-diene-1-ol. To a $-78{ }^{\circ} \mathrm{C}$ solution of alkyne $23(27 \mathrm{mg}, 0.097 \mathrm{mmol})$ in $0.97 \mathrm{~mL}$ of toluene, was added sequentially $n-\mathrm{BuLi}(2.5 \mathrm{M}$ in hexanes; $43 \mu \mathrm{L}, 0.11 \mathrm{mmol}), \mathrm{ClTi}(\mathrm{O} i$ $\mathrm{Pr}_{3}(1.0 \mathrm{M}$ in hexanes; $150 \mu \mathrm{L}, 0.15 \mathrm{mmol})$ and $c-\mathrm{C}_{5} \mathrm{H}_{9} \mathrm{MgCl}(2.0 \mathrm{M}$ in diethyl ether; $150 \mu \mathrm{L}, 0.30 \mathrm{mmol})$ in a dropwise manner via a dry gas-tight syringe. The resulting yellow solution was slowly warmed to $-40{ }^{\circ} \mathrm{C}$ and stirred for $2 \mathrm{~h}$ during which the reaction turned dark brown. The flask was then cooled to $-78^{\circ} \mathrm{C}$ and $\mathrm{BF}_{3} \cdot \mathrm{OEt}_{2}(32 \mu \mathrm{L}$, 
$0.25 \mathrm{mmol}$ ) was added in a dropwise manner. Following a stirring period of $10 \mathrm{~min}$ at $-78{ }^{\circ} \mathrm{C}$, aldehyde $72(20 \mathrm{mg}, 0.032 \mathrm{mmol})$ was then added as a solution in toluene $(0.1$ $\mathrm{mL}$ ) down the side of the flask via a gas tight syringe. The transfer was completed with additional toluene $(2 \times 0.1 \mathrm{~mL})$. Stirring was maintained for $1 \mathrm{~h}$ at $-78^{\circ} \mathrm{C}$, before the addition of saturated $\mathrm{NH}_{4} \mathrm{Cl}$ solution $(0.3 \mathrm{~mL})$. The suspension was allowed to reach ambient temperature before partitioning between $\operatorname{EtOAc}(5 \mathrm{~mL})$ and water $(3 \mathrm{~mL})$. The phases were separated and the aqueous layer was extracted with EtOAc $(3 \times 5 \mathrm{~mL})$. The combined organic layer was then washed with sat. $\mathrm{NaHCO}_{3}$ solution $(2 \times 10 \mathrm{~mL})$, brine $(1 \times 10 \mathrm{~mL})$ and dried over anhydrous $\mathrm{Na}_{2} \mathrm{SO}_{4}$. The crude material was purified by flash column chomatography eluting successively with $5 \%, 7 \%, 10 \%, 15 \%, 20 \%$ and $30 \%$ EtOAc/ hexanes to provide $22 \mathrm{mg}(77 \%)$ of $\mathbf{7 b}$ ' and $\mathbf{7 b}$ ” as the major regioisomer.

Regioiselectivity data for $\mathbf{7 b}$ ' and $\mathbf{7 b}$ ”. The residue obtained after a titanium reductive coupling as described above was filtered through a short pad of silica eluting successively with $5 \%(50 \mathrm{~mL}), 7 \%(50 \mathrm{~mL}), 10 \%(50 \mathrm{~mL})$ and $15 \%(50 \mathrm{~mL}) \mathrm{EtOAc} /$ hexanes until all traces of the partially reduced olefinic product of alkyne $\mathbf{2 3}$ were removed. All remaining organics were removed by washing the silica with $200 \mathrm{~mL}$ of $100 \%$ EtOAc. Analysis of the partially purified mixture by ${ }^{1} \mathrm{H}$ NMR shows a $\geq 20: 1$ mixture of regioisomers.

Data for major diastereomer $(E, E)-(2 S, 3 S, 4 R, 7 R, 8 R, 9 R, 10 R, 13 S, 14 S)-3-(p-$ methoxybenzyloxy)-7-(tri-isopropylsilanyloxy)-8-di(tert-butyldimethylsilanyloxy)2,4,6-trimethylnon-5-ene-1-ol, 7b'. $[\alpha]_{589}{ }^{20}+3.2^{\circ}\left(c\right.$ 1.25, $\left.\mathrm{CHCl}_{3}\right) ;{ }^{1} \mathrm{H} \mathrm{NMR}(400 \mathrm{MHz}$, $\left.\mathrm{CDCl}_{3}\right) \delta$ 7.31-7.26 (m, 4H), 6.89-6.86 (m, 4H), $5.65(\mathrm{~d}, J=9.4 \mathrm{~Hz}, 1 \mathrm{H}), 5.21(\mathrm{~d}, J=9.9$ $\mathrm{Hz}, 1 \mathrm{H}), 4.65(\mathrm{~A}$ of $\mathrm{AB}, J=11.0 \mathrm{~Hz}, 1 \mathrm{H}), 4.59(\mathrm{~A}$ of AB, $J=10.8 \mathrm{~Hz}, 1 \mathrm{H}), 4.55$ (B of 
$\mathrm{AB}, J=10.8 \mathrm{~Hz}, 1 \mathrm{H}), 4.51(\mathrm{~B}$ of $\mathrm{AB}, J=11.0 \mathrm{~Hz}, 1 \mathrm{H}), 4.15(\mathrm{~d}, J=4.0 \mathrm{~Hz}, 1 \mathrm{H}), 3.94-$ $3.88(\mathrm{~m}, 2 \mathrm{H}), 3.813(\mathrm{~s}, 3 \mathrm{H}), 3.809(\mathrm{~s}, 3 \mathrm{H}), 3.62(\mathrm{dd}, J=6.0,2.1 \mathrm{~Hz}, 1 \mathrm{H}), 3.58-3.57$ (m, 2H), $3.40(\mathrm{dd}, J=8.9,2.0 \mathrm{~Hz}, 1 \mathrm{H}), 2.88-2.80(\mathrm{~m}, 1 \mathrm{H}), 2.77-2.65(\mathrm{~m}, 1 \mathrm{H}), 2.02-1.92(\mathrm{~m}$, 1H), 1.90-1.79 (m, 1H), $1.72(\mathrm{~s}, 3 \mathrm{H}), 1.60(\mathrm{~s}, 3 \mathrm{H}), 1.11(\mathrm{~d}, J=6.6 \mathrm{~Hz}, 3 \mathrm{H}), 1.04(\mathrm{~s}, 21 \mathrm{H})$, $1.00(\mathrm{~d}, J=6.2 \mathrm{~Hz}, 3 \mathrm{H}), 0.96(\mathrm{~d}, J=6.9 \mathrm{~Hz}, 3 \mathrm{H}), 0.88-0.85(\mathrm{~m}, 12 \mathrm{H}), 0.83(\mathrm{~d}, J=8.1$

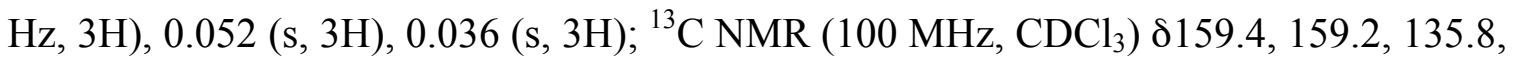
$134.1,131.4,131.1,130.9,129.7,129.6,129.3,114.0,113.9,84.3,83.6,80.6,79.2,77.4$, $74.9,73.0,66.5,55.5,38.8,37.5,36.2,35.2,26.1,18.8,18.42,18.36,18.2,17.8,15.8$, 12.6, 12.3, 11.6, 10.8, -4.35, -4.45; IR (thin film, $\mathrm{NaCl}) 3429,2957,2930,2866,1616$, 1514, 1457, 1249, 1104, 1039, 882, 827, $775 \mathrm{~cm}^{-1}$; LRMS (EI, Na) calcd for $\mathrm{C}_{52} \mathrm{H}_{90} \mathrm{O}_{8} \mathrm{Si}_{2}, 922.44 \mathrm{~m} / z(\mathrm{M}+\mathrm{Na})$; observed, $921.88(\mathrm{M}+\mathrm{Na})^{+} \mathrm{m} / z$.

Data for minor diastereomer $(E, E)-(2 S, 3 S, 4 R, 7 S, 8 R, 9 R, 10 R, 13 S, 14 S)-3-(p-$ methoxybenzyloxy)-7-(tri-isopropylsilanyloxy)-8-di(tert-butyldimethylsilanyloxy)2,4,6-trimethylnon-5-ene-1-ol, 7b" $[\alpha]_{589}{ }^{20}-10.8^{\circ}\left(c \quad 0.90, \mathrm{CHCl}_{3}\right) ;{ }^{1} \mathrm{H}$ NMR (500 $\left.\mathrm{MHz}, \mathrm{CDCl}_{3}\right) \delta$ 7.30-7.26 (m, 4H), 6.88-6.86 (m, 4H), $5.59(\mathrm{~d}, J=9.6 \mathrm{~Hz}, 1 \mathrm{H}), 5.31(\mathrm{~d}, J$ $=9.9 \mathrm{~Hz}, 1 \mathrm{H}), 4.76(\mathrm{~A}$ of $\mathrm{AB}, J=10.7 \mathrm{~Hz}, 1 \mathrm{H}), 4.59(\mathrm{~B}$ of $\mathrm{AB}, J=10.8 \mathrm{~Hz}, 1 \mathrm{H}), 4.54$ (B of $\mathrm{AB}, J=10.8 \mathrm{~Hz}, 1 \mathrm{H}), 4.43(\mathrm{~B}$ of $\mathrm{AB}, J=10.7 \mathrm{~Hz}, 1 \mathrm{H}), 4.16(\mathrm{~d}, J=4.2 \mathrm{~Hz}, 1 \mathrm{H})$, $4.08(\mathrm{~s}, 1 \mathrm{H}), 3.95-3.90(\mathrm{~m}, 1 \mathrm{H}), 3.809(\mathrm{~s}, 3 \mathrm{H}), 3.806(\mathrm{~s}, 3 \mathrm{H}), 3.82-3.75(\mathrm{~m}, 1 \mathrm{H}), 3.59$ (s br, 2H), $3.51(\mathrm{dd}, J=5.3,3.6 \mathrm{~Hz}, 1 \mathrm{H}), 3.42(\mathrm{~d}, J=8.6 \mathrm{~Hz}, 1 \mathrm{H}), 3.02-2.95(\mathrm{~m}, 2 \mathrm{H}), 2.76-$ $2.69(\mathrm{~m}, 1 \mathrm{H}), 1.99-1.86(\mathrm{~m}, 2 \mathrm{H}), 1.73(\mathrm{~d}, J=0.7 \mathrm{~Hz}, 3 \mathrm{H}), 1.54(\mathrm{~s}, 3 \mathrm{H}), 1.10(\mathrm{~d}, J=6.6$ $\mathrm{Hz}, 3 \mathrm{H}), 1.08-1.02(\mathrm{~m}, 24 \mathrm{H}), 0.99(\mathrm{~d}, J=6.2 \mathrm{~Hz}, 3 \mathrm{H}), 0.88-0.81(\mathrm{~m}, 15 \mathrm{H}), 0.060(\mathrm{~s}, 3 \mathrm{H})$, $0.043(\mathrm{~s}, 3 \mathrm{H}) ;{ }^{13} \mathrm{C} \mathrm{NMR}\left(126 \mathrm{MHz}, \mathrm{CDCl}_{3}\right) \delta 159.4,159.3,134.8,134.7,131.2,131.0$ $129.6,129.3,129.1,128.0,114.02,113.93,86.9,84.5,79.4,79.2,74.9,72.9,72.8,66.7$, 
$55.5,38.9,37.8,36.3,35.3,26.1,18.4,18.3,18.2,17.8,17.7,16.0,14.0,12.6,10.7,7.7$, $-4.37,-4.40$; IR (thin film, $\mathrm{NaCl}$ ) 3408, 2956, 2931, 2865, 1613, 1514, 1463, 1248, $1102,1039,883,825,775,680 \mathrm{~cm}^{-1}$; LRMS (EI, Na) calcd for $\mathrm{C}_{52} \mathrm{H}_{90} \mathrm{O}_{8} \mathrm{Si}_{2}, 922.44 \mathrm{~m} / \mathrm{z}$ $(\mathrm{M}+\mathrm{Na})$; observed, $922.93(\mathrm{M}+\mathrm{Na})^{+} \mathrm{m} / z$.

\section{References:}

1. Marshall, J. A.; Yanik, Y. M. Org. Lett. 2000, 2, 2173-2175.

2. Bahadoor, A.B.; Flyer, A.; Micalizio, G.C. J. Am. Chem. Soc. 2005, 127, 36943695. 